\title{
REVIEW OF SURFICIAL GEOLOGY AND ENGINEERING HAZARDS IN THE CANADIAN OFFSHORE
}

\author{
B.R. PELLETIER \\ Geological Survey of Canada, 601 Booth Street, Ottawa, Ontario, CANADA
}

\begin{abstract}
Surficial geological mapping and hydrographic charting is most complete in the Atlantic provinces offshore including the Gulf of St. Lawrence; secondarily, the British Columbia offshore and the Labrador shelf and slope are fairly well mapped and charted. However, the entire Arctic offshore has the poorest geological and hydrographic coverage of all Canadion marine waters, with the exceptions of Hudson Bay, Beaufort sea-Amondsen Gulf area and Lancaster Sound.
\end{abstract}

\begin{abstract}
For safe marine operations, enviromental information is required on winds, storms, waves, currents, tides and sea ice. This background is complemented by a seabed study designed to obtain grab and dredge samples of sediment or rock; to obtain sediment cores with the vibracorer, and gravity and piston corers; to obtain bedrock cores with the use of the diamond drill; to obtain bathymetric maps by means of sonic surveys in which echogroms reveal the topographic profile of the seafloor, and the side scan sonar give the areal view; to obtain details of bedrock features such as bedding, folds, faults, as well as distinguishing erosional and constmuctional topographic features all for the purposes of geological mapping; and to carry out visual sumeys remotely or directly by means of submersible equipment and vehicles. All these background data and survey results can have direct application to seabed engineering problems.
\end{abstract}

Potential hazards related to surficial geology in the canadian offshore affect engineering operations such as drilling, dredging, dromping coastal works, foundations and conchorages, cable lays, and pipelines. These hazards are grouped into five main categories: (I) erosion and sedimentation, (2) Morphology, (3) movement, (4) ground ice, and (5) sediments. A breakdown is given as follows: ice-scour grooves and ridges, current scour and fill, buried river channels, sand waves, megaflutes, sand bars, valleys, fjords, canyons, troughs, thermokarst, pingos, mud diapirs, pockmarks, scarps, terraces, hromocky terrain, stomp features, bedding dislocations, faulting, earthquakes, ice layers, icebonded sediments, thermal degradation, unstable substrate, hydrocorbons, organic matter, clathrates, hard (sand, boulders, bedrock) substrate, and moraine.

The geologist must provide information and advice on the natural fromework, and processes operating in the area; the engineer must appreciate these facts. But the engineer may be unable to re-locate his operational site; therefore, the geologist must present the information in its most complete and truest perspective in order to ensure a secure and successful operation.

\section{INTRODUCTION}

Surficial geological mapping and sampling of the seabed provides a basis for presenting and understanding engineering hazards that occur in the offshore. Such hazards include obstacles to the installing and securing of cable lays, pipelines, drilling operations, foundation sites, anchorage sites, shipping, aggregates, dredging, dumping, and coastal engineering works. To solve these problems of hazards, knowledge must be gained on the natural framework of a given area. This approach relies on a background of oceanographic and meteorologic information which includes the following parameters: waves, currents, tides, winds, storms, and ice. To complement the environmental study a sufficiently dense bottom-sampling program must be designed in which grab and dredge samples are obtained, and are augmented in depth by cores from the gravity or piston corer, the

$I_{\text {This paper was presented at the First Canadian }}$ Conference on Marine Geotechnical Engineering, Calgary, Alberta in April 1979. It is published here with the persmission of the Canadian Geotechnical society.
MARIIIME SEDIMEN'S, vol. 15, Nos. 2 and 3, August-December, 1979, pp.55-91 vibracorer, and the drill. In addition to the collecting of earth materials, sonic and seismic surveys must be carried out in order to broaden the areal view of the seafloor, and to extend our knowledge of geological features to given depths; the echosounder provides the topographic profile, and the side-scan sonar gives the broad areal presentation. By means of specially tuned sonic and seismic devices used at selected frequencies, it is possible to assess the reflectance character of sediments and thus gain some information on their nature. For example, some sediments such as clay are acoustically transparent at lower frequencies $(12.5 \mathrm{kHz})$ of the conventional echosounder (King 1967a). The same principle can be applied to the side-scan sonar although other aids such as photography, television or direct observation is required for periodic confirmation (Luternauer et al 1978).

Such features as valleys, pockmarks, icescoured grooves and ridges, sand waves, and various sediment types can commonly be distinguished by the use of these sonic instruments. However, it is the seismic profiler that reveals the depth of scour and sedimentation active in a given region, 


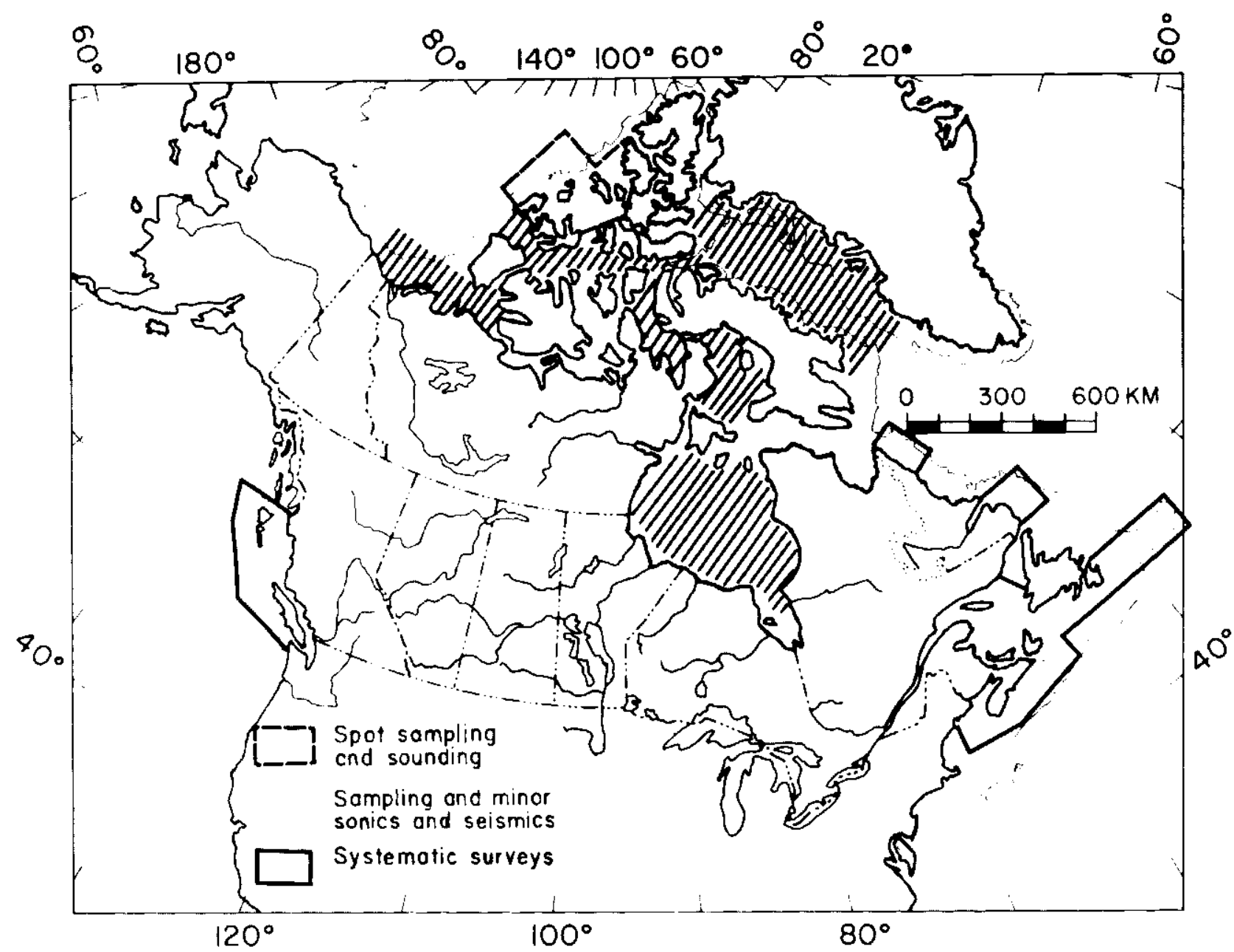

FIG. I Status of surficial geology coverage in the Canadian offshore. Certain oreas such as portions of Porry Sound, Becufort Sea and parts of Hudson Boy have hydrographic coverage equivalent to areas covered by the systematic surveys. (see Fig. 2).

it also distinguishes mounds of sediment that occur as moraines and submarine bars, and bedrock features such as faults, folds, domes, diapirs, unconformities and other structures. Therefore, because this profiling provides continuous records and sampling provides evidence of the geological units, a geological map can be produced from the results of this combined technology.

This methodology is inherent in the systematic geological surveys carried out in the Atlantic offshore particularly, and less so in the Arctic. The Pacific shelf and coastal area is fairly well covered seismically and hydrographically, and an abundance of bottom samples has been obtained in all areas. However, the production stage of geological maps, similar to that of the Atlantic offshore, has not been attained (Figs. 1 and 2 ). In the Arctic offshore, coverage by means of systematic surveying and sampling is the poorest. of all Canadian waters, with the possible exception of the Beaufort sea.

Other technologies are available to marine geologists in their efforts to produce geological maps of the seabed. Direct observations can be made by SCUBA divers and personnel aboard submersibles on the one hand, and by means of photography and underwater television on the other. The latter methods may be manual or remotely controlled. On both the manned and unmanned underwater vehicle (whether they are tethered or free-diving) remotesensing probes and sampling equipment may be installed to enhance further our observations of the seabed (Pelletier 1968, 1970, Blasco 1978). Indirect methods also exist for the purposes of observing both distribution and movement of sediments. The methodology embracing the greatest geographic scope is that which uses satellite imagery. In Minas Basin, Nova Scotia, Amos (1976, also Amos and Alfoldi 1979) used ground-truthing techniques, combined with a computer programed analysis of multispectral bands, to map the distribution and estimate the concentration of the sediment load for various phases of the tidal cycle. At all atmospheric levels, aircraft have been used as platforms for conventional aerial photography to depict distribution and movement of coastal and intra-tidal sediments. From a less distant vantage point, Long and Belanger (1978) used cameras mounted on a helium-filled balloon to observe sand transport in the intertidal zone of Minas Basin. At ground level, such devices as irradiated tracers and coloured beads distributed in sediment bodies, 


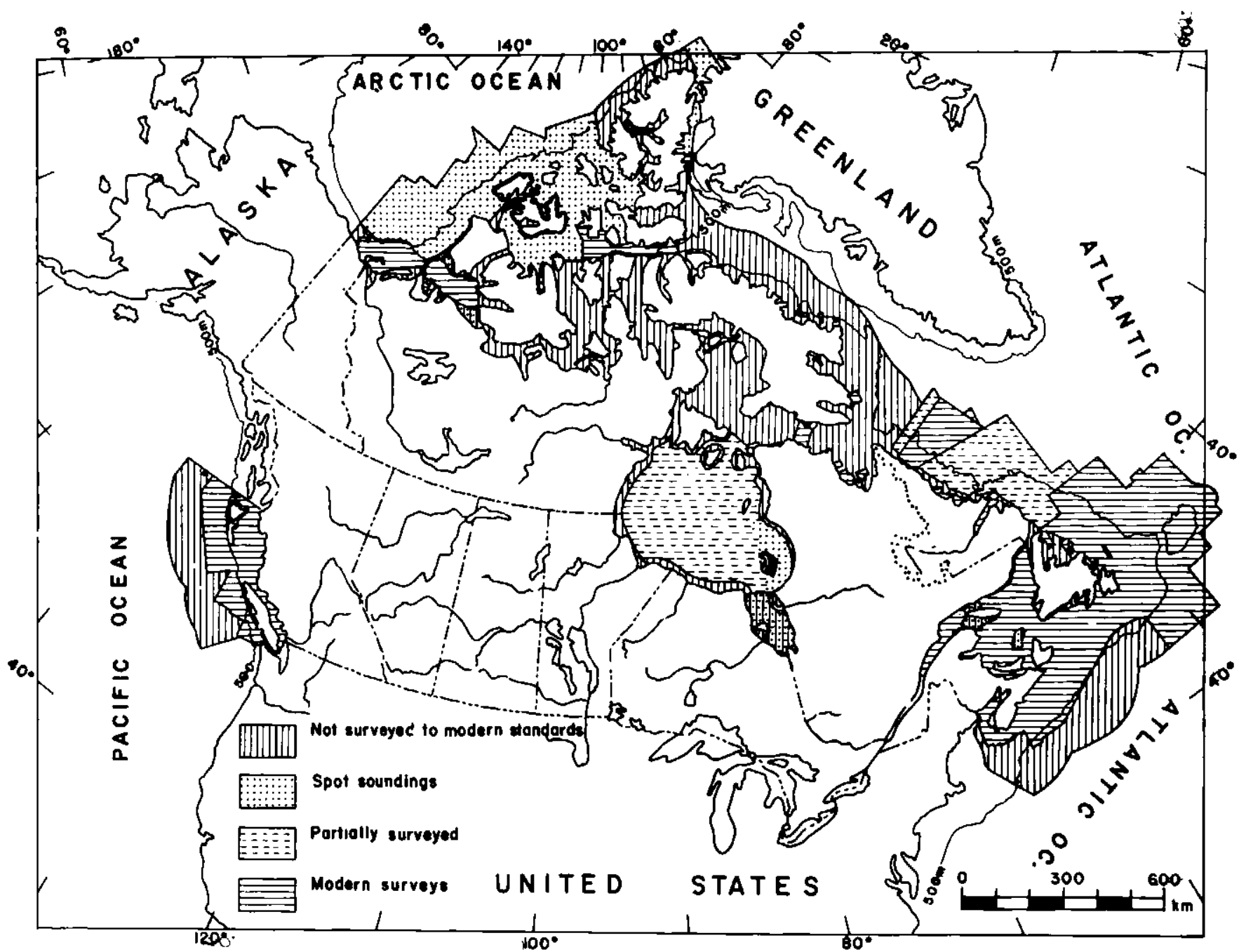

FIG. 2 Status of hydrographic coveroge. Nate the similarity of coverage for the geological surveys, due to production of the Natural Resource Maps of the Canadian Hydrographic Service. (Illustration modified from drawing, courtesy Canadian Hydrographic Service).

have been used for a number of years to detect and measure sediment movement and the volume transported (Bedford Institute of Oceanography, Dartmouth, Nova Scotia).

Geotechnical properties of unconsolidated sediments may be observed by indirect and nondestructive tests applied to the samples. For example, $\mathrm{X}$-radiography (Wahlgren and Lewis 1977) was applied to several Beaufort Sea cores to determine water volume and hence, indirectly estimate the bulk density of the sediment. As well, primary structures, pebbles and fossils were observed thus yielding considerable information on the nature and origin of the sediment. Neutron loggers have been used in borehole technology to determine porosity, as the amount of absorption is directly proportional to the porosity. Seismic refraction techniques will produce data on the velocity of sound through various materials and hence, by consulting well established relationships of this velocity and the density of the propagating media, it is possible to infer the type of material under investigation.

Finally, to aid the geologist and engineer, an enormous literature is available in the university and public domains, in the published accounts from the private sector and in numerous scientific and government publications. The latter refers to the publications of the Marine Sciences Branch (Fisheries and Ocean Affairs), the Geological Survey of Canada and the Earth Physics Branch. Canadian science publications such as the Canadian Journal of Earth Sciences are outlets for considerable private, industrial and government research in the offshore. In adition, numerous engineering journals serve the geotechnical professions. A publication covering coastal research in Canada is under preparation by S.B. MeCann and is based on papers given at the First National Conference on the Coastlines of Canada. Abstracts have been published in volume 14 , no. 1 of Maritime Sediments.

For the Pacific offshore, two substantial reference bibliographies on the geosciences have been compiled: one by clague et al (1977) consists of 873 entries cross-indexed by subjects and authors, and the other by Ricker $(1974,1975)$ contains 1850 references with location maps of the citations. Atlantic marine geology has been supported by the 


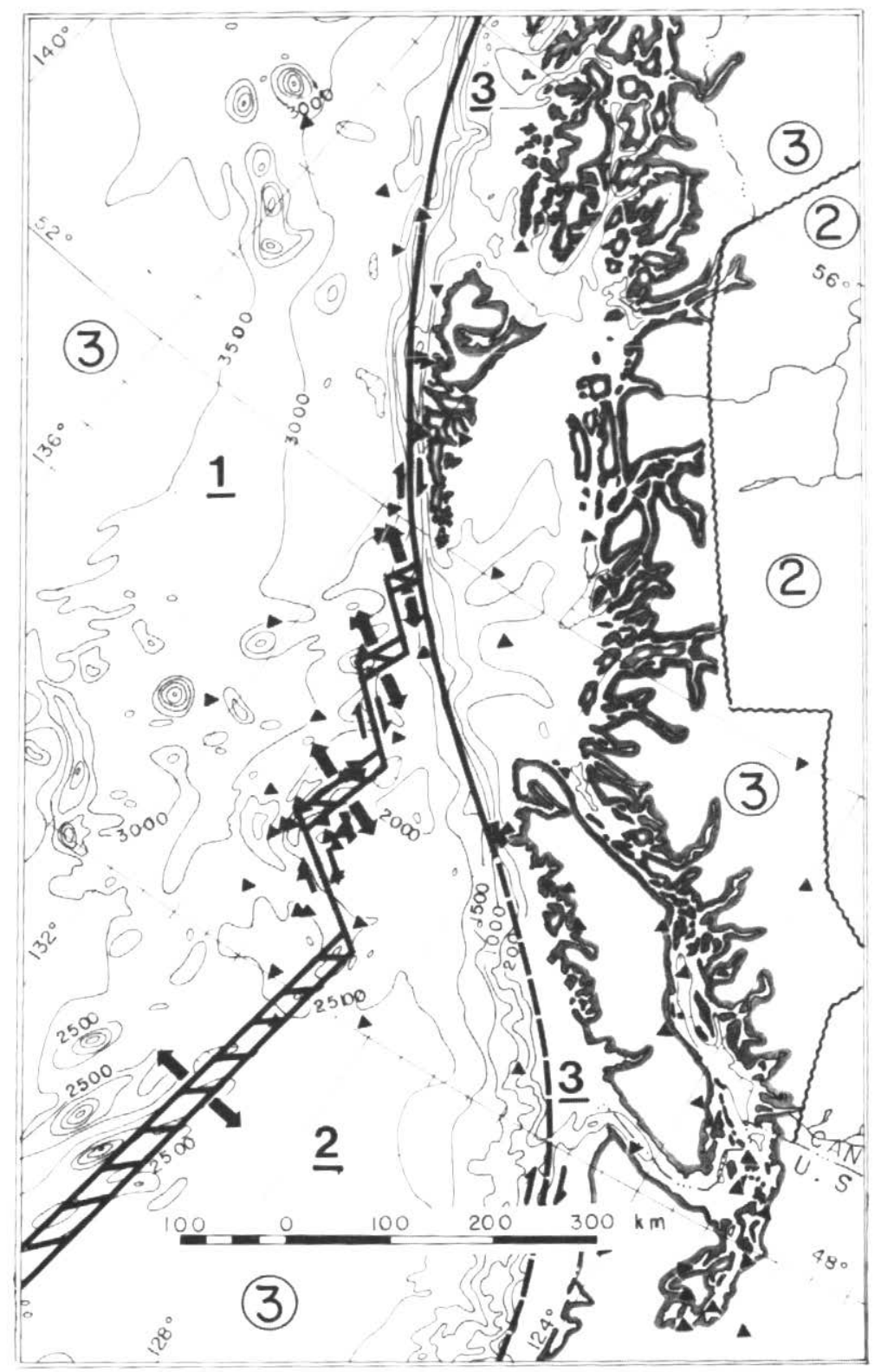

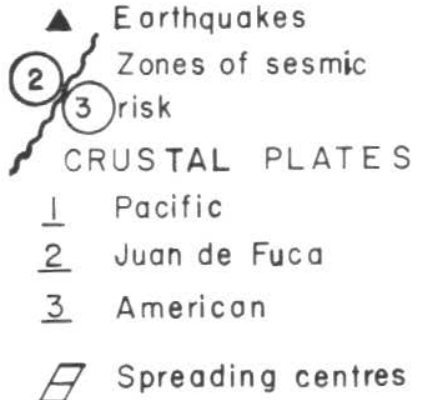

FIG. 3 Tectonic setting is based on movement of crustal plates. This controls topographic features and hence, sedimentation. Earthquakes result from this setting and may induce catastrophic movement of sediments. (Figure modified from Srivastava, 1971; and Milne et al, 1978). national publication outlets and specifically by several symposia volumes such as the Earth Science Symposium on Hudson Bay edited by P.J. Hood (1968) and the Earth Science Symposium on Offshore Eastern Canada, also edited by Hood (1971). Several papers by workers at the Bedford Institute of Oceanography (Geological Survey of Canada and the Marine Sciences Branch) comprise the review entitled: Offshore Geology of Eastern Canada; Volume 1 - Concepts and Applications of Environmental Marine Geology edited by Pelletier (1974) and Volume 2 - Regional Geology (edited by Van der Linden and Wade (1975). Two excellent summaries of eastern offshore geology are available: (1) N.J. McMillan (1973) for the northwestern Atlantic shelf and slope between Greenland-Baffin Island and Newfoundland and (2) D.A.V. Stow (1978) for the outer Scotian margin. Also, the Eastern Petroleum Operators Association is providing research and information on the Atlantic offshore and eastern Arctic.
Very few marine geological reviews are available for the Canadian Arctic Archipelago, probably because so little work has been carried out. However, some of this work may be found in the contributions of the Polar Continental Shelf Project, G.D. Hobson and J. Voyce $(1974,1975,1978$ ) and in an environmental statement on Lancaster Sound and vicinity by Milne and Smiley (1978). In an environmental atlas of the entire Canadian Arctic produced by Slaney and Associates and Fenco for Fisheries and Environment Canada (1978), many references to source materials are included. Two books of wider geographic and scientific scope dealing with oceanographic and geologic phenomena in the Arctic seas and basins were compiled by Sater (1963) and Herman (1974).

Numerous meetings have been held on the environmental and geological aspects of the southern Beaufort Sea region, under the auspices of Fisheries and Environment Canada together with the Arctic Petroleum 
Operators Association, Calgary, Alberta. The Beaufort Sea Profect under this dual promotion has published about 40 reports dealing with this research. Earlier, a symposium was held in San Francisco in 1973 and all papers were edited into a research volume by Reed and Sater (1974). Another symposium on the Beaufort Sea which focused on environmental geology and geophysics was held in vancouver, 1977 by the Geological Association of Canada. Abstracts were published in the Proceedings. A most recent addition to background material of the Beaufort Sea region is the manual for the protection and clean-up of shoreline oil spills prepared by B.W. Worbets of Canadian Marine Drilling, Calgary.

Supporting this entire canvass of geological and engineering productions is the superb contribution of the Canadian Hydrographic Service (Department of $\mathrm{F}$ isheries and the Enviromment). This work includes the 1:250,000 scale maps of the Beaufort Sea, considerable portions of the waters of the Archipelago, Baffin Bay, Hudson Bay and Janes Bay, Gulf of St. Lawrence and Bay of Fundy System and virtually the entire Atlantic and Pacific offshore to at least the $500 \mathrm{~m}$ isobath and commonly beyond. Another series on 1:1 000 000 scale is in production and covers greater areas where refined mapping is not required. Other contributions of the Canadian Hydrographic Service involve its comitment to the production of the so-called GEBCO sheets (General Bathymetric Charts of the Ocean). These charts will offer assistance to the engineer and geologist as exploration and development move progressively seaward to greater water depths.

A unique contribution regarding bathymetric representation is the three-dimensional profection of the Atlantic continental shelf, slope and rise between Newfoundland and Florida constructed by David Monahan (1971). This portrayal of the seafloor vividly displays relief, and permits longrange planning of geological survays and engineering projects. Maps of this type constructed at the proper scale should properly be the forerunner of any systematic investigation of the seabed. Failing that, a conventional bathymetric chart based on closely spaced soundings aided by a good navigational positioning system and the best .. 'otting scale available, should be used. Many geological features suspected as possible engineering hazards can be identified and located early, and a suitable program can be designed to overcome these obstacles.

In this paper a summary of the work in surficial geology is given for the Canadian offshore together with major engineering hazards related to the geology in each region. The final portion of the paper deals with the southern Beaufort Sea as a case history in which the environmental framework, sedimentary regime, and morphological development are presented as models in order to elucidate the engineering hazards present on the seafloor.

\section{THE BRITISH COLUMBIA OFFSHORE}

Most early scientific studies off the British Columbia coast dealt with physical oceanography and the fisheries. As human importance of the Fraser River delta grew, geological and engineering projects were directed toward it, and geological sampling programs commenced. The first of these was undertaken on the Fraser River delta by Johnston
(1921), and later by Mathews and Shepard (1962). In the intervening years, a geological description of the bottom sediments in the Strait of Georgia was given by Waldichuck (1953). Many workers in succeeding years at the University of British Columbia (Oceanography, Geology) contributed to the sedimentological studies of coastal and deltaic areas of British Columbia (Cockbain 1963, Tiffin 1969, Pharo 1972), while others concentrated on geological and geophysical programs in the adjacent shelf and marginal areas (Murray et al 1971, Murray and Tiffin 1969).

During the early 1960 's considerable interest in the newer theories of continental drift, plate tectonics and seafloor spreading (Fig. 3) encendered speculative notions on the origin of the British Columbia continental margin. In this decade, the petrolem industry commenced geophysical surveying and exploratory drilling of the British Columbia shelf. A description of the structural and stratigraphic framework of the west coast offshore was partly derived from this work (Shouldice, 1971).

While the geological work was proceeding, bathymetric charting was updated. A chart of the northeastern Pacific became available (McManus 1963), and consisted of bathymetric data compiled from earliex cruises. Another chart (Marmerick and Taylor 1971) was later drawn and served for years as the basis of geophysical studies of the adjacent abyssal areas of the Pacific coast of North America. However, the 1970 's became the International Decade of Ocean Exploration and, for the Canadian west coast, more maps with better positional control were required. Because of the urgent need for these maps, the Canadian Hydrographic Service commenced the production of a series of natural resources maps at a scale of 1:250 000 (Monahan 1977). These maps were to give magnetic, gravimetric, geologic as well as bathymetric coverage of the coastal and marginal areas of the shelf, and the adjacent slope and abyssal depths. In the interim, a bathymetric map of the west coast offshore was compiled by Tiffin and Seeman (1975). This map served to deineate the main submarine physiographic features of the area.

In the coastal zone, environmental information was needed so that geological studies took precedence in the following areas: the Fraser River delta (Kellerhals and Murray 1969, Luternauer 1972, 1975a, 1975b, 1976c, 1976d, 1977, Luternauer and Murray 1973); in Queen Charlotte Sound (Luternauer and Murray 1969, 1970, Luternauer 1972); in Skeena River delta (Luternauer 1976b, Clague 1978, Bornhold 1978); in Barkely Sound (Carter 1972); in general shelf-coastal areas (Bornholc 1978); in Georgia Strait (Tiffin 1969, Tiffin and Clagl? 1976, Clague 1975a, 1975b, 1976, 1977; Pharo and Ba:r :s 1976); and on general sea-level interpretations for the coastal area (Clague 1975c).

A pattern emerged from these studies that showed arenaceous sedimentation occurred in the inshore areas, succeeded by silt farther seaward, and finally by clay deposition in the outer fringes of the deltas and bottoms of basins. Luternauer (1977) in coring operations discovered rapid changes in deltaic formations progressing from sand to mudflats. occurrences of sand waves were recorded by means of side scan sonar over the deeper parts of delta front. Deltaic and other coastal environments were studied 
and distinguished by means of air photos from the standpoint of historical changes in morphology. drainage and vegetation (Medley and Luternauer 1976). Although sand complexes were indistinguishable the movement of hydrodynamic bed forms could be traced chronologically. This methodology is useful in planning engineering works in shallow, coastal waters.

Geological studies have been made recently in the mainland coastal waters and over the adjacent insular shelves of British columbia. In the southern strait of Georgia, seismic reflection profiles displayed complex geological structure due to tectonism, and a subdued topography in the deeper areas as a consequence of heavy sedimentation from the Fraser River (Tiffin 1969). Rugged topography characteristizes the northern portion of Georgia Strait where straight but steep canyons occur infilled with soft sediments (Clague 1976, Tiffin and $\mathrm{Claque}$ (1976). In the central portion, coarse sediments are found at the head of the basin, and fine deposits occupy the lower parts (Pharo and Barnes 1976). Southern Hecate Strait and western Queen Charlotte Sound are șimilarly covered, but sand and gravel comonly overlie a complex bedrock structure (Young and chase 1977). Bottom sampling in Barkely Sound (Carter 1972) revealed a relict sand and gravel cover over most of the shelf, except within basins and drowned river valleys where mud is prevalent. Milliman (1976) described angular gravels on the outer shelf and related them to erosion from nearby bedrock. Gravels inshore are more rounded, winnowed, and presumably are a glacial lag. The same phenomenon for gravels was observed off the west coast of Vancouver Island by yorath et al (1978), off Queen Charlotte Island by Tiffin et $a l$ (1978) and on Roberts Bank by Luternauer et al (1978).

Because of earthquake susceptibility along the British Columia margin, geophysical studies were initiated involving seismicity, gravity, magnetics and heat flow. These studies began in the late $1960^{\prime} \mathrm{s}$ and are continuing in all offshore areas (University of British Columbia, Earth Physics and Geological Survey of Canada branches, and Fisheries and Environment Canada). Exemplary studies are given by Srivastava et al (2971) on a wide range of geophysical activities carried out west of vancouver Island over the continental margin and adjacent abyssal areas. In this same region Srivastava (1971) interpreted magnetic and gravinetric data to determine the tectonic history of the British Columbia continental margin. Many other geophyslcal studies covered various parts of the continental margin as follows: in Toffino Basin west of Vancouver Island (Murray and Tiffin 1969); on the Queen Charlotte fault zone (Chase and Tiffin 1972); on the entire western continental margin (Chase et al, 1975), and various parts of the offshore (Tiffin 1969, 1972a, $1972 \mathrm{~b}, 1973,1974)$. Other Joint profects were carried out on the tectonism and stratigraphy of the west coast continental margin (Tiffin and Cameron 1972, Tiffin and Murray 1966, and Tiffin et al, 1971). All such studies as well as those on morphology, sedimentation, and glaciation are essential for as appreciation of engineering hazards on the northeastern Pacific continental shelf.

In the British Columbia offshore, most engineering hazards are related to three major sources: (1) seismicity, (2) topography, and (3) hydro- dynamic vigour. These factors present a sudden and dynamic situation which has no parallel elsewhere in Canadian waters. Many of the geological-geophysical phenomena are related directly to the presence of a so-called triple junction, produced by the intersection of three moving plates of the earth's crust (see Fig. 3 after Srivastava 1971, and Milne et al 1978). These movements have resulted in block faulting, folding, volcanism, rugged topography, and earthquakes. Locations of earthquake epicentres have been compiled by the Earth Physics Branch (Milne et al 1978), from which a map has been drawn illustrating earthquake distribution (Fig. 3). This is indeed necessary in determining zones of earthquake risks so that building codes can be established properly. Seismic shocks could also trigger submarine landslides, and effect great damage to seafloor installations. Related tsunamis may cause damage anywhere along the coast. Therefore, these occurrences must be noted, and precautions taken in view of buildings and coastal facilities susceptible to damage and destruction.

Topographic relief is striking in its remarkable variation across the coastal waterways between the mainland and outer islands, and again west of these islands to the edge of the continental margin and across the abrupt drop in the continental slope (Fig. 4). Bathymetric maps (Tiffin and Seeman 1975, Monahan 1977) indicate the very narrow continental shelf (.5 to $50 \mathrm{~km}$ wide) (Fig. 3), and the steep slope that falls from 200 to $2500 \mathrm{~m}$ over a few kilometres of horizontal distance. Across the continental margin, topography is extremely rough in areas of bedrock exposure. On a small scale, such as observed from submersible operations (Yorath et al 1977), near-vertical and rugged bedrock ledges several metres high may be present. This rapid change in topography may cause problems in the matter of suspended installations; seafloor crossings of pipelines and cables may be inhibited.

Along construction courses lying in parallel configuration with the north-south trends of the shelf and geological features such as ledges and troughs, the grain of the bedrock structure may permit easy installing of pipelines and cables. This advantage may extend to portions of the slope, particularly where troughs are infilled with mechanically stable sediments or, possibly, ancient and inactive slumps. Similarly, many submarine canyons (Herzer 1978) are no longer active in terms of mass movement of sediments, and may be utilized as routes for seafloor crossings. However, the mapping by Herzer (1978) off the Pacific shelf, revealed hazardous topography and catastrophic transport of consolidated sediments. This latter phenomenon actually comprises a crustal dislocation as it involved block movement and slumping.

In the submarine canyons lying west of the outer islands, the spectacular change in topography together with mass movement of unconsolidated sediment has created massive infilling. Some of these processes may be modern, but many are ancient and quiescent. Therefore an inspection by means of camera, television, or directly in a submersible is required - together with sampling and seismic surveying - before utilizing these sites for engineering works.

Seafloor topography is actually bedrock topography in approximately 10 percent of the shelf 


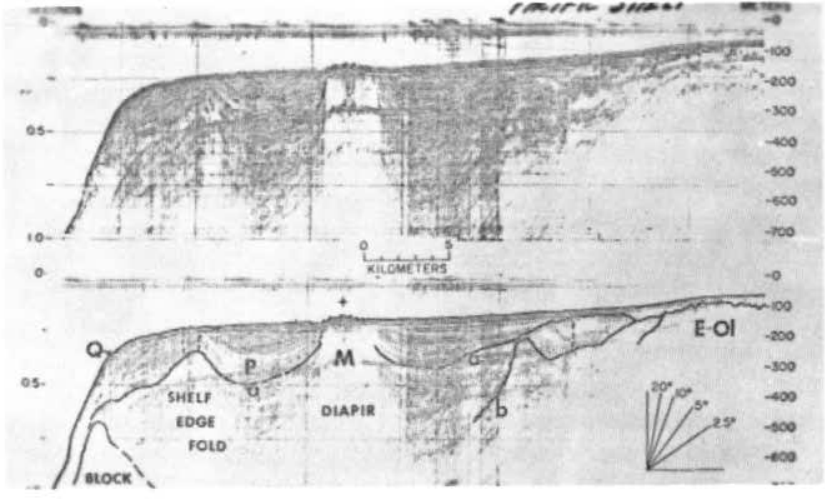

FIG. 4 Seismic reflection profile across Pacific Shelf. Complex structure and steep continental slope are displayed, as well as outcrop belt near central portion of shelf. (Courtesy of D.L. Tiffin, Geological Survey of. Canada).

area (B. Bornhold, pers. comm.); thus, engineering difficulties may arise in traversing from bedrock to unconsolidated sediments. Where bedrock is present though, good footings can be maintained but the same may not hold for substrates of soft, unconsolidated sediments. Yet the latter feature may be amenable to seafloor ploughing operations. One of the greatest threats to engineering projects is the occurrence of a large ocean swell. This swell may produce an undesirable sea state for surface operations, but it also generates waves of high orbital velocities that propogate hydrodynamic energy directly to the seabed. This translation of energy is manifested in the production of large oscillatory sand and gravel waves on the seabed in water depths to $104 \mathrm{~m}$ (Fig. 5). These were observed from the submersible PISCES IV (Yorath et al 1978, 1979) off Vancouver Island. Sand waves were recorded at depths of $285 \mathrm{~m}$ in Johnstone Strait, in $65 \mathrm{~m}$ on Amphitrite Bank off the southwest coast of Vancouver Island, and in 80 to $90 \mathrm{~m}$ over the Fraser River delta (Luternauer et al 1978). Such responsible wave energy would present the double hazard of scouring and burial to any installations laid on the seabed.

In certain areas of the shelf, bottom currents continually scour the seabed so that bedrock is exposed. Thus, a hydrodynamically active shelf is present adjacent to the western coasts of the offshore islands. Here a considerable transport of sediment is taking place continuously. The occurrences of scour and burial present a hazard to engineering construction involving pipelines, cables and footings.

Inshore in the passages such as Georges Strait and Seymour Passage, tidal currents may induce similar effects as wave-generated or oceanic currents. Velocities of currents in these areas may exceed $400 \mathrm{~cm} / \mathrm{s}$. Closer inshore, coastal erosion may be accelerated by tsunamis, wave action and longshore currents. Both alongshore and offshore, marine erosion and sedimentation present sequential and separate problems of undercutting by means of scour, and burial by means of sediment transport.

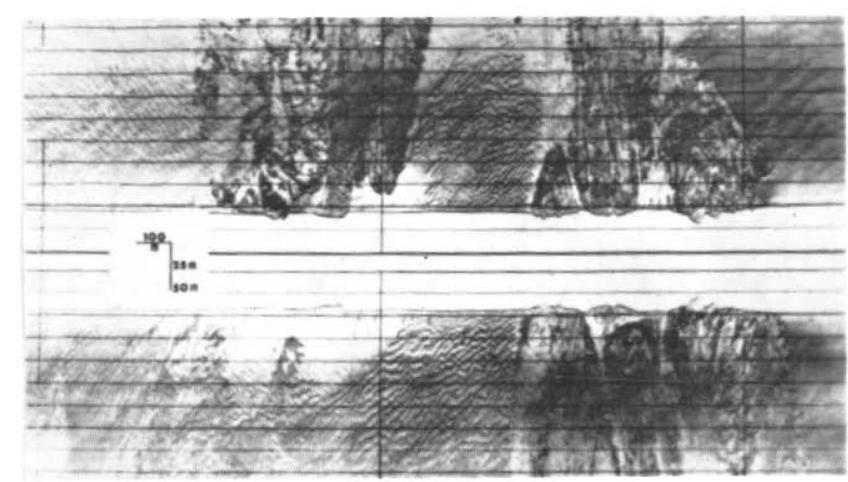

FIG. 5 Side scan sonargraph of sand waves and bedrock on continental shelf west of Vancouver Island. Water depth is about $100 \mathrm{~m}$. (Courtesy of B. Bornhold, Geological Survey of Canada).

Although the glaciers of today present no obvious threat to engineering practices in the British Columbia offshore, their Pleistocene counterparts have left a legacy of dangers and direct causes of modern disasters affecting engineering works. Thick moraines are still present over the inshore shelves which could render drilling and excavations difficult. Valleys have been overdeepened and considerable glacial debris is available for subsequent and sudden movement to the valley floors. Because these floors are those of fiords, submarine landslides are a real hazard in these coastal areas. Some have already occurred, such as the slope failure at Kitimat Arm, British Columbia (Luternauer 1978, Swan 1979).

Although it was post-event, a combined field study of the Kitimat slide was conducted involving a side scan sonar survey (Luternauer and Swan 1978) and shallow seismic reflection profiling (Bornhold 1977) in order to determine the internal structure and volume of the slide. In the course of the survey an older, possibly inactive slide was discovered thus introducing a reasonable methodology for examining the nature and potentialities of such features. As well, bedrock was observed in shallow areas and it became apparent that safe navigation routes could be established by avoiding such obstructions. The fiords, because of bedrock exposures and extreme variations in topography, represent numerous potential hazards to engineering construction. As an engineering safeguard, these areas should be surveyed thoroughly by sonic, seismic and coring methods. But at least equally important, studies and tests should be conducted on the geotechnical properties of the unconsolidated sediments occurring at the fiord heads, and along the upper slopes of their steep margins before installing commercial and cultural facilities. This may circurnvent the disastrous consequences arising from naturally occurring phenomena. Many canyons lying in fiord terrain are receiving vast accumulations of muds that are generated by landslides.

Lying adjacent to the fiord coasts, the inshore coastal basins are characterized by considerable sedimentary infilling. The thickness of these 
sediments and their depth of occurrence are strongly correlated (Clague 1975a). For example gravels, sands and coarse silts are found on ridges and banks, whereas fine silts and clays are deposited in the submarine hollows. Similar observations were made from investigations carried out in southern Georgia Strait (Pharo and Barnes 1976). Mostly the sediments are derived from coastal and shallow submarine bluffs consisting of unconsolidated sediments. In addition streams and rivers are local suppliers (Clague 1975b). Seismic reflection profiles indicate the presence of such local troughs (Clague 1976), therefore, routes lying parallel with the longitudinal axis of these basins could serve as excellent sites for seafloor crossings. Across the basins, however, extreme relief formed inmediately of bedrock would present a difficult situation for construction of any kind.

\section{THE ATLANTIC PROVINCES OFFSHORE}

Systematic surveys embracing bottom sampling together with sonic and seismic surveys have been carried out over most of the continental shelf off Atlantic Canada. The earliest systematic survey of surficial marine geology was undertaken by L.H. King (1967b) over the Scotian Shelf in an area adjacent to Halifax, Nova Scotia and Sable Island, at the edge of the shelf. However, before producing this map King (1967a) developed a methodology which is still in use today, and has only been improved with the use of more refined seismic technology, like that of the Huntec Deep Tow Sytem (King and Fader 1976), and various side-scan sonar systems such as the EGG, Klein, and AOL (Atlantic Oceanographic Laboratory, Dartmouth, Nova Scotia) instruments. With the use of the Kelvin 26B echosounder, King was able to distinguish different sediment types from analysis of the echogram. These sediments were sampled and their locations plotted so that with the aid of both sonic and, later, seismic profiling, geological cross-sections and maps were produced. King (1970a) described many units as follows: (1) Sable Island sand and gravel, (2) LaHave clay, (3) Sambro sand, (4) Emerald silt, and (5) Scotian Shelf drift. As well, he discovered the existence of numerous offshore glacial moraines (King 1969), submerged river systems, and recent pockmarks (King and MacLean 1970b) (Fig. 6). In a period beginning from 1965 to the present, King and his colleagues have produced an impressive series of maps: on the Yarmouth - Browns Bank area (Drapeau and King 1972), on a comprehensive account of the endmoraine complex on the Scotian Shelf (King, MacLean, and Drapeau 1972), on the surficial geology of the Banquereau and Misaine Banks (MacLean and King 1971), on the geology of the Scotian Shelf (King and MacLean 1976), on the surficial geology of Canso Bank and adjacent areas (MacLean, Fader and King 1977) and on the geology of the Bay of Fundy and Gulf of Maine (Fader, King and MacLean 1978). In the geological studies, Tertiary and older rocks were sampled (King and MacLean 1970a) and mapped seismically so that a series of geological crosssections and maps were drawn. Features such as the Glooscap fault were identified together with suspected occurrences of salt domes at depth. Many of these geological and surficial features are now being observed and traced into adjacent
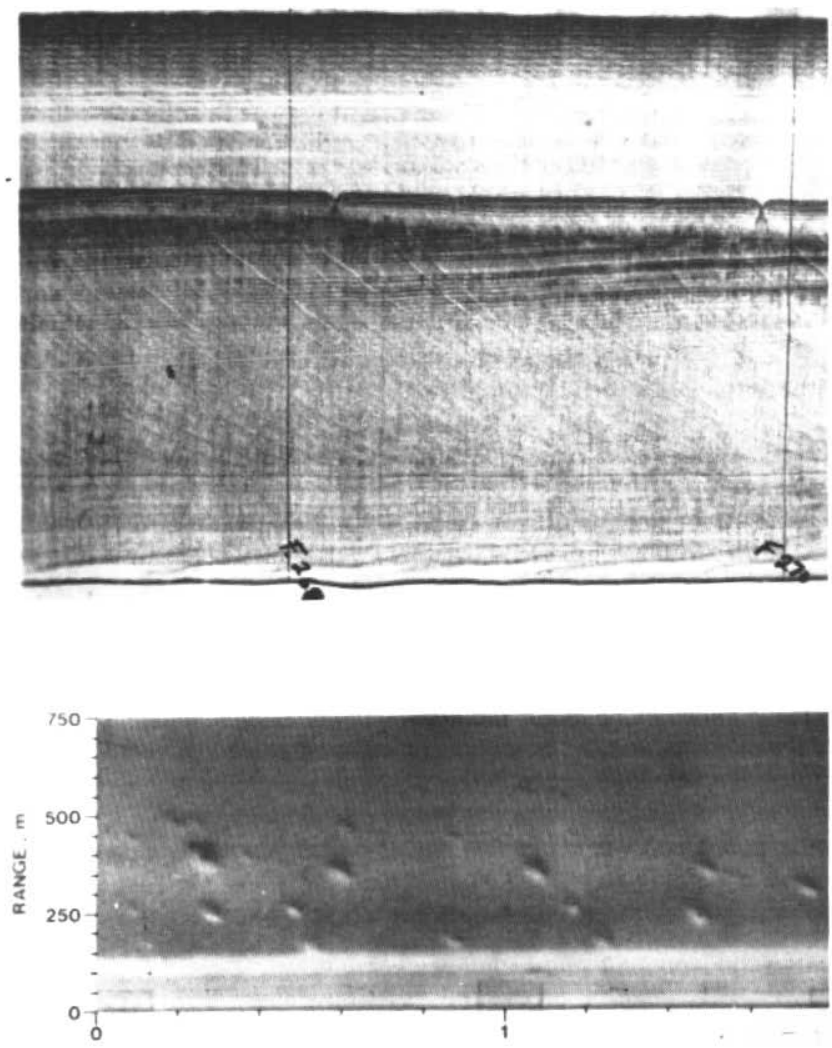

FIG. 6 Seismic reflection profile (upper) and side scan sonargraph (lower panel) showing occurrence of pockmarks on the Scotian Shelf. Orientation of pockmarks due to current flow. Recorded by courtesy of L.H. King, Geological Survey of Canada, B.I.O., Dartmouth, Nova Scotia.

areas.

On the Scotian Shelf, King (1979) described numerous geological features that would present obstacles to engineering and bottom installations. These include depositional features such as sand bodies and moraines, erosional features such as ice-gouged furrows and gullies, structural features such as faults, and prominent physiographic features such as cuestas and terraces. Sand waves occur in the vicinity of Sable Island and offshore southwestern Nova Scotia. A study of their form and movement, and their relationship to currents is given by Ruffman et al (1978). Drapeau (1970) observed giant sand waves over Browns Bank. These waves are also present on the southwestern Grand Banks of Newfoundland and some have been identified as megaflutes, particularly in the area of Placentia Bay. These constructional features are subfect to movement and thus would endanger the security of seabed installations in the vicinity. Because their origins, or movement is derived from high-velocity bottom currents, a double danger is imposed: (1) by scouring, in that material surrounding an installation is eroded and a support removed, and (2) by burial, in that eroded sediments may tend to bury an engineering facility, pipe, or cable. A danger to shallow footings and seafloor rigs could also exist. 


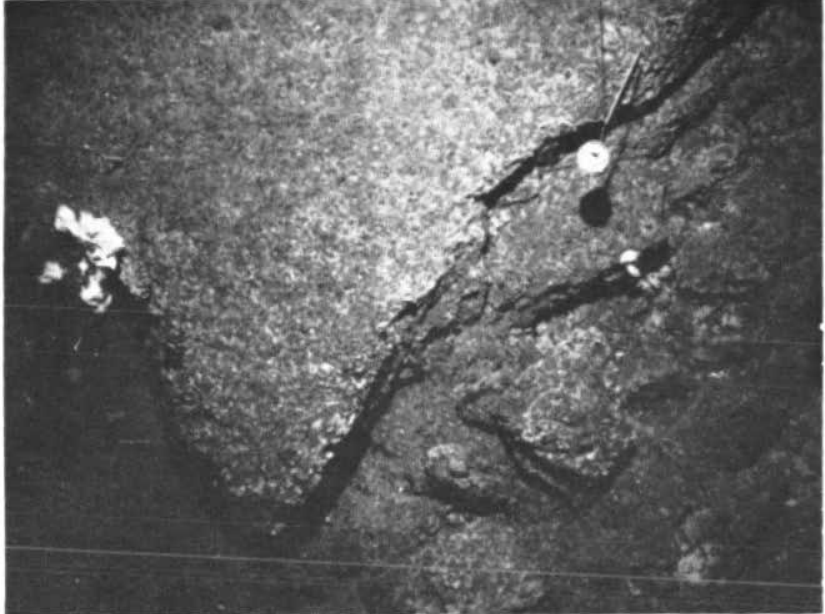

FIG. 7 Ledges of Tertiary siltstone at $4000 \mathrm{~m}$ depth in The Gully, $50 \mathrm{kms}$ east of Sable Island, Nova Scotia. (Photo from B.I.O., Dartmouth, Nova Scotia). (Marlowe, 1967, 1969).

On the seafloor of Placentia Bay, Newfoundland King (1979) has identified erosional features which he has termed megaflutes. Because these scour features are indicative of strong erosional currents, they could present a risk to engineering installations and other facilities placed on the seafloor. This situation is endangered additionally by the prospect of abrupt changes in topography, perhaps in the magnitude of a few metres over short distances in the immediate vicinity of the megaflute field. These scours could also present problems in that local changes in seabed material are companion and concurrent phenomena.

Submarine terraces are displayed as nickpoints in the topographic profiling record, and by changes in seabed material. The latter may also include exposures of bedrock, and this, together with a sudden change in bottom slope could be troublesome to engineering operations like pipelaying.

A change in sediment type due either to a change in the hydrodynamic environment, bathymetry or topography could present either an engineering hazard or an advantage. On the one hand, soft sediments could easily be ploughed or jetted but would present a poor foundation for man-made structures. On the other hand a firm bottom, possibly bedrock, could enhance foundation applications but complicate construction of pipelines or cable lays.

Buried valleys infilled with soft silt would promote the prospects for burying pipes and cables, but afford poor opportunities for foundations. These valleys occurring in a dendriditic system abound over the Scotian Shelf, particularly the middle and inner portions. They are mainly extentions of present drainage systems that were cut subaerially in earlier times. Some originated in the Tertiary and late Mesozoic, and show evidence of over-deepening due to Pleistocene glacial erosion.

Submarine canyons such as the Gully, lying east of Sable Island at the edge of the shelf, may be sites of submarine erosion and bedrock ledges (Fig. 7). Turbidity currents and the funnelling of sediments at the headward portion of the canyons may constitute processes hazardous to engineering activities. Unpredictable currents may arise in these vicinities thereby causing changes in the sedimentational pattern and possibly inducing other hazards. Older canyons may be infilled (King 1979) and this may yield anomalous thicknesses in the sedimentary column over short distances.

Fjord-like features, similar to the Laurentian Channel and its tributaries, have over-deepened valleys and steep topographic profiles which may inhibit drilling and the installation of structures that cross an otherwise regular, shallow shelf. But as in the case of drowned and infilled valleys, the fjordsare repositories of fine sediments mainly, and thus suitable for pipe and cable lays. Pockmarks originally discovered and described by King and MacLean (1970b) presumably developed by the pressure of escaping water or gas in the seabed. Bottom currents would transport fine sediments thus thrown into suspension from about $6 \mathrm{~m}$ into the seabed and leave an elongated elliptical plan (85 $\mathrm{m}$ in diameter) over the excavation, and aligned parallel with the current (Fig. 6). These conical pits may produce an unstable sea bottom, particularly where active. This situation presents an immediate foundation problem which may only be overcome by avoidance.

Iceberg furrows carved by ice keels dragging the sea bottom form an obstacle for the engineers who must place installations on the seafloor. Many furrows on the eastern Scotian Shelf and Grand Banks are relict (King 1976), as shown by sediment fill and subdued profiles. Those that are recent present a hazard with respect to seafloor engineering. These features must be mapped by means of sidescan sonar, and their topographic profiles studied from high-resolution echograms. When their distribution is known, an estimate of the return rate of scouring may be determined. Possibly areas free of such engineering hazards may be delineated.

Sediments play an important role in site selection for engineering works and drilling. Moraines contain bouldery material which could seriously impede drilling activity. This problem may be more grevious over the northern shelves of Canada, but it is significant over the Scotian Shelf because of the wide extent of the moraine in prospective areas of exploration. Some finer sedimentary bodies contain gas and, if under pressure, represent an extremely hazardous drilling situation. Organic content in stiff clays has enhanced the sitffness of the clay, according to Rashid and Brown (1975), which may result in an over-consolidated clay and hence a more stable bottom.

Structural and tectonic factors include faults, earthquakes, and shallow salt domes all of which menace engineering works because of potential movement and ultimate dislocation. An unconsolidated deposit is potentially unstable and could induce slumping, submarine landslides, turbidity currents, or severe dislocation of the seabed and its contained geological formations. In order to address the instability problem, regional mapping must first be carried out in vicinities suspected of possible bottom or crustal movement.

Apart from these surveys, numerous bottom sampling programs were carried out over the Scotian 


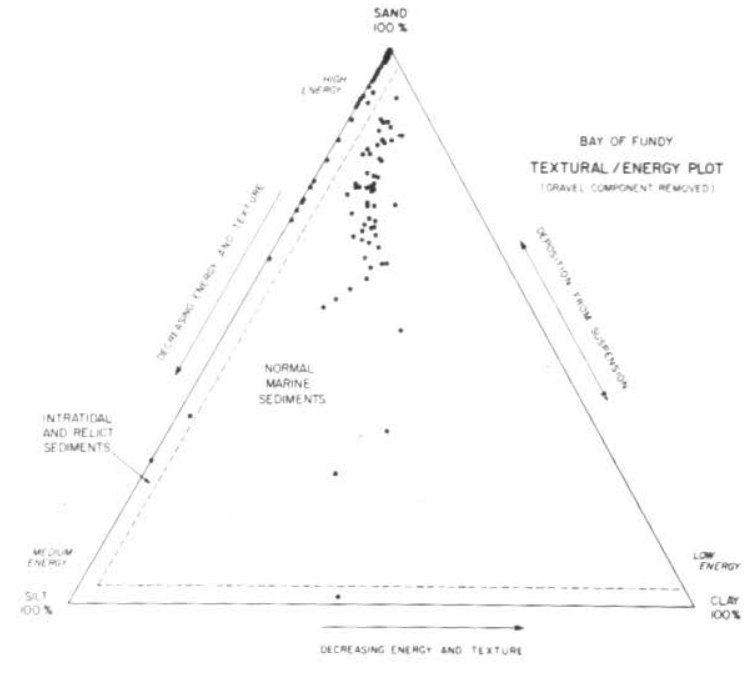

Shelf by workers at Dalhousie University, Halifax and the Bedford Institute of Oceanography, Dartmouth. A history of these contributions is given by Stow (1978) who describes the distribution and composition of sediments along the outer scotian margin. He also draws a fairly lucid model on the development of submarine morphology, sedimentary bodies and their relationship to glaciation and its effects on the scotian shelf. Included is a model on Holocene oceanographic circulation for the region. Stow has inferred that material derived from glaciers and ice-rafting lies at the edge of the shelf where it is re-worked by bottom currents. Sands are re-suspended and move downslope and this latter process may be accompanied or enhanced by slumping on the upper slope and the subsequent generation of turbidity flows to the sediment fans at the base of the slope, and on the continental rise. Piper (1975) had previously suggested turbidity flows as indeed had King and Young (1977). This depositional mechanism and the attendant bottom dislocation presents a hazard to the laying of cables, pipes, bottom installations and drilling operations. It would be necessary to examine the slumped features to determine their degree of stability and this may be accomplished by means of side scan sonar, profiling, photography, underwater television, and direct or remote viewing from a submersible.

In the Bay of Fundy, many sampling programs were carried out with emphasis placed on the distribution and origin of bottom sediments. Swift et al $(1966,1967)$ working in Minas Basin showed this distribution and its relation to bottom and coastal erosion, and the tidal regime. These studies were followed by more specific investigations of intertidal sand bodies (Swift and McMullen 1968). To the west, Swift et al $(1969,1973)$ completed a study on the bottom sediments of the Bay of Fundy, mostly the offshore area, and plotted their distribution with regard to textural types. Glacial lag as well as marine sediments were recognized. Later Pelletier (1974) related the distribution of these deposits to hydrodynamic vigour. A textural ternary diagram served as a model upon which to base the interpretations of depositional trends (Fig. 8). Inferred from these models are the areas of quiet deposition which are characterized by low hydrodynamic vigour and fine deposits and, as such, are suitable locations for cable lays and pipelines.
FIG. 8 Ternary textural diagram illustrating energy zones of sedimentation. Note the normal marine component in centre, and the intratidal and relect zone on the siltsand side. Here sediments are in hydrodynamic equilibrium with their depositional environment, at least, or more energy is available than required to maintain their occurrence in those environments as shown by their plotted positions in the diagram. (Pelletier, 1974).

FIG. 9 Current meter in Avon River estuary near Minas Basin, Nova Scotia, buried by advancing sand waves. (Courtesy R.J. Knight, Petro Canada Ltd)

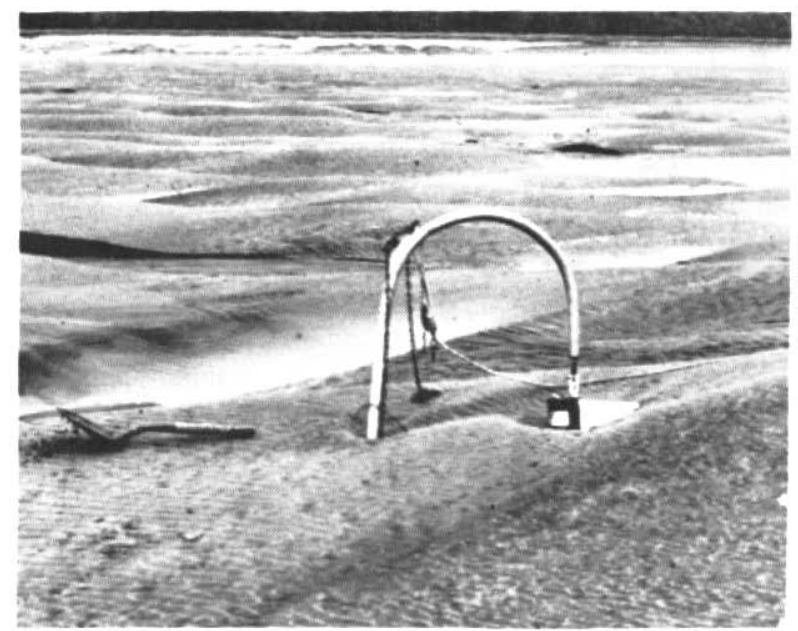

These areas can easily be distinguished from those of vigorous scour and coarse sediment deposition, which would prove hazardous to bottom installations. At the headward portion of the Bay of Fundy in Minas Basin, several workers have carried out studies on the distribution and origin of bottom and intertidal sediments. Swift et al (1967) working in Minas Basin showed this distribution and its relation to bottom and coastal erosion, and the tidal regime. These studies were followed by more specific investigations of intertidal sand bodies (Fig. 9) (Swift and McMullen 1973, Dalrymple 1978, Knight 1977, Amos 1976, 1978, Amos and Joice 1977, Amog and Long 1978, Long 1978, Amos and Asprey 1979). All workers show the environmental and sedimentary regime and the problems posed to damsite engineers, but not all are agreed on the major influences such as retreat of the shoreline and the excessive sedimentation that would lead eventually to silting of the basin. This possible drastic effect is partly exemplified by the recent construction of a causeway over the Avon River near Windsor, Nova Scotia where $8 \mathrm{~m}$ of mud accumulated in a period of approximately 18 months. This muddy deposit is extending downstream toward Minas Basin (Patton 1976). Such a process would have early consequences on submerged hydro structures in Minas Basin. 

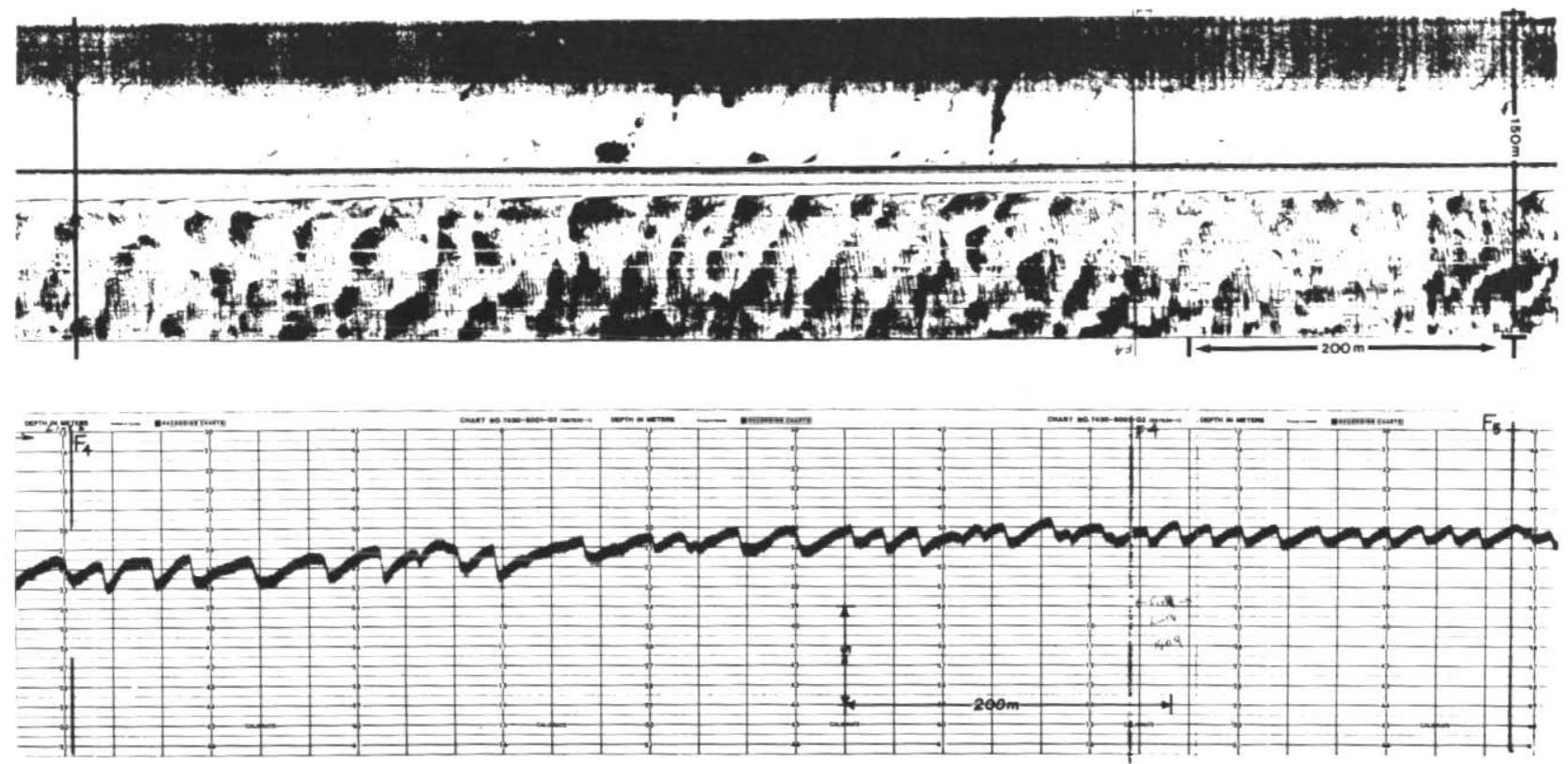

FIG. 10 Sand waves in Miramichi Estuary. Upper panel shows plan of waves on side scan sonargraph; lower panel shows cross-section wave on echogram. (Courtesy of G. Reinson, Geological Survey of Canada).

Systematic surveys were undertaken by Kranck (1967, 1971) in Northumberland Strait, and by Loring (1962, 1965, 1967, 1972, 1975) and by Loring and Nota (1966, 1973) in the Gulf of St. Lawrence. Kranck also produced works on sedimentology and morphological development in Northumberland Strait (1972a, b) and Loring (1963), together with Nota (Nota and Loring 1964, Loring and Nota 1968, 1969) carried out considerable work on the inorganic fractions of the Gulf sediments. A side scan survey was conducted over some of the Gulf of St. Lawrence and various sedimentary environments were distinguished (Loring et al 1970), particularly those exhibiting sand waves. These latter areas over the southern banks are swept by bottom currents and are the sites of considerable scour and hence would be unsatisfactory for the laying of bottom installations. The same situation may hold for the Magdalen Islands where considerable movement of sand is taking place that is directly related to coastal erosion (Owens 1974). This aspect of sediment transport and depositton, together with tidal action is responstble for the construction of sand waves (Fig. 10) In the Miramichi estuary (Reinson 1976a,b, 1977).

A multidisciplinary survey by a team of scientists and technicians from the Geological Survey of Canada (Atlantic Geoscience Centre) at the Bedford Institute of Oceanography, Dartmouth, worked on problems of oil spill and industrial pollution in Canso strait and Chedabucto Bay, Nova Scotia (Buckley et al 1974). They discovered differences in fauna from those in unpolluted areas, an accumulation of industrial waste in the submarine sediments, and irreversible retreat of low-energy beaches where oil-covered sediments were removed as part of a clean-up operation.

Engineers must be alerted to such problems, particularly in environmentally sensitive areas where these hazards could arise. Also on this project, R. Brown of Nova Scotia Technical College carried out geotechnical engineering studies on the marine sediments (Fig. 11).

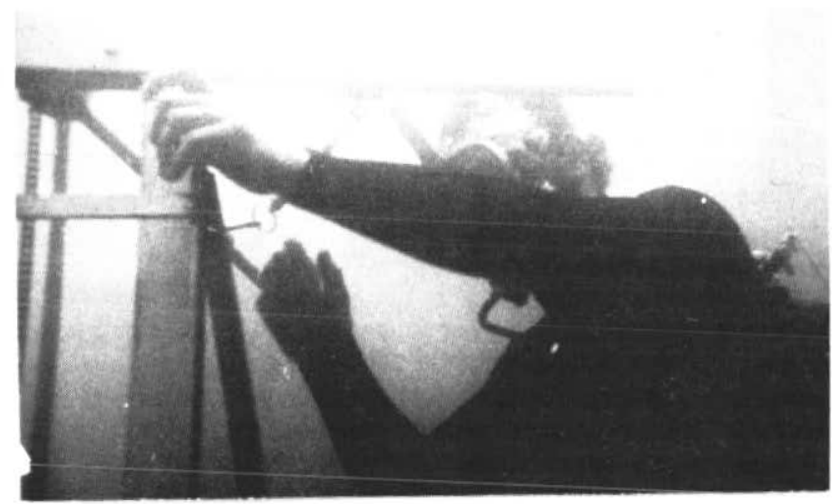

FIG. 11 Diver operating in situshearvane equipment for geotechnical testing of the substrate $(1.5 \mathrm{~m})$ in Canso Strait. Measurements by R. Brown, Nova Scotia Technical College. (Photo by R. Belanger, Bedford Institute of Oceanography, Dartmouth, Nova Scotia.)

Another engineering hazard lies in the fjords of the Laurentian Channel and its tributaries, particularly in the northeastern Gulf. In this area Shearer (1971) carried out a seismic reflection survey and showed the occurrence of moraines and Vshaped notches cut in the seafloor. He compared these notches with the pockmarks discovered earlier by King and MacLean (1970b) on the Scotian Shelf. However, no side scan survey was carried out so the pockmark designation remains unconfirmed. All features discussed for the Gulf present engineering hazards similar to their genetically related features on the Scotian Shelf. 


\section{HUDSON BAY AND APPROACHES}

Several hydrographic surveys have been completed in Hudson Bay and subsequent reports on bottom topography and sedimentation are given by Leslie (1963, 1964, 1965) Leslie and Pelletier (1965), and Pelletier (1969). A compilation of bathymetric features, together with their bathymetric features, together with their naming, was made by Sanford and Grant (1977) for Hudson Bay and Approaches, as well as the entire Atlantic seaboard of eastern Canada. Other bottom studies deal with fauna, and are reported by wagner (see Pelletier $1966 \mathrm{c}$ and Pelletier et al 1968, Wagner 1969).

The floor of Hudson Bay is almost dish-like in shape, except for a central promonitory or arch which extends northerly from the south coast. This feature, called Midbay Bank, divides the bay into two separate basins, both of which comprise a seabed of fine sediments. Winisk Trough separates Midbay Bank and a lesser but still prominent. feature, Henrietta Maria Ridge, to the east. Bathymetric contours generally conform to the configuration of the coast and south-central submarine ridges, but are superimposed by an earlier radial drainage pattern (Fig. 12). Valleys belonging to this system extend offshore from present rivers, or from high elevations on the submarine promontories, and are partly infilled with sediments. Thus they may provide an excellent site for laying pipes or cables providing the fill is not entirely, or mostly drift.

One major northerly trending trench occurs in the eastern central portion of Hudson Bay in Winisk Trough, and an easterly one, Digges Basin, is found in the north at the entrance to Hudson Strait. These trenches are steep, comprise walls of bedrock and presumably are of fault origin. The central trench is $200 \mathrm{~m}$ deep, but the floor is dissected about 30 to $40 \mathrm{~m}$ additionally and shows a broad U-shaped profile indicative of modification by glaciers (Fig. 13). The steepness and depth of these trenches would greatly hinder seafloor crossings of any type.

Ice-rafting is predominant in the inshore areas, and the resulting bouldery deposits overlie a shallow bedrock seafloor sparsely covered with coarse sediments. This surficial feature, particularly on the western shelf of the bay where tides (about $3 \mathrm{~m}$ ) are highest, presents a formidable obstacle to the laying of bottom installations, pipes and cables. However, dredging could clear the seafloor so that a firm foundation would be available for footings.

Except for the work by Grant (1969) very Iittle seismic reflection profiling on the surficial geology of Hydson Bay has been published. Unconsolidated sediments are at least $30 \mathrm{~m}$ thick in the deep parts of the bay, but thin rapidiy on the shelf. The thicker beds comprise mud but the thinner shelf beds are composed of sand and gravel. Thus a variety of engineering problems associated with ploughing and footings are possible. One piston core contained glacial deposits overlain by marine muds in deep water, so a potential drilling problem may be present.

Locally ice-scouring of the sea floor takes place but 1 ts extent is unknown. Surveys by Dionne (1974) show that much of this takes place inshore,

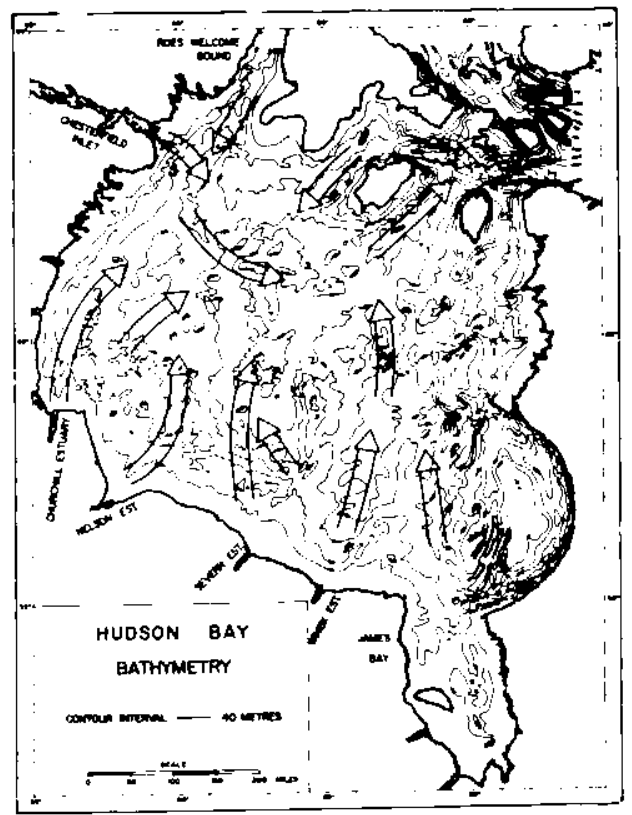

FIG. 12 Bathymetric mop of Hudson Bay. Arrows indicate former radial drainoge pattern, now submerged and partly infilled with sediments. (See Pelletier, 1969).

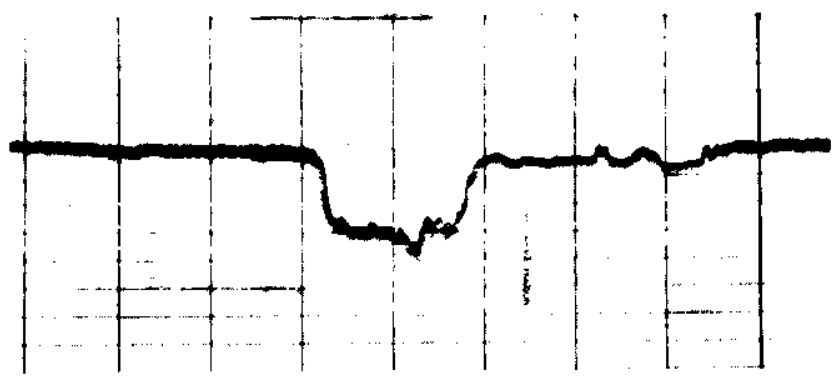

FIG. 13 Bathymetric profile of deep submerged valley occurring west of Ottawa Island. Depth of water is $200 \mathrm{~m}$ over adjacent sea floor; the trench itself is another $130 \mathrm{~m}$ in depth. Note occurance of a minor valley dissected in the lorger one. Two periods of erosion are indicated.

and commonly on the shore itself. Though apparently not as severe as in most lar-northern areas of Canada, drifting ice floes pose a certain problem for engineering works in the inshore area. The offshore appears to be relatively secure from these hazards.

In Hudson Strait, Foxe Basin, and Ungava Bay considerably less work has been carried out than in Hudson Bay. In Foxe Basin and adjacent Hudson strait, botton sampling was carried out by Forgeron (1959) and later by Perry (1961) who described the distribution and nature of the surficial sediments. Because of the ice cover, very little of the basin has been mapped. Hydrographic surveys have been expanded from the area of the major shipping lanes because of interest in exploring for hydrocarbons. A seismic reflection survey was made for Ungava Bay and adjacent Hudson Strait (Grant and Manchester 1970), but this was unrelated to surficial studies and it appears that structural and bedrock features are the main engineering hazards. 


\section{LABRADOR SHELF AND SLOPE}

Off the coast of Labrador, the entire shelf and slope is undergoing systematic geological mapping, supported heavily by the surveying of the Canadian Hydrographic Service. Mapping on Hamilton Bank (Van der Linden, Fillon, and Monahan 1976) is complete, and the surveys over Saglek Bank on the northern Labrador Shelf are presently underway (R. Fillon, personal communication). A comprehensive bathymetric map of the eastern seaboard has been compiled by Sanford and Grant (1977) and recognized topographic names have been introduced. Hamilton Bank was surveyed by personnel aboard CSS HUDSON and CSS DAWSON, with additional soundings provided by Eastcan Exploration, Calgary. Three major, surficial geological units were mapped by Van der Linden et al (1976):

(1) the Cartwright sand and gravel,

(2) the Groswater unit (mainly silt), and

(3) the Goose clay.

Observations have been reported on post-glacial sediment dynamics and paleo-oceanography (Fillon 1976, Fillon et al 1978), this work includes an account of the re-working of glacial till, and a description of the modern sediment distribution. Comments on deglaciation of the Labrador Shelf are given by Fillon (1975) from the aspects; physiography and sedimentology. Vilks and Mudie (1978) reported on the same de-glaciation period, from the micro-faunal and pollen record deduced from piston cores. Many of these cores contained methane gas under some pressure (Vilks and Rashid 1978). Fillon et al (1977) report extensive glacial debris in the Saglek Bank areas we well as to the south (Fig. 14). The occurrence of moraine confirms the earlier work of Grant (1972) who depicted the
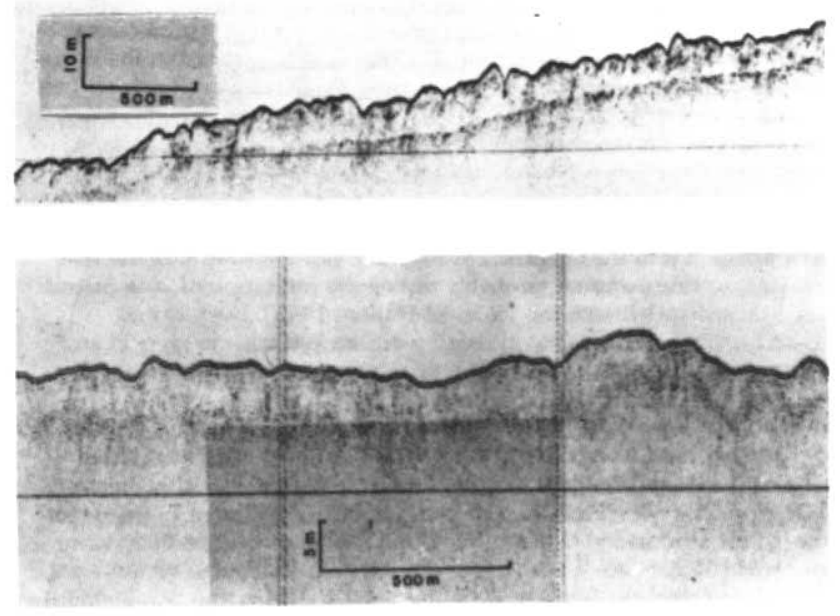

FIG. 14 Pleistocene moraine undergoing current scouring on Labrador Shelf. (Profiles and interpretations by courtesy of R.H. Fillon, Geological Survey of Canada, B.I.O., Dartmouth, Nova Scotia).

thickness of glacial drift on his bathymetric map of the Labrador Shelf and adjacent areas to the north and south. These results were obtained from an air gun, seismic reflection survey and show as much as $300 \mathrm{~m}$ of drift located in the northern and southern portions of the slelf as well as an area in the central shelf. This material has already given severe problens to drillers in the area.

Occurrences of submarine terraces on the Labrador Shelf (Fig. 15) have been reported by Fillon (1978). Some of these terraces represent
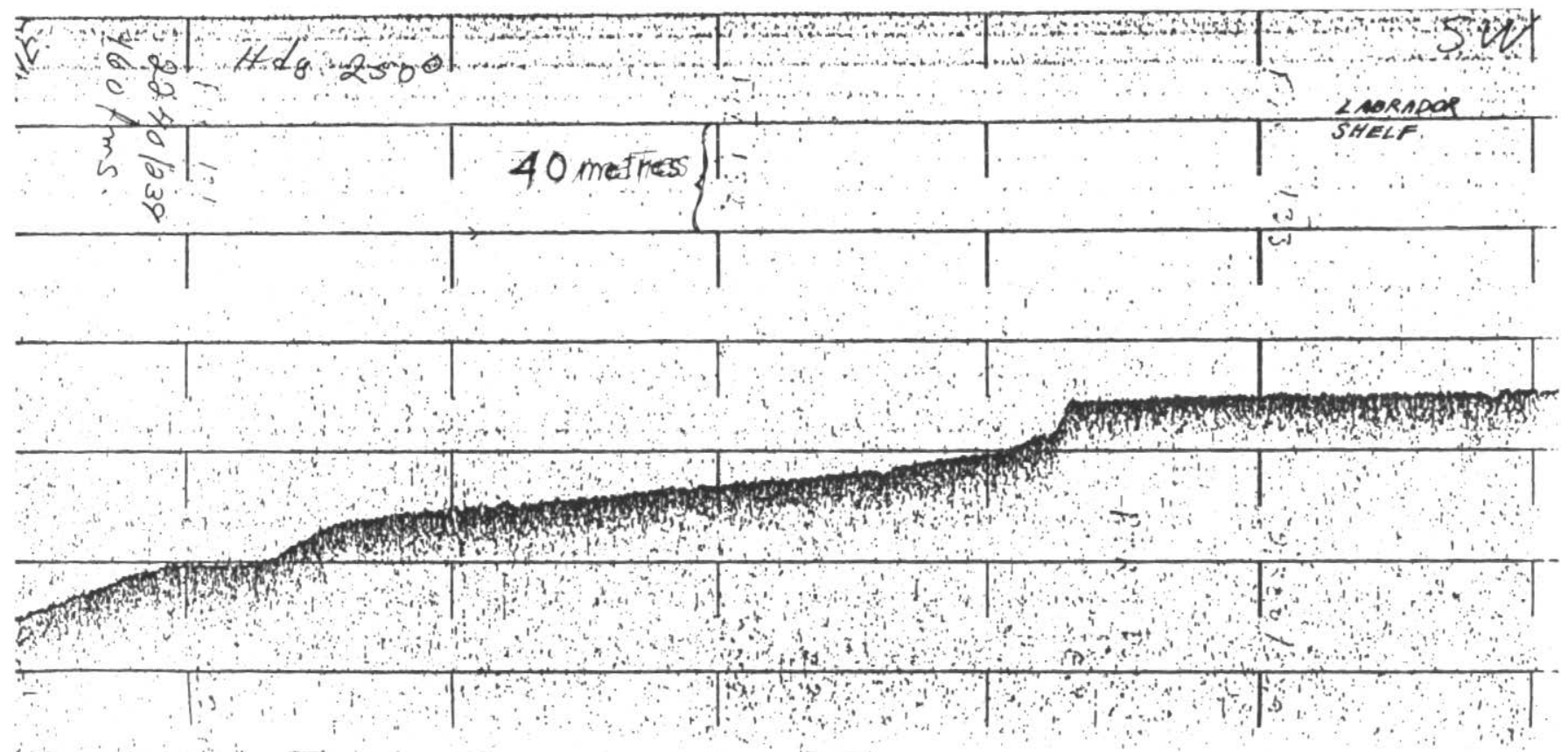

FIG. 15 Echograms showing terraces on the Labrador Shelf. (Courtesy R.H. Fillon and R.H.K. Falconer, Geological Survey of Canada). 
old shorelines, or eroded moraines, and have associated steep scarps up to several metres high thus drastically breaking the regularity of the sea floor. The abrupt change in slope would cause imuediate problems to the laying of pipes and cables in that part of the shelf.

Further offshore at the foot of the continental slope, R. Falconer (personal conmunication) has obtained seisnic reflection profiles of the seabed that show steep scarps about $150 \mathrm{~m}$ in height. The scarps face the continental slope which suggests that huge blocks of surfictal material have dislocated from an upper segment of the slope or outer shelf, and slid basinward to depths of $2000 \mathrm{~m}$. This phenomenon is a grave hazard and must be considered in advance of drilling operations in these great water depths. However, no dates on the period of this activity are known so that these features may be ancient and stable. Slumping or sliding of this nature may be associated with tectonic activity, in which case, bottom recording seismometers (see Barret et $\alpha l$ (1977) should be deployed for long-term monitoring.

Flemish Cap, a submarine knoll, is located about $500 \mathrm{~km}$ east of St. John's, Newfoundland in $126 \mathrm{~m}$ of water at itg shallowest point (Monahan and Macnab 1975). It extends to $1000 \mathrm{~m}$ and was first drilled by Pelletier (1971a) who described the granitic nature of the sumit, its antiquity (592 Ma), and its continental origin. Grant (1971b) carried out seismic reflection surveys in the area and was able to infer much of the geology of Flemish Cap. Monahan and Macnab (1975) reported on the morphology of this feature, notable for its hard surface and steep flanks. It is unlikely that engineering works other than those requiring good footings could be undertaken on the Flemish Cap summit. This area is crossed by icebergs drifting south from Baffin Bay, and thus is subject to iceberg scour and current action.

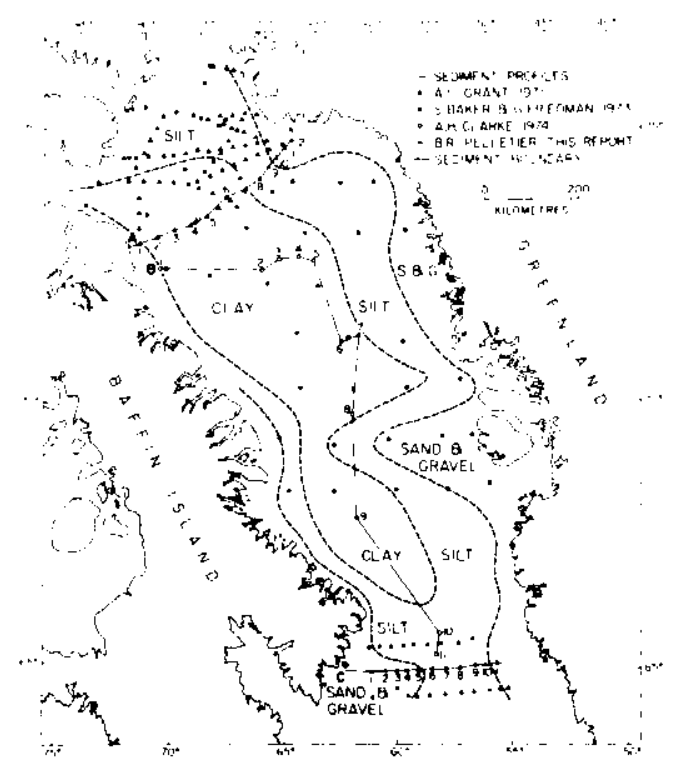

FIG. 16 Sediment distribution of Baffin Bay showing shelf areas of abundant coarse gravel and sand.

(Pelletier, et al, 1975).

\section{BAFFIN BAY AND DAVIS STRAIT}

Hydrographic surveys carried out from icebreakers, as well as various scientific, naval, and conmercial vessels have provided data for the production of bathymetric charts for this region. Although appearing as a large embayment of the Northwest Atlantic, Baffin Bay is actually a small inland sea. It extends $1300 \mathrm{~km}$ (north-south) and is $450 \mathrm{~km}$ wide.

The continental shelf around Baffin Bay is $200 \mathrm{~m}$ deep and varies $20-25 \mathrm{~km}$ in width on the western side, thus producing a very narrow feature. On the eastern shelf an inner portion is $100 \mathrm{~km}$ wide with greatest depth at $300 \mathrm{~m}$. An outer portion extends another $200 \mathrm{~km}$, at most, to a depth of $600 \mathrm{~m}$ but generally shallows to the south where it is $300 \mathrm{~m}$ deep. The shelf is dissected by numerous fjords, some of which extend to the upper part of the continental slope and may incise it as well. From all shelf edges, the slope falls to about $2300 \mathrm{~m}$ in the central basin, the latter of which is a flat, featureless surface.

Although considerable spot sampling and seismic reflection profiling has been carried out locally around Davis Strait and southwestern Baffin Bay to aid shallow bedrock drilling (MacLean et al 1977, MacLean and Falconer 1977, and MacLean 1978), no sedimentary or surficial geology maps have been produced for this area. To the north, somewhat more comprehensive sampling by means of grabs, dredges and corer has been carried out. From sampling the northern portion of Baffin Bay, Grant (1971a) drew sedimentological cross-sections and maps depicting coarse and mostly ice-rafted material inshore, and progressively finer sediments offshore in progressively deeper water. He drew a sedimentational model in which ice-rafting formed a major process in distributing sediments in an anticlockwise direction around the Bay. This dispersal pattern was deduced for older sediments by Marlowe (1968) who examined several cores from wide areas of the Bay. Baker and Friedman (1973) constructed maps showing sediment distribution in which coarse sediment occurs on the inner shelf, finer sediments lie on the slopes, and the finest silts and clays predominately, are in the deep central basin. Dredge hauls by Clarke (1974) and additional sampling data by Pelletier et al (1975) confirmed this distribution (Fig. 16). Kranck (1966) worked on grab samples and small cores obtained by the Canadian Hydrographic Service in response to a request for information concerning cable lays off Cape Dyer. In this study, coarse, ice-rafted sediments were found of fshore and iner, locally derived sands occurred inshore. Baffin Bay and Davis Strait are fraught with major engineering hazards. Inshore are deposits of coarse sediments that were ice-rafted or torn locally from bedrock. Scouring by marine currents may be intense on the shelf as suggested by the absence of fine sediments. This fact must also be considered with regard to engineering work, because the textural model for sedimentation (Fig. 17) (Pelletier et al (1975) indicates that this is an area of sufficient hydrodynamic vigour to cause scouring. It is also an area impinged upon by keels of drifting icebergs (Lewis et al 1977, Loken and Hodgson 1971). The shelf itself is dissected by numerous fjords which may be $800 \mathrm{~m}$ deep. But 
these features could afford protection to bottom installations from the threat of drifting icebergs that continually scour the bottom, some to a depth of $500 \mathrm{~m}$. However, in cases where scour by current and sediment are taking place, or where slumping of sediments is active these fjords could be hazardous engineering sites. Because an oil slick was sighted and sampled over one of these fjords, namely Scott Inlet (Fig. 18, Loncarevic and Falconer 1977, Lewis et al 1977, Levy 1978), they will be the object of engineering and geological enquiry.

Tectonic and seismic behaviour may be intense as Baffin Bay is the locus of many earthquake epicentres (Fig. 19, Wetmiller and Forsyth 1978). Because of this feature, together with excessive sedimentation on the shelf, slumping and turbidity flows are to be expected. Examination of sediment cores by Marlowe (1968) and Piper (1974) suggest that such sediment movement has taken place in the past. Although the central basin appears to be safe from mechanical disturbance so that ploughing or trenching are feasible operations, the very soft nature of the sediments suggests that an unstable substrate may exist that is unsuitable for foundations.
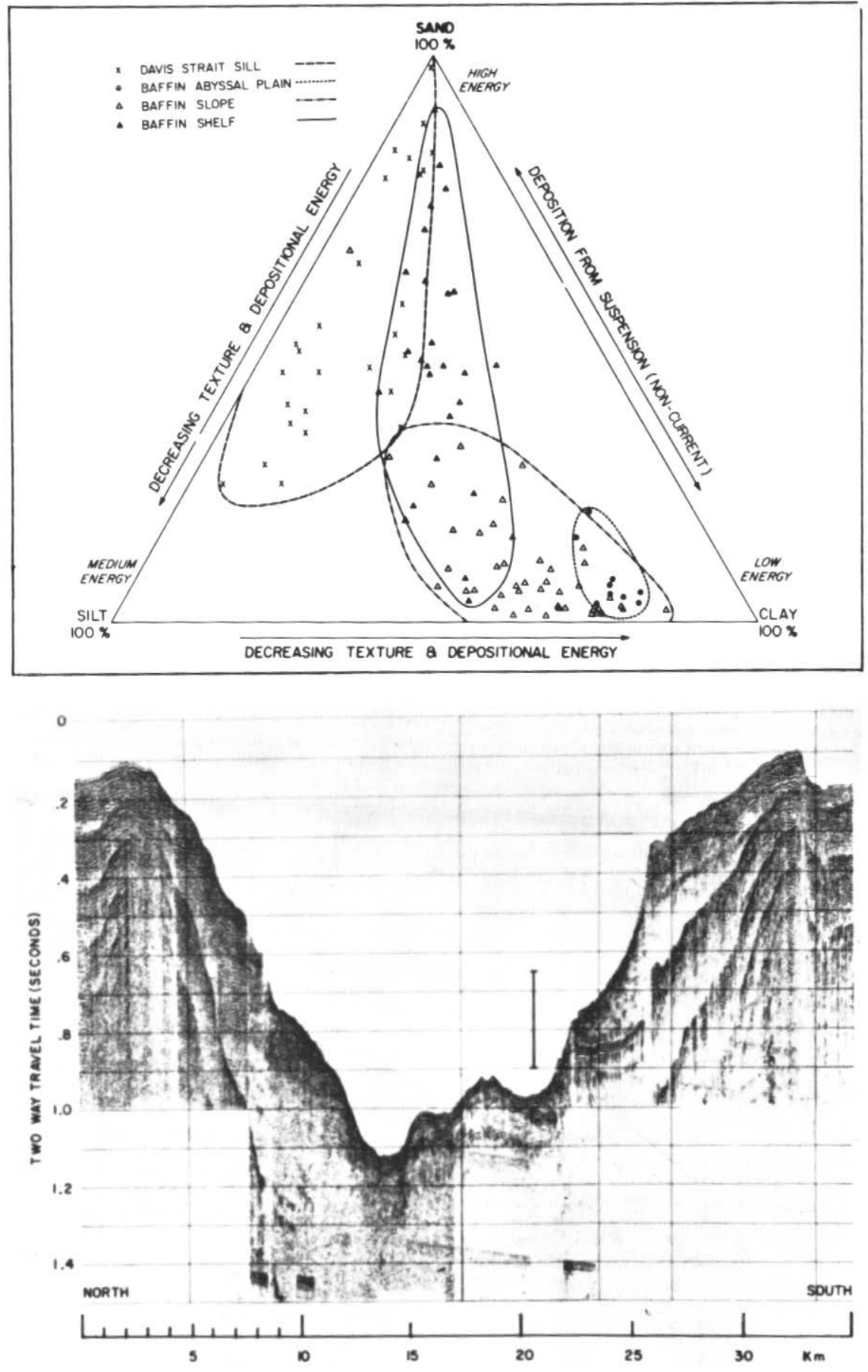

FIG. 17 Temary textural diagram of Baffin Bay sediments. Note position of Davis Strait sediments. This indicates their depositional site is one of greater hydrodynamic vigour than offshore Baffin and Greenland. Also, greater sedimentation is indicated for Baffin Slope and Basin sediments as shown by their position in the lower right-hand portions of the diagram. This is suitable for pipe-laying; Davis Strait would present problems. (Pelletier, et al, 1975).
FIG. 18 Seismic reflection profile across Scott Inlet, Baffin Island.

Canyon has been eroded by rivers and glaciers. (Courtesy of B. MacLean and R.H.K. Falconer, Geological Survey of Canada.) 


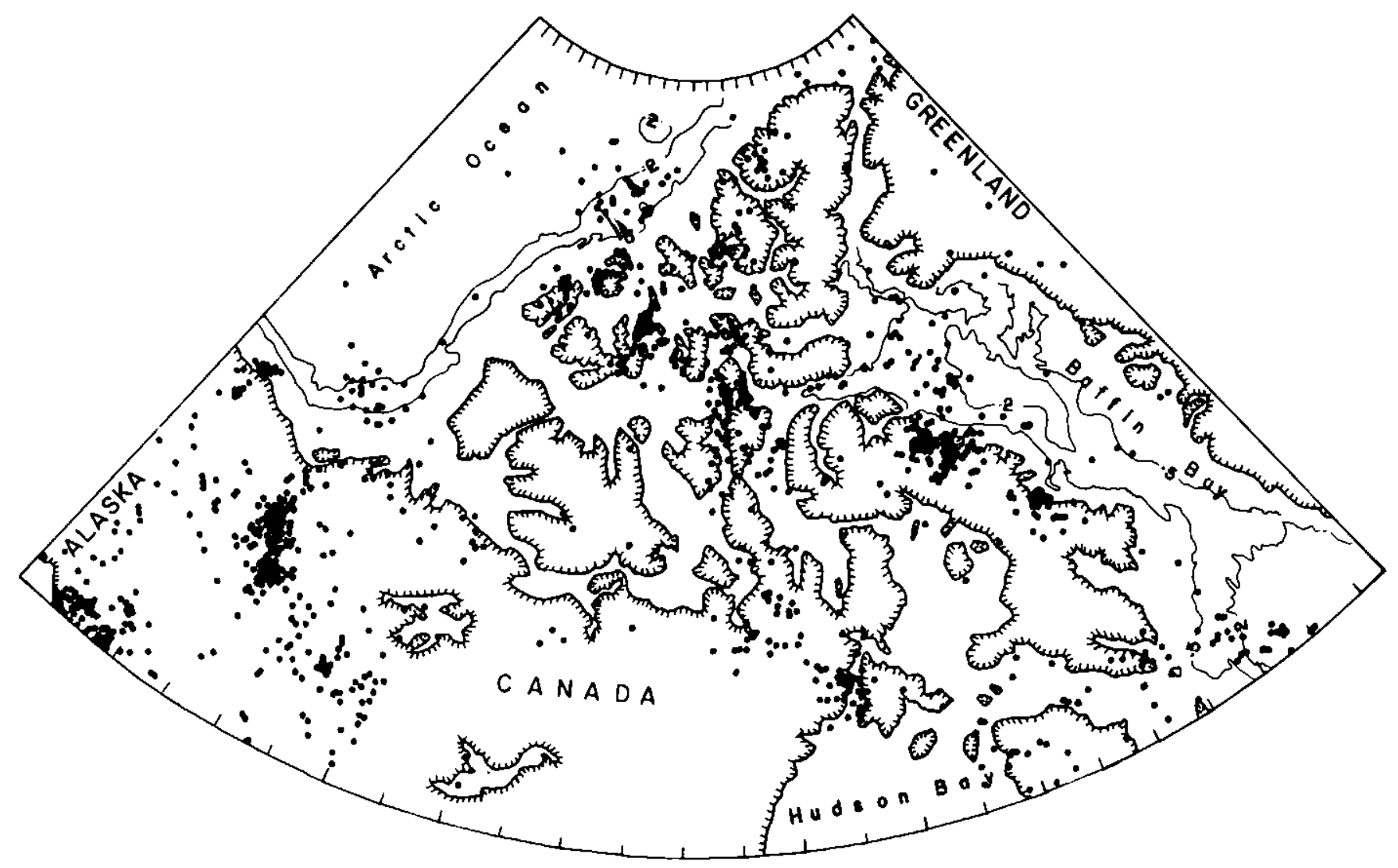

FIG. 19 Distribution of earthquakes greater than magnitude 3 in the Canodian Arctic. Note cluster on Baffin Island and Dhelf. This is a zone of high (3) seismic risk. (Figure modified from Wetmiller and Forsyth, 1978.)

\section{THE ARCTIC ARCHIPELAGO}

In 1956 Fortier and Morley published an account on the geological unity of the Arctic Islands. Here they postulated that the inter-island channels represented a submerged pre-existing drainage system (Tertiary). Pelletier (1960, 1961, 1962a,b, 1966b) later showed that this fluvial system was modified by valley glaciers (Fig. 20), and that these glaciers extended almost $100 \mathrm{~km}$ over the present Arctic shelf. Raised beaches, submerged cirques and hanging tributaries, U-shaped submarine valleys, cores taken at $400 \mathrm{~m}$ depths containing an ancient soil (clay galls, limonitic staining, and plant remains), and a layer with marine fauna overlying the soil were all cited as evidence of terrestrial erosion, glaciation, submergence, and subsequent emergence. However, except for the shipping routes and major portion of Parry Sound, and Amundsen Gulf, most of the area remains hydrographically unsurveyed, so that additional data to support or refute the hypothesis on submarine physiographic development is unavailable. But where surveys have been carried out, the general theory has held. For example, the submarine physiography based on recent hydrographic work carried out in Barrow Strait and Lancaster Sound (see Finlayson, 1976) has been interpreted by Bornhold, Monahan, and Finlayson (1976) as a relict drainage system. It is important to realize that such a drainage system is controlled primarily, if not initially, by geological structure such as faulting and folding (Figs. 21, 22). This physiographic development is associated with plate tectonics and continental drift (Kerr 1979).

Because of this complex topography, and underlying geology, any channel-crossing over the seabed can prove difficult. Steep slopes and scarps - some due to geological structure - can inhibit economical routes. Other routes may be prohibitive altogether, therefore, a judicious selection of "island-hopping" routes together with more favorable axial routes down the submerged and buried valleys may prove to be the best alternative. A stable seabed is apparently present in these submarine troughs and valleys where the gradient is gentle, and undeformed bedding in the near-surface layers suggest an absence of mechanical disturbance.

Bottom sediments have been obtained in many areas of the Arctic channels and bays. Central and eastern Parry Sound are the most thoroughly sampled, but most of this has been carried out in the central and eastern parts. The major contributions on the study of bottom sediments here are by Perry (1961) in Lancaster Sound, Prince Regent Inlet, Gulf of Boothia, Barrow Strait, Peel Sound and Franklin Strait, by Wise (1971) in Barrow Strait, Buckley (1971) in eastern Lancaster Sound, and Bormhold and Lewis (1976) in 

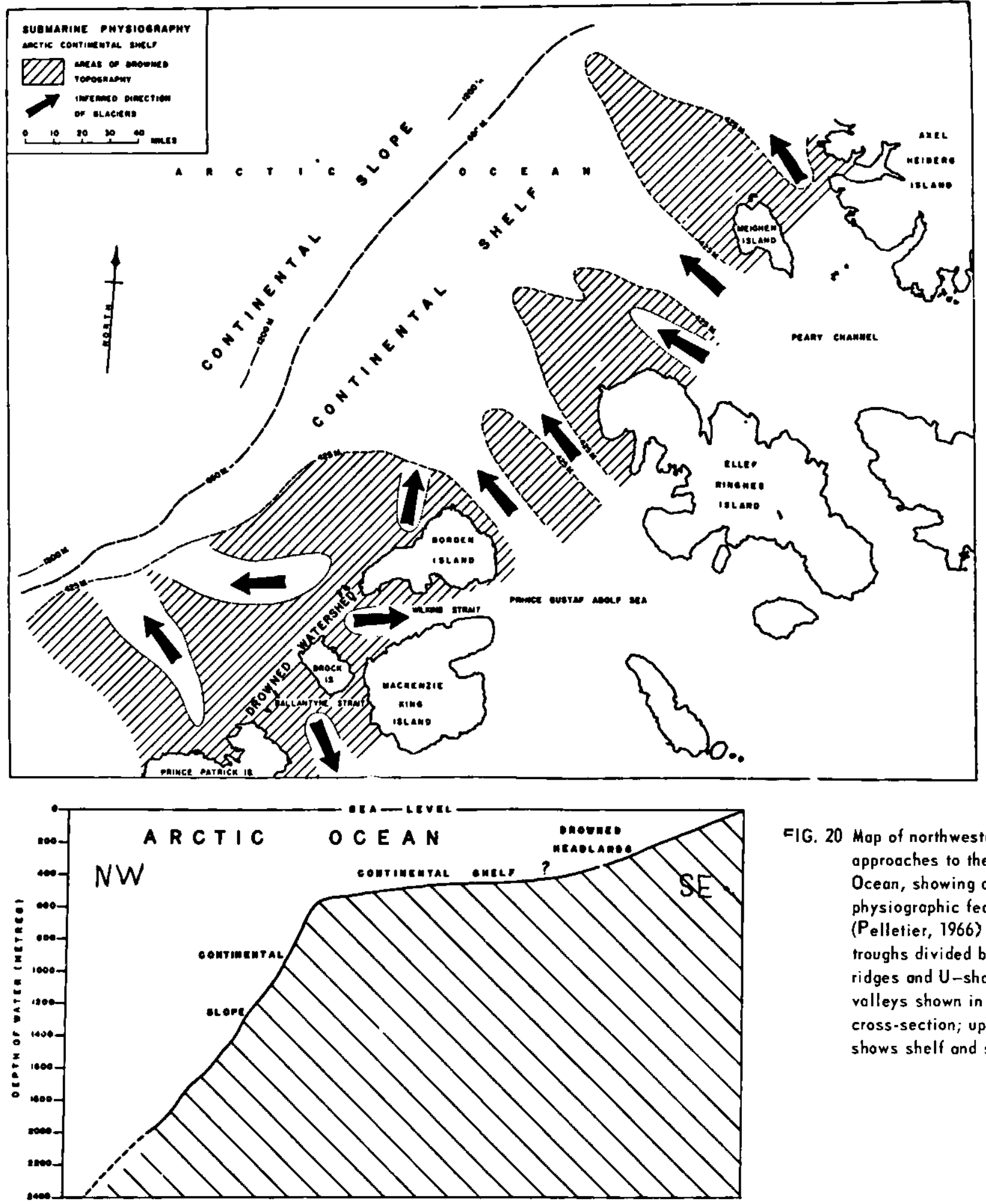

FIG. 20 Mop of northwestern approaches to the Arctic Ocean, showing drowned physiographic features (Pelletier, 1966). Deep troughs divided by medion ridges and $\mathrm{U}$-shaped valleys shown in lower cross-section; upper one shows shelf and slope.

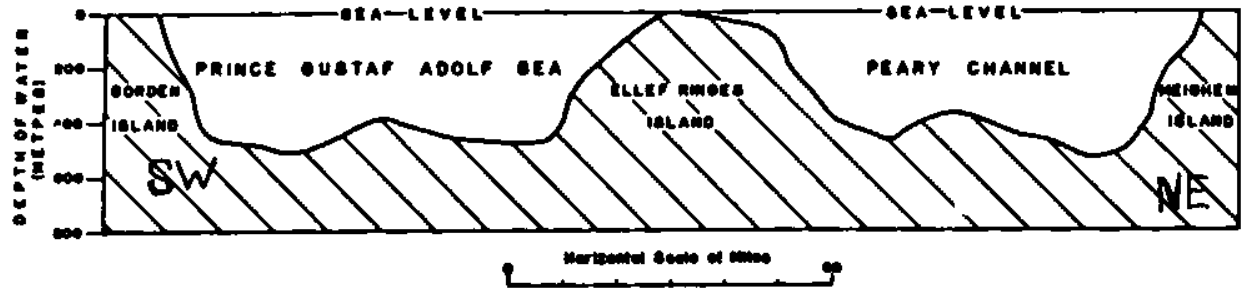




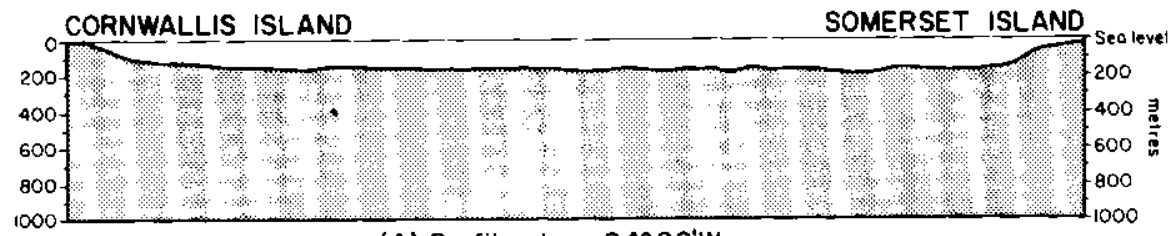

(A) Profile along $94^{\circ} 00^{\prime} \mathrm{W}$

NORTH

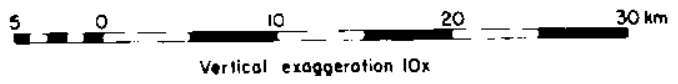

SOUTH

vertical exaggerotion 10

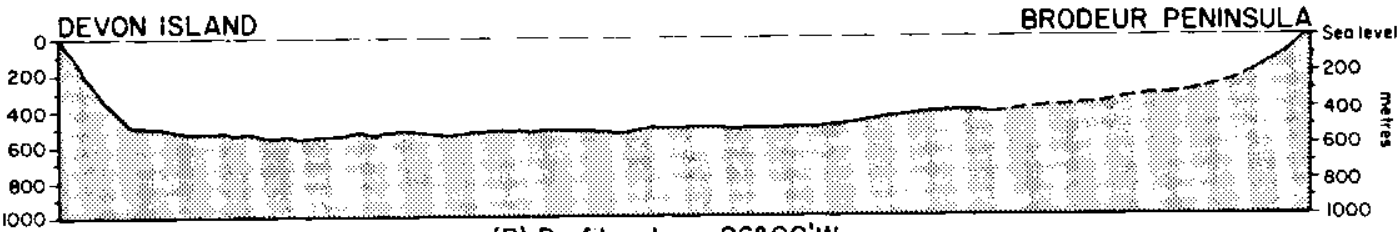

(B) Profile along $86^{\circ} \mathrm{OO} \mathrm{O}^{\prime} \mathrm{W}$

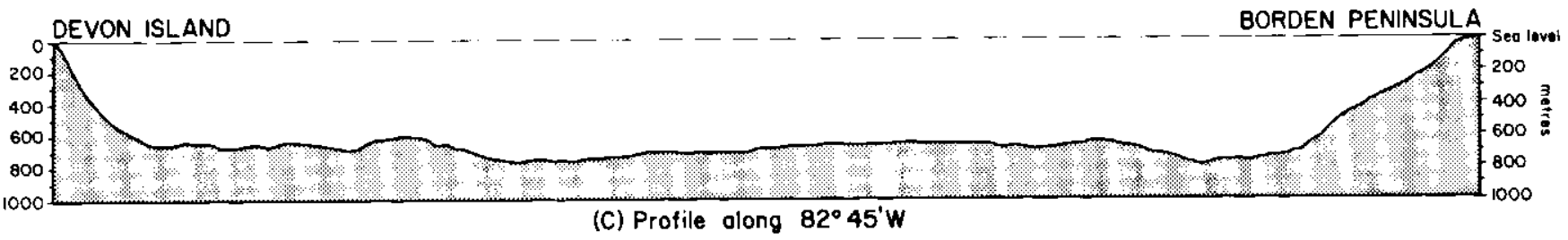

FIG. 21 Bathymetric profiles across Lancaster Sound. All views look east from Barrow Strait (A) to central (B) and eastern (C) Lancaster Sound, to Baffin Bay. (From Canadian Hydrographic Service, Natural Resources Maps 26130,26140, 26145 , and 26240 ).

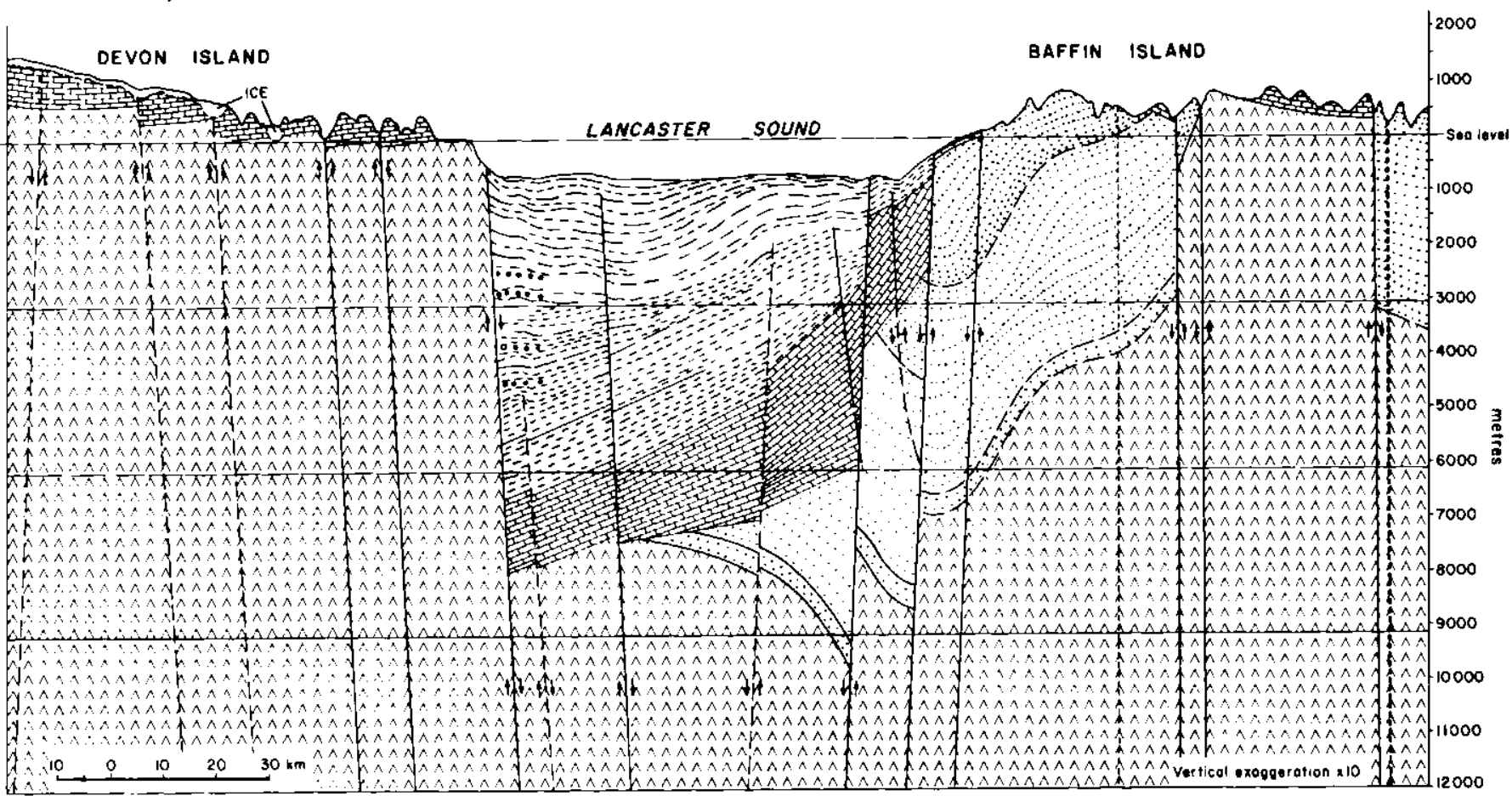

$\therefore$ PRECAMBRIAN SHIELD. Archoan volcanic! and ceyotalline rocks

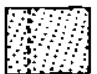

PROTEROIC. SOndstones, sholer, carbonater, volcanics ond dykes

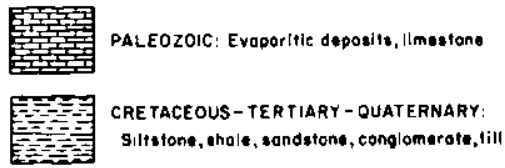

FIG. 22 Geological cross-section of Loncaster Sound between southem Devon Island and northern Brodeur Peninsula, Baffin Island. (From J.W. Kerr, 1979). 


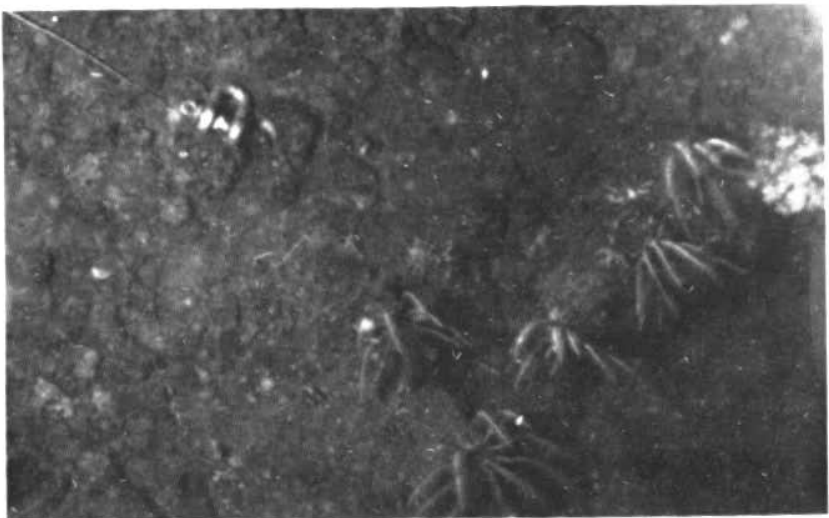

FIG. 23 Crinoid stalks being bent under pressure of bottom currents in western Lancaster Sound and adjacent Barrow Strait in $100-150 \mathrm{~m}$ depth. Note the pebble -cobble pavement and the absence of finer sediments, due to influence of bottom currents.

(Courtesy of C.F.M. Lewis, Geological Survey of Canada).

FIG. 24 Huntec 70 deep tow seismic reflection record in western Lancaster Sound $\left(74^{\circ} 94^{\prime} \mathrm{N}, 89^{\circ} 25^{\prime} \mathrm{W}\right.$ ) showing thick unconsolidated sediments overlying bedrock in deeper water, but thinning to $5 \mathrm{~m}$ in shallower water.

(From C.F.M. Lewis et al, 1977).

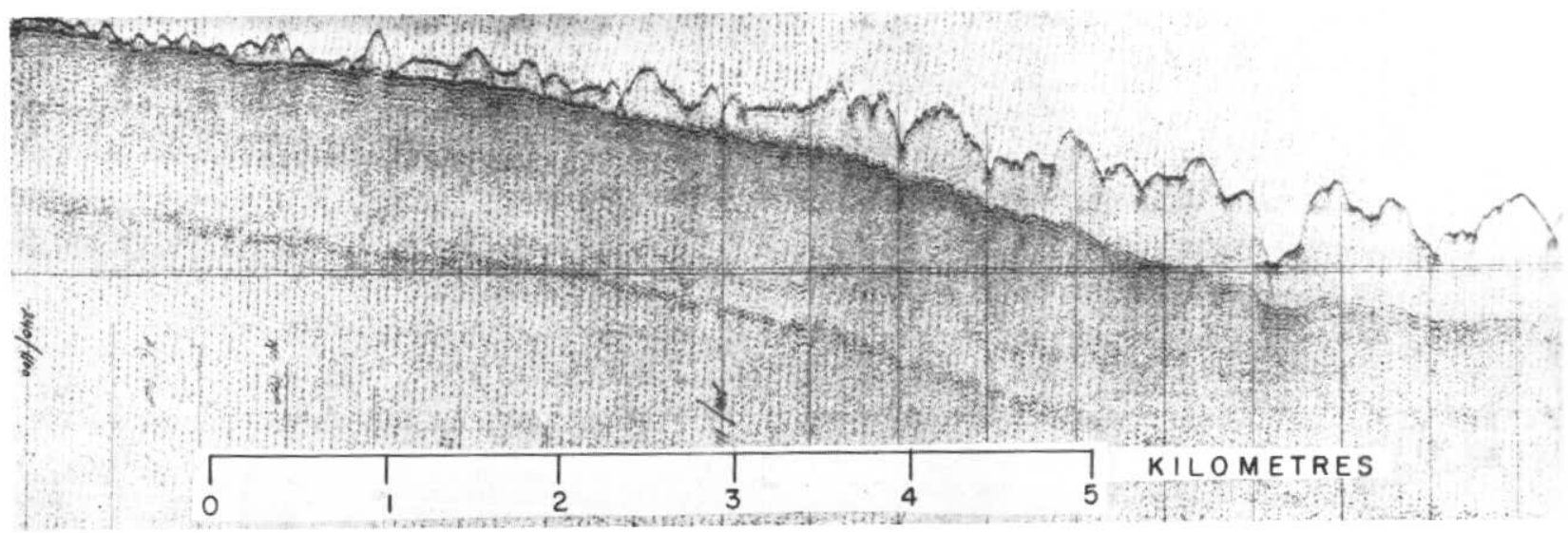

eastern Barrow Strait and western Lancaster Sound. Adjacent areas have also been sampled as follows: the passages from Foxe Basin, Hecla and Fury Strait, and Gulf of Boothia (Forgeron 1959); Cunningham Inlet and southern Barrow Strait (Taylor and Lewis 1975); Peel Sound, Western Barrow Strait, Maxwell Bay, and Croker Bay (Blake and Lewis 1975); eastern Viscount Melville Sound and Strathcona Sound (Bornhold 1976), and selected localities in Radstock Bay, Maxwell Bay, Cuming Inlet, Croker Bay, Strathcona Sound, and Lancaster Sound (Lewis et al 1977).

Seismic reflection profiling was undertaken to establish the nature and extent of the surficial deposits in the area. Generally the central part of Parry Sound and its coastal areas, as well as the inshore portions of the adjacent bays, contain coarse sediments such as sand and gravel while the deeper parts are characterized by finer sediments such as silt and clay. Considerable current scour is taking place in most shallow open areas. In Peel Sound (Blake and Lewis 1975) bottom photographs reveal deposits of clean gravels, as well as plant stems and crinoid stalks tilted in response to pressure from bottom currents (Fig. 23). Evidence of current scour was observed on the records of the seismic reflection profiles (Lewis et al 1977). These observations were made in western Lancaster Sound over a surface of small hummocks lying in $350 \mathrm{~m}$ of water approximately (Fig. 24). Other seismic profiles reported by Bornhold et al (1976) and Bornhold and Lewis (1976) in western Lancaster Sound show evidence of scour in the form of westwardthinning unconsolidated deposits. Such natural activity as erosion and sedimentation presents an engineering hazard that must be considered when planning seafloor crossings or laying installations. Footings and anchorages are the most serious of these considerations. The obvious surficial engineering hazard in this area, and indeed throughout the inshore portion of the Arctic Islands is the occurrence of icescouring of the sea floor (Fig. 25). Studies by P. McLaren (see Lewis et al 1977) have conclusively confirmed this erosive process by personal observations in scuba-diving operations; he also obtained photographs of ice keels gouging the seabed.

A varying topography near shore also poses a hazard to pipe-laying. Cliffs, terraces and fault scarps are present throughout the Archipelago. Some of these features were observed in Jones Sound, Melville Sound, and Lancaster Sound from the submersible PISCES I (Pelletier 1968). The solution to circumvent these problems will probably be illuminated by the development of good marine geological maps. This primary achievement will permit geologists and engineers to plan with confidence. They may follow the grain of the country and "go along with nature" so to speak. As an additional benefit, this easier route will also offer the most protection from ice and current scour in many instances.

Frozen gas hydrates have been indicated in eastern Lancaster Sound at some depth in the geological column (see Milne and Smiley 1978). This is a drilling hazard certainly, but discussion of this feature and its identification must await geophysical confirmation, if not the evidence of the drill itself.

To the northwest along the western approaches to the Arctic Ocean, no seismic reflection profiling has been undertaken on surficial sediments. However, the seabed has been sampled by means of grab and corer in many marine bodies since the inception of the Polar Continental Shelf Project in 1958. 


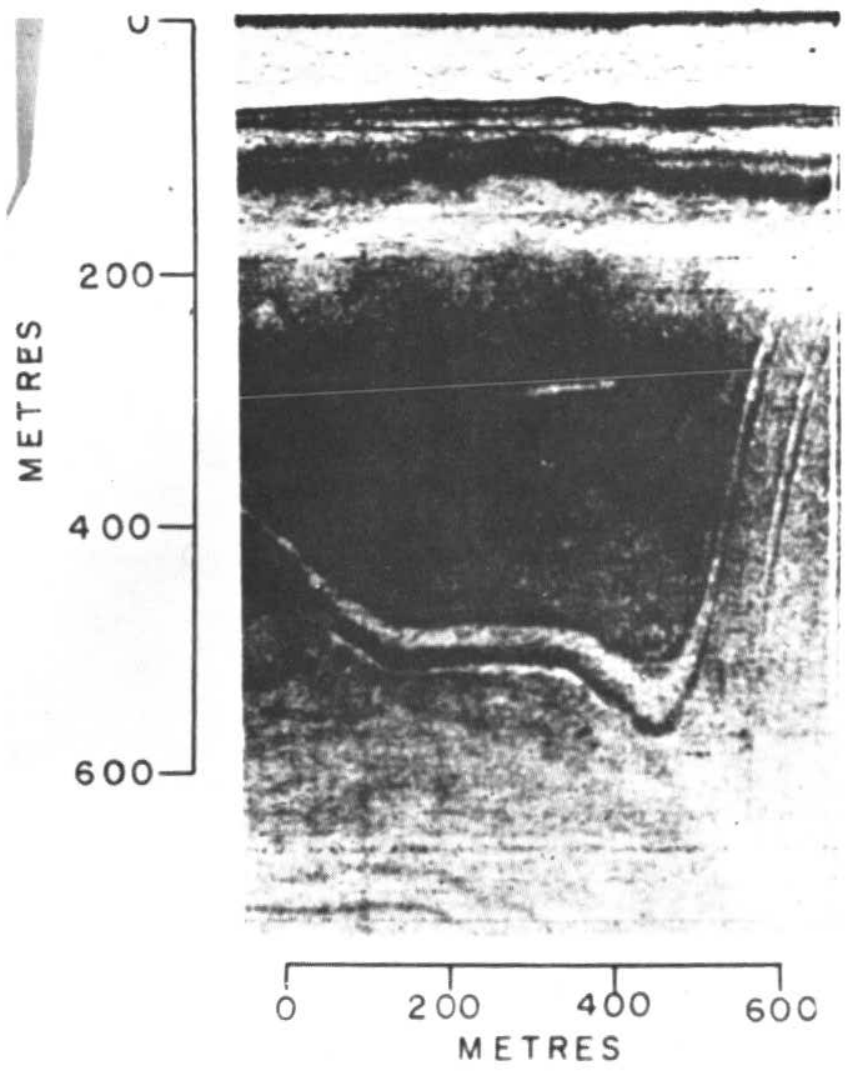

FIG. 25 Bottom scouring by icebergs in Lancaster Sound, Arctic Archipelago. (See McLaren in Lewis et al, 1977) McLaren 1975,1979

Prince Gustaf Adolf Sea (Marlowe and Vilks 1963, Vilks 1964, Marlowe 1964, 1965, 1966a); Peary Channel, Hassel Sound and Sverdrup Channel (Horn 1963, 1966) have all been sampled for bottom sediments. Generally these sediments are fine except near deltas and the central parts of the channels. Current measurements are scarce in these areas so the phenomenon of bottom scour and sedimentation can not be assessed.

The Arctic shelf and slope has also been sampled for sediments in an area lying between Axel Heiberg Island and Prince Patrick Island although only the northern portion was reported (Pelletier $1960,1961,1962,1966 \mathrm{a}, \mathrm{b}, 1967)$. Sand occurs on the drowned headlands which extend northwesterly from the islands. The intervening areas between the headlands extend from the inter-island channels, and most contain silt and clay. These sediments lie on a seabed that was earlier a river bed modified by glaciers.

Offshore in the Arctic Ocean the hazards to engineering activities are obvious. For example, drifting ice scours the bottom for many' months of the year; an equally persistent ice cover introduces difficult if not impossible operations. There is so little geological work completed in this exceptionally hostile area that it has the distinction of becoming Canada's last frontier.
Inside the Archipelago, new yearly ice in protected bays actually offers an advantage to seafloor crossings in that once the installations are emplaced in the soft easily ploughed muds, the winter landfast ice protects the installations from the action of drifting ice. This principle should hold throughout the Archipelago. However, it is also suggested that unless thin layers of this fine sediment are present, foundation problems due to an unstable bottom could arise.

\section{THE BEAUFORT SEA}

In this section of the paper, a case history of problems dealing with surficial geology and engineering hazards is given in some detail. Work on surficial geology, and the routine hydrographic surveys were given considerable impetus from the Canadian petroleum industry and the federal government in 1969 and 1970. With the discovery of oil in Prudhoe Bay, Alaska and at Atkinson Point, District of Mackenzie, exploration and survey were accelerated. The cruise of HUDSON 70 from the Bedford Institute of Oceanography carried out a multi-discipline survey including oceanography, marine biology, hydrography, geology and geophysics. CSS BAFFIN, CSS PARIZEAU and CSS RICHARDSON also formed part of the fleet of federal research vessels greatly adding to the bathymetric, geological and geophysical coverage. In subsequent years, charter vessels such as MV THETA, MV PANDORA and the government vessel MV NAHIDIK and the submersible PISCES IV as well as numerous commercial vessels carried out offshore surveys. The Director of the Polar Continental Shelf Project was instrumental in aiding their work. Notwithstanding the exceptional amount of work accomplished in geophysics and regional geology, only the sedimentological and morphological features of the Beaufort shelf are discussed here.

The Beaufort Shelf slopes gently to the $100-\mathrm{m}$ isobath approximately $100 \mathrm{~km}$ northwest of Tuktoyaktuk Peninsula, and about $70 \mathrm{~km}$ off the coast near the Yukon-Alaska border. Mackenzie Canyon dissects the shelf from the mouth of Mackenzie Bay at the northwest edge of the delta, to the $500-\mathrm{m}$ isobath lying near the shelf edge. Smaller but abundant morphological features are present and include the following: offshore bars in the coastal zone, ice scours to water depths of $50 \mathrm{~m}$, pingos in the eastern part of the shelf between the 30 and $80-\mathrm{m}$ isobaths approximately, diapirs and mud lumps or possibly mud volcanoes beyond the $80-\mathrm{m}$ isobath in the eastern part of the shelf and at depths of 45 to $50 \mathrm{~m}$ in the vicinity of the east wall of Mackenzie Canyon, a possible thermokarst lying between 80 and $100 \mathrm{~m}$, and considerable slumping, faulting, and dislocation of surficial beds on the upper continental slope extending to depths of $800 \mathrm{~m}$ at least.

From a total of approximately 1000 bottom samples, 256 representative samples were texturally analyzed and the type of sediment was designated for each sample. Sediment distribution maps were drawn (Pelletier 1975, see Vilks et al 1979) which showed coarser sediments in the western part of the Beaufort Shelf as well as in the extreme east; the former were interpreted as ice-rafted and are considerably overconsolidated due possibly to excessive ice-loading northwest of Herschel Island. In the east, coarser sediments may be a lag resulting from the scouring 


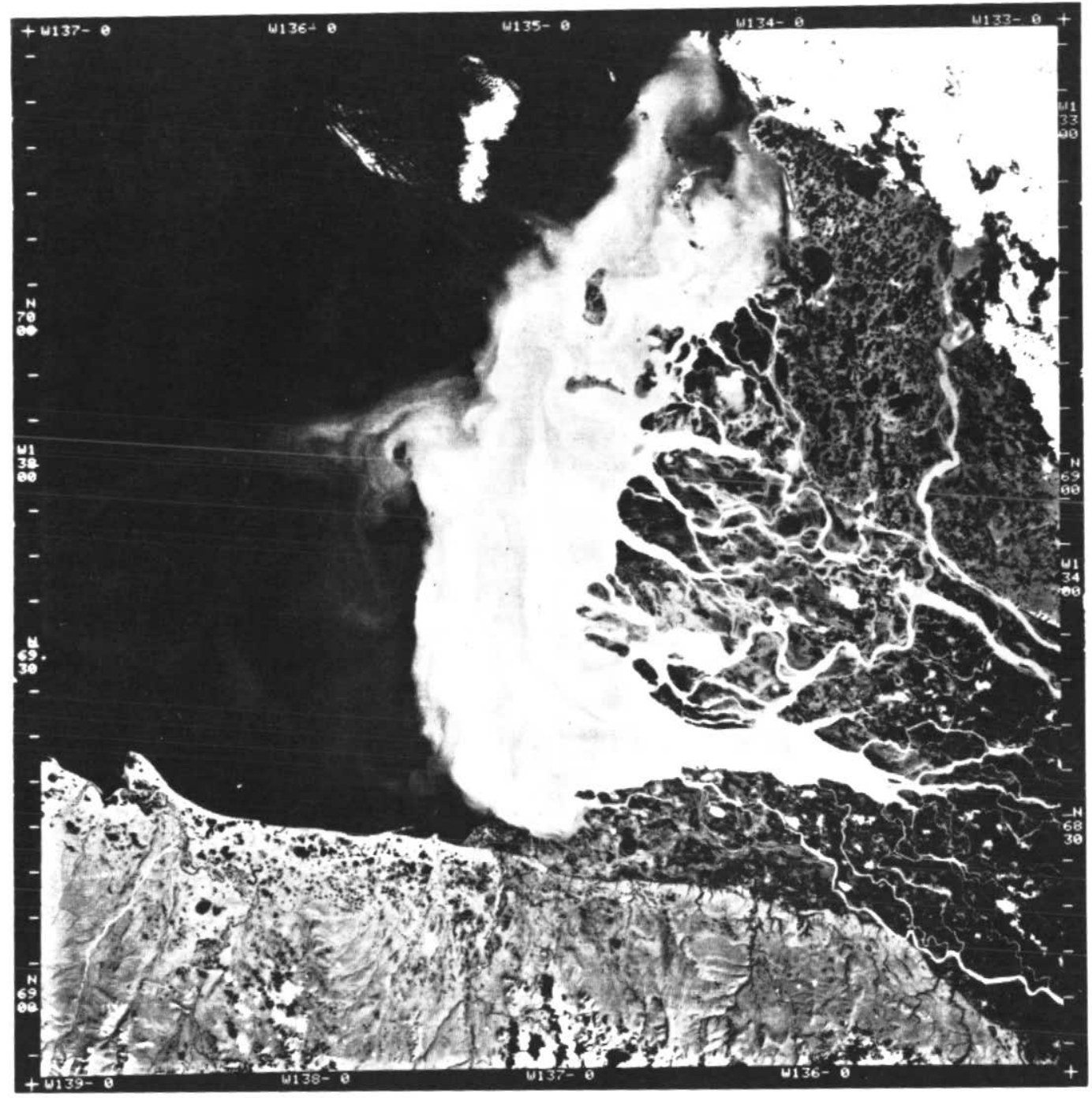

FIG. 26 Landsat 1 photo of sediment plume, MacKenzie Delta. (Courtesy of Energy, Mines and Resources Canada).

action of bottom currents. Sands predominate nearshore, along the coastal islands and spits and generally on the eastern portion of the shelf. Silts are most common in Mackenzie Bay and in the seaward area forming the periphery of the sand deposits. Clays are found mostly in Mackenzie Canyon and on the continental shelf lying immediately adjacent to the eastern wall of the canyon.

Generally sediments discharge from Mackenzie River and some disperse northerly about 30 to $40 \mathrm{~km}$ over Mackenzie Canyon while the bulk of the load moves easterly along the coast. This eastward movement is due to the influence of the Coriolus force and can be demonstrated from the movement of the sediment plume as soon in satellite photographs (Fig. 26), and from the spits which are directed easterly off headlands and islands in the coastal area. Some sediment appears to move westerly at the outer shelf edge but this may be due to the influence of the Pactfic gyre, particularly in the winter, which moves in a clockwise direction in the southern Arctic Ocean.
Evidence of upwelling at the shelf edge was detected by Vilks (1972) in a study on Arctic foraminifera, and by Bornhold (1975) from an examination of oceanographic properties such as salinity and temperature, and the suspended sediments collected from that area.

By equating sediment texture and depositional velocities given by Hjulstrom (1935) some indication was given of the maximum hydrodynamic vigour present over the depositional sites (Pelletier 1975). Using the following equation in which SI units are employed, energy volume was calculated in terms of ergs $/ \mathrm{cm}^{3}$.

i.e. Energy/volume $=\frac{1}{2}$ density (velocity) ${ }^{2}$ Thus, sediment texture, depositional velocities and energy are related.

From these calculations, energy environments were assigned to each sampling site, and a hydrodynarnic environmental model was drawn (Fig. 27). The results showed three major environments: (1) a very low energy regime represented by the depositional site of the clay; (2) a low energy regime shown by the silt deposits; and (3) an intermediate energy 
regime near shore where the sands were deposited. A fourth (high) energy regime was not shown as sampling inshore from the larger ships was not possible. The ternary textural modeI used for Bay of Fundy (Pelletier 1974) and Baffin Bay (Pelletier et al 1975) also confirmed the selection of these environmental regimes, but generally the Beaufort Sea is one of low energy. This is due to the ice cover present over the shelf during much of the year.

Fifty piston cores were obtained at geographically representative sites over the continental shelf and slope (see Pelletier in Vilks et al 1979). Generally they indicated an absence of major sand components in the seabed west of Mackenzie Canyon, as well as in the canyon itself; but, X-radiographs of some cores (Fig. 28) indicate sand and silt layers undetected in the fresh uncut cores. On the shelf east of Mackenzie Canyon, sand and silt form the major part of the core. From a study of 13 boreholes of the APOA project \#4 (1971) by Lerand and from the HUDSON 70 cores it appears that deltaic marine sands, including beach types, were deposited at the present continental margin but have receded landward with a rising sea.

From a textural examination of 1100 subsamples extracted from the HUDSON 70 cores, columnar sections were drawn and plotted in their respective geographic locations. These diagrams clearly show the difference in texture between sediments in the east and those in the west, in that the latter are finer-grained (Fig. 29). They also show the distinct location of the deltaic marine sediments in the eastern area of the shelf, and their absence to the west. The effects of a rising sea level are indicated in that the sands and deltaic complex retreat shoreward contemporaneously with the retreating shoreline and transgressing sea. Cores from the slope show evidence of slumping or turbidity currents, indicating an unstable seabed.

Bathymetric coverage over the Beaufort Shelf has been greatly enhanced by the continued efforts of the Canadian Hydrographic Service. Five maps have been interpreted by Monahan (1973) who has clearly outlined several important geomorphologic zones. These include the zones of ice scour (Figs. 30 and 31$)$ as reported by Pelletier and Shearer (1972), Lewis (1978), Shearer and Blasco (1975), and Wahlgren (1979a, b). This zone extends from near shore to the $50-\mathrm{m}$ isobath from which point seaward Lewis, Pelletier and the others think they are relict. Both Lewis and Blasco (personal communication), and Pelletier and Shearer (1972) have obtained profiling records which show grooves filled with sediment. Relief of the associated ridges is also subdued and lacks the sharp profiles of new ridges and hence, are though to be ancient features (Lewis, in preparation).

Hazards due to ice scouring have already been given for other areas. For example, seafloor crossings are difficult unless undertaken below the seabed. In the Beaufort Sea, dredging can be carried out and installations buried in pits or trenches for protection against ice keels dragging the bottom. However, ice lenses and ice-bonded sediments will offer a hindrance but not an insurmountable one. A greater obstacle may be occasioned by an unstable surficial sediment when dealing with footings, anchorages, or foundations.

other features to consider are the shoals, sub-

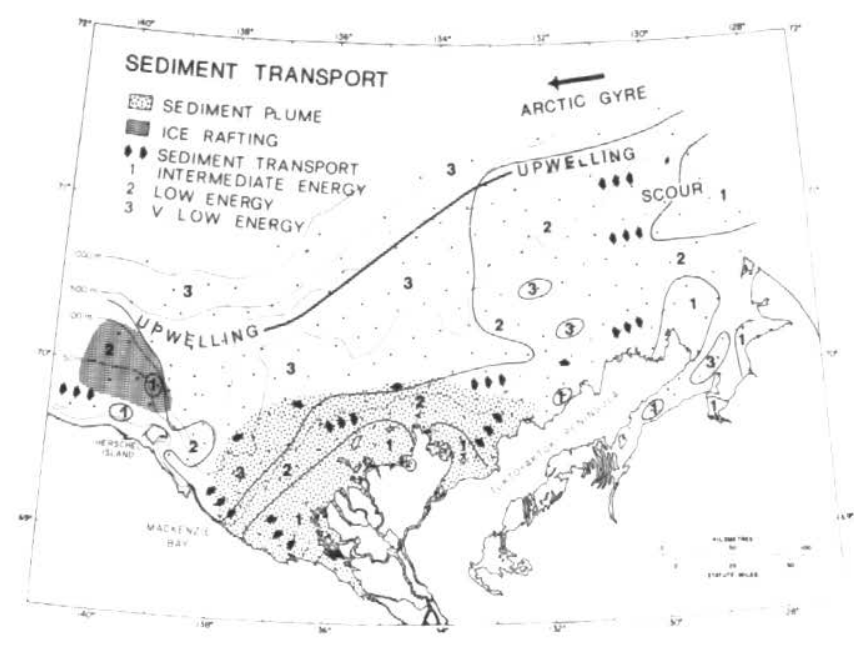

FIG. 27 Model of sediment transport in Beaufort Sea.

(Pelletier, 1975). Sands and gravels occur in Zone 3

(also Zone 4 along coast, but not shown), silts in

Zone 2, and clays predominately in Zone 1.

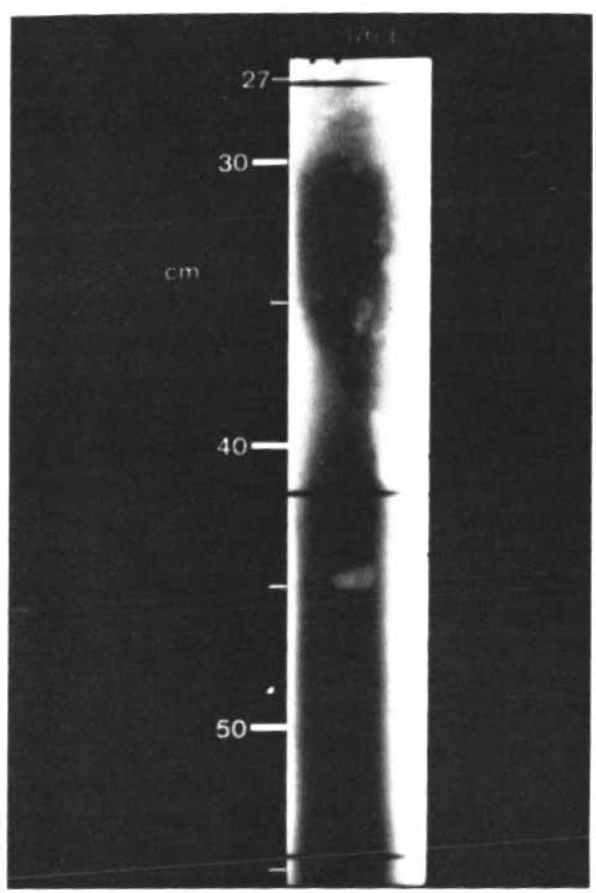

FIG. 28 X-radiograph of sediment core from Beaufort Shelf shows presence of fossils and pebbles; also dark and light bands which indicate fine and coarse sediments respectively. (Courtesy of C.F.M. Lewis and R.V.Wahlgren, Geological Survey of Canada). 

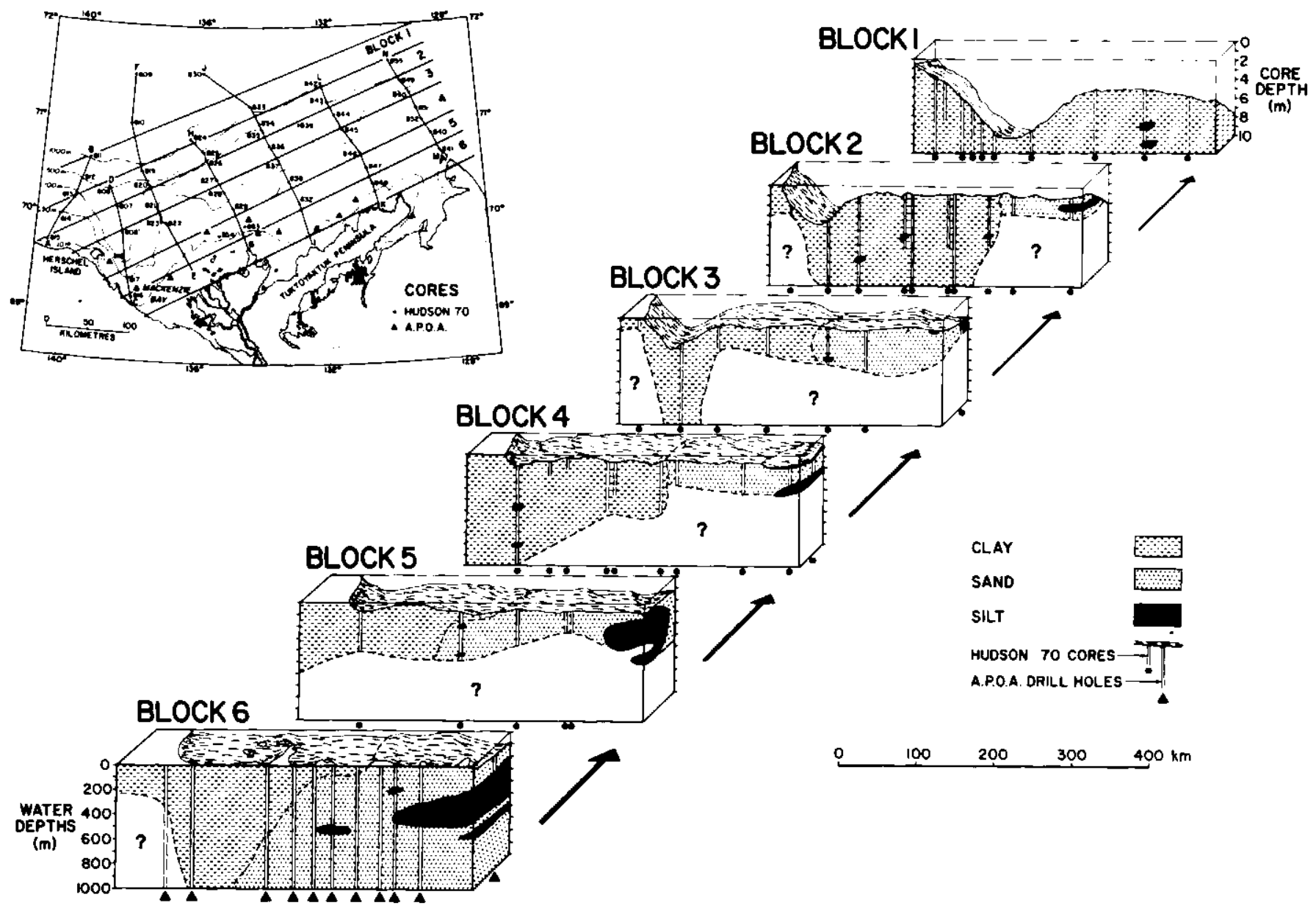

FIG. 29 Perspective blocks of Canadian Beaufort Shelf showing deltaic-marine sediments onshore and their absence in the western portions, i.e. west of Mackenzie Canyon. Inset shows location of blocks and cores. Diagram after author, based an E.S.S. HUDSON piston cores (See Pelletier in Vilks et al., and Lerond, 1974).

marine ridges and sand bars that occur in the coastal zone. Some bars are associated with current action and may occur in the vicinity of sand waves. Both features must be considered in the same context in that the engineer may be dealing with a mobile rather than a permanently stationary body. Another shoal feature to consider is the presence of ridges rising $10 \mathrm{~m}$ above the seafloor in water depths of $20 \mathrm{~m}$ or so (Fig. 32). These ridges have similar longitudinal and cross-sectional profiles as the Stamukhi ridge reported by Reimnitz and Maurer (1978) in the Beaufort Sea off Alaska. However, their ridges are in 10 to $15 \mathrm{~m}$ of water, and presumably are formed at the point where the moving ice of the polar pack collides with the seaward edge of the fast ice that extends from land. Ice keels drag the bottom and push the sediment into mounds and, by continually exerting pressure, force the mounds shoreward. Reimetz and Maurer suggest that winter drilling could probably take place shoreward of these ridges as equipment would be protected from drifting ice in the lee of the ridge. Submerged and buried river beds (Shearer 1971) such as the Kugmallit Channel must be examined with respect to engineering hazards. Because these relict drainage channels are infilled with soft fine sediment, less loading ability will be available than for the sandy beds of the old beaches. However, the relict infilled valleys will possibly offer and advantageous route for buried pipelines, should pipes be required to transport hydrocarbons from, or to the off shore.

Monahan (1973) also depicts numerous mounds, some of which are pingos (ice-cored features) (Fig. 33), and others that are diapirs (or mud volcanoes) (Ftgs. 34-36). At the shelf edge the mounds are so closely spaced that plotting at the scale of the map is impractical. In this zone of so-called hyperbolic reflectors (see Monahan 1973), sonic and seismic profiles obtained on the HUDSON 70 cruise show that many of them are intrusions or diapirs of mud. Further seaward, slumping is evident and numerous dislocations are recorded from the upper slope down to depths of $800 \mathrm{~m}$ (Fig. 37).

As well as positive features, the profiling instruments have detected depressions that are proctically the width of the submarine pingos (Fig. 38). These are found seaward of the $80-\mathrm{m}$ 


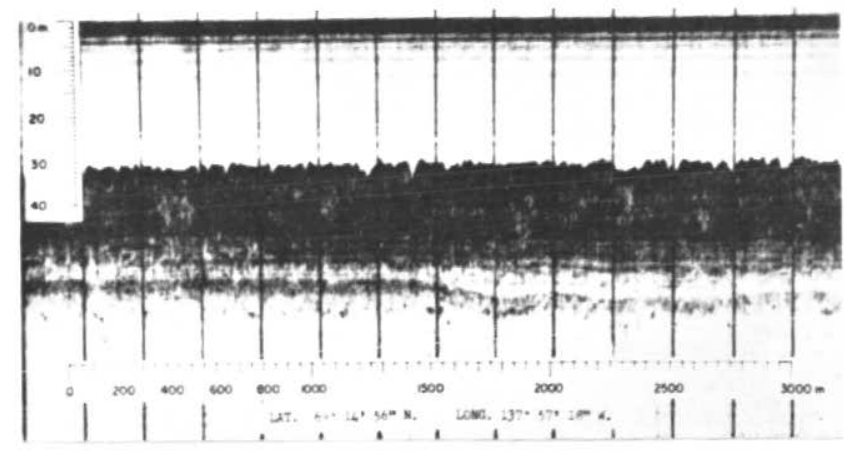

FIG. 30 Profile details of ice-scouring in Beaufort Sea near McKenzie Canyon (Canadian Hydrographic Service).

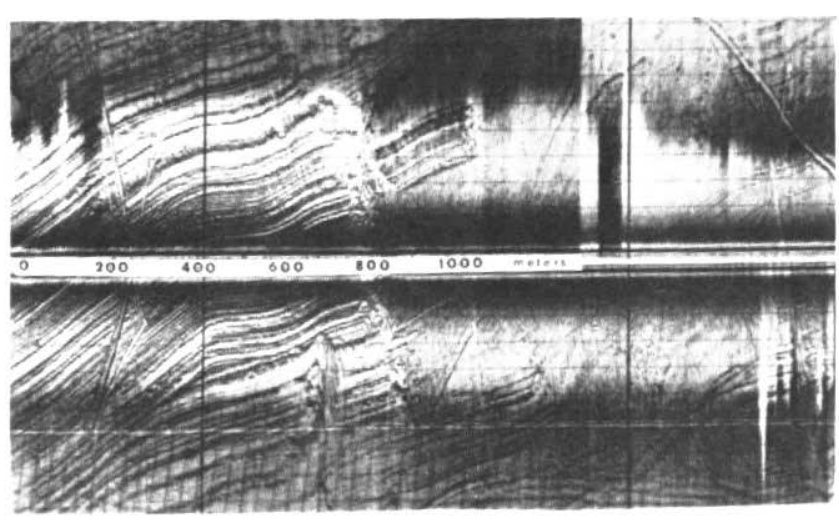

FIG. 31 Side scan sonargraph of ice-scouring in southeastern Beaufort Sea. (Courtesy of C.F.M. Lewis and S.M. Blasco, Geological Survey of Canada).

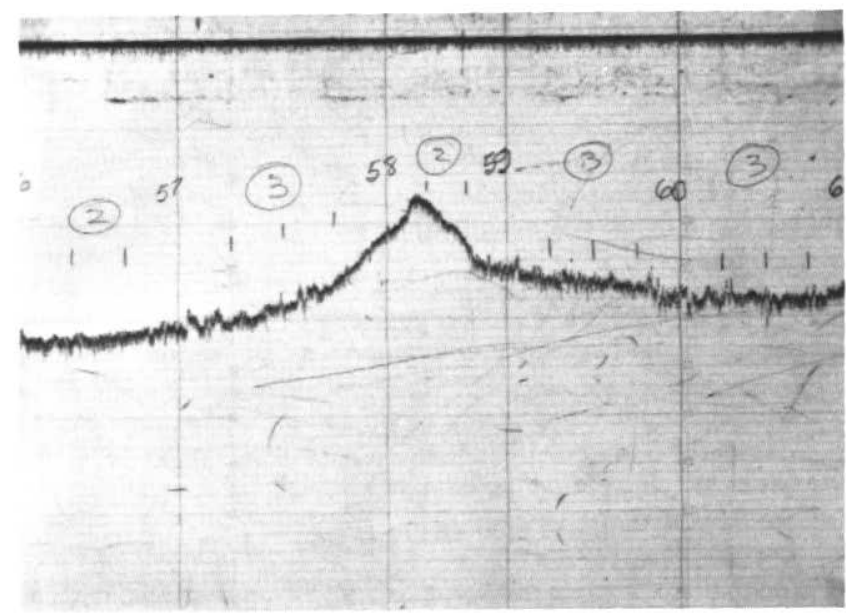

FIG. 32 Offshore submerged bar lying in $30 \mathrm{~m}$ of water with a summ it $10 \mathrm{~m}$ higher. Occurrence north of northeastern portion of Tuktoyaktuk Peninsula. (Canadian Hydrographic Service). isobath approximately, in the vicinity where Hunter and Judge (1975) have suggested the occurrence of the seaward boundary of continuous subsea permafrost (Neave et al 1978, Hunter et al 1976, 1978a, B, Hunter and Blasco 1979). It is possible that degradation of permafrost is taking place at this depth by the action of sea water introduced through mechanically derived fissures in the surficial sediments on the seaward face of the continental slope and outer shelf. Because the ice in the pingo is thought to be fresh water in origin, then it becomes thermodynamically possible to establish a model of melting fresh-water ice and subsequent collapse of the pingo. In essence, a thermokarst is developed. With time, sufficient water is available in the sediment to introduce thixotropic movement under the stress of uneven loading or shock.

This in turn would produce mud lumps, or diapirs, and subsequent slumping and dislocation down the continental slope (Pelletier et al, in preparation). These processes may not all be thermodynamic and mechanical in origin. The presence of gas hydrates may also play a role, particularly as gas has been identified in the seismic profiles (M. O'Connor and S. Blasco, personal communication). The evolution of morphological features on the shelf is partly illustrated in the isometric model of a portion of the Beaufort Shelf (Fig. 39).

Following from previous arguments (Shearer et al 1971) that the submarine pingos are also submarine in origin (because the land pingos are eroded by transgressing seas) it follows that the offshore pingoes are old and post-date sea level rise, probably some 6000 years ago. Dates are scarce, so that much of the history must be construed by argument. From this, it is argued that the line of pingos lying parallel with the coast near shore, and in the shallowest areas of their occurrences, must be the youngest. But a zone of the seafloor approximately $40 \mathrm{~km}$ wide contains no pingos, yet the sediment texture is similar to the beds offshore. This may be due to the discharge of warm Mackenzie River water flowing eastward, thus inhibiting the development of a so-called heat sink for the fresh water-bearing surficial sediments in the coastal zone. It is postulated here that if sea level continues to rise, a new zone of bingos will form shoreward of the present shallow ones, because the water there will be deeper and colder in that zone.

The mechanism for forming offshore binqoe is not clear but certain elements must be acknowledqed: (1) sediment texture and porosity, (2) the hydroloqic cycle, (3) the thermodynamic regime, (4) the oceanographic setting, (5) the ancient sedimentary depositional site, i.e. deltaic marine, and (6) the existence of permafrost to considerable depth beneath the seafloor. It is noteworthy that pingos are found on land in deltaic terrain and therefore it is reasonable to assume that the pingos offshore occur in submerged deltaic terrain, similar to that of the present Tuktoyaktuk Peninsula. Textural and faunal evidence (including barren zones) in the cores supports this view (Vilks, Wagner and Pelletier 1979). Also, the pingos occur in the deltaic deposits, which are unlike those deposits west of Mackenzie Canyon, where submarine pingos are absent altogether.

Pingos offshore may be occupying the sites of former land pingos that have disintegrated and 


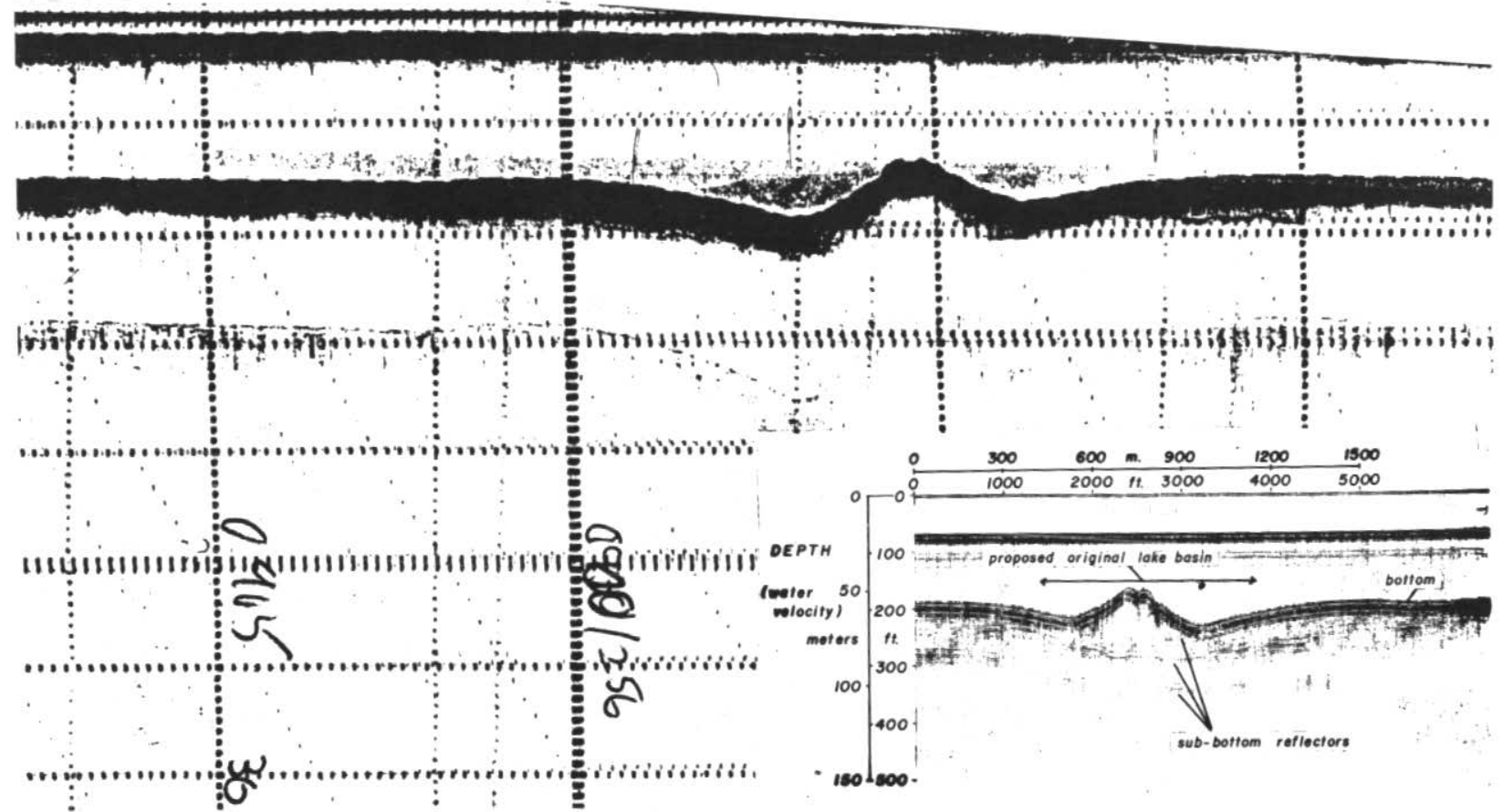

FIG. 33 Submarine pingo, Beaufort Shelf. C.S.S. HUDSON echogram, 1970. Note sub-bottom reflector beneath pingo is not visible.

collapsed due to the effects of a rising transgressive sea. This collapse would be both thermal and mechanical. After the offshore pingos grow and collapse, it is suggested here that mud volcanoes or diapirs then occupy the sites of the former pingos. Gradually these features would disintegrate to form mud flows along the continential slope where the gradient steepens and thus further assist the dislocation of the seabed down the face of the continental slope.

Regardless of the origin of these features, two sets of facts remain: (1) the pingos and mud lumps exist, and (2) slumping and dislocation also exist. This indicates the instability of the seabed in those regions. Gas, water, and frozen gas hydrates in the sediment increase the dangers to seafloor engineering. But other facts must also be considered: (1) the time scale of these events, and (2) the true topographic profile under consideration. This will lead to a truer perspective of the problems without eliminating conscientious appreciation of potential obstacles and dangers.

\section{SUMMARY AND CONCLUSIONS}

Most of the Canadian offshore is unmapped according to the standards of the systematic, geological mapping introduced by L.H. King. Maps of the Bay of Fundy, Scotian Shelf and Grand Banks are based on the best available geological and navigational control. On the Labrador and British Columbia shelves, the mapping standards follow those of King but the geological control is somewhat less. All other seabed areas off Atlantic and Arctic Canada (except the Gulf of St. Lawrence and Beaufort Sea) are sampled unequally, both in terms of bottom material and reflection profiling by
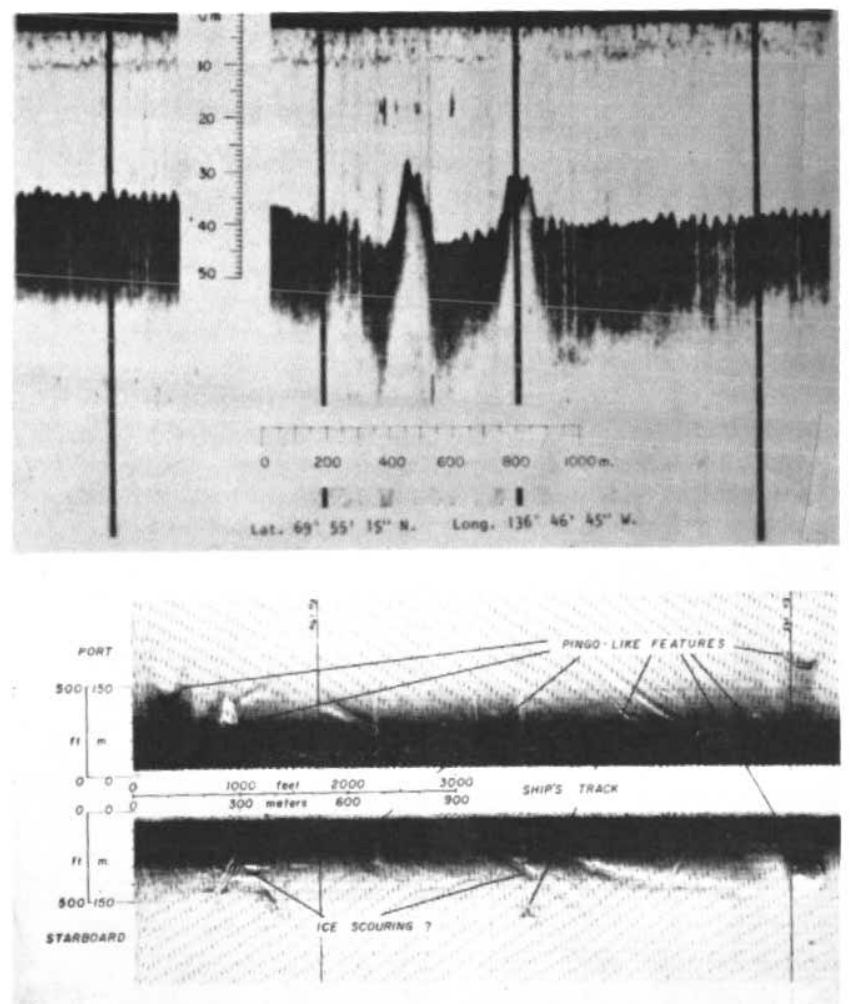

FIG. 34 Diapirs (mud volcanoes), Beaufort Sea, eas $t$ wall of Mackenzie Canyon. (Canadian Hydrographic Service). 


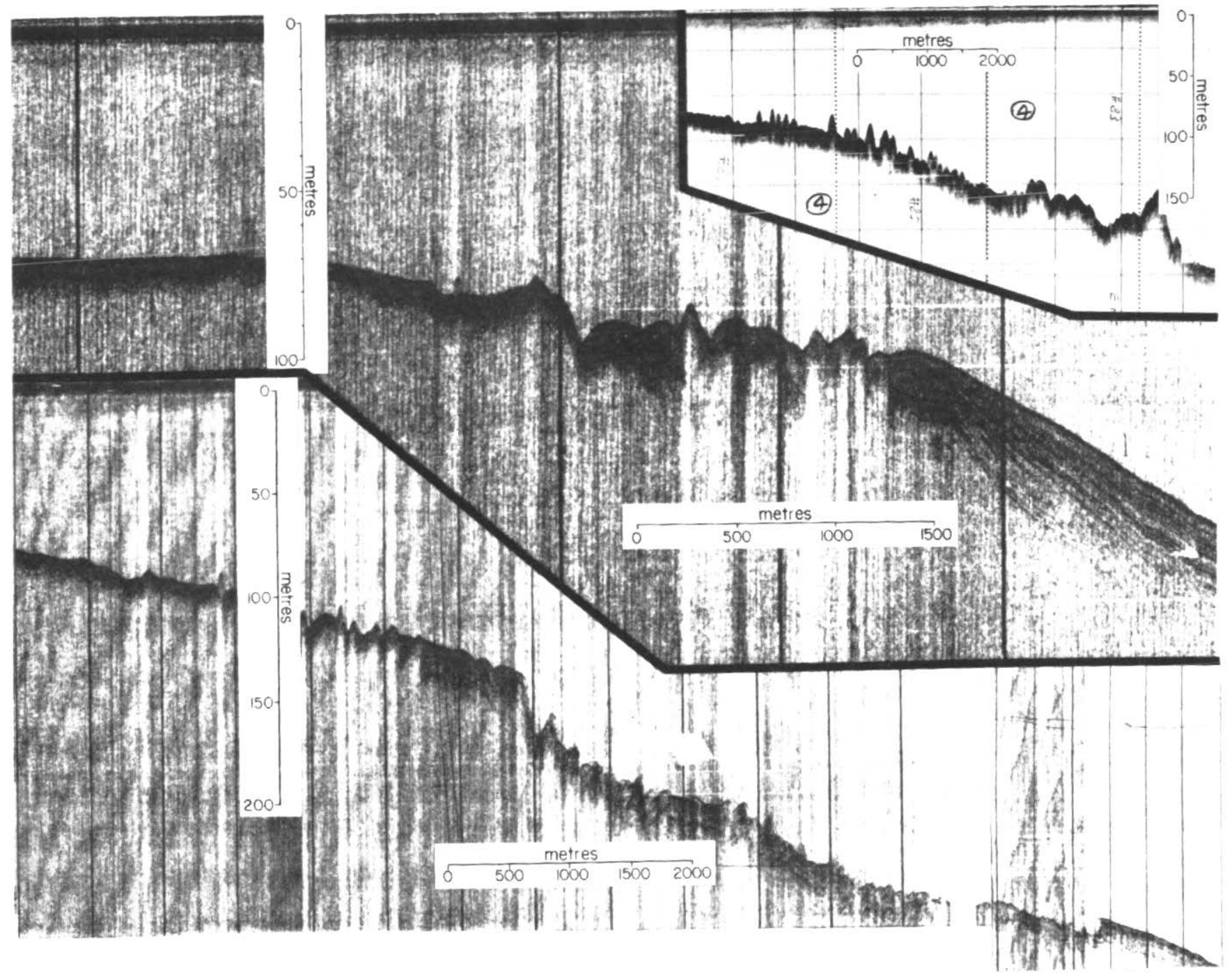

FIG. 35 Diapirs, mud lumps, mud slump-mass movement on Beaufort Shelf and Slope. (Courtesy, S.M. Blasco, Geological Survey of Canada).

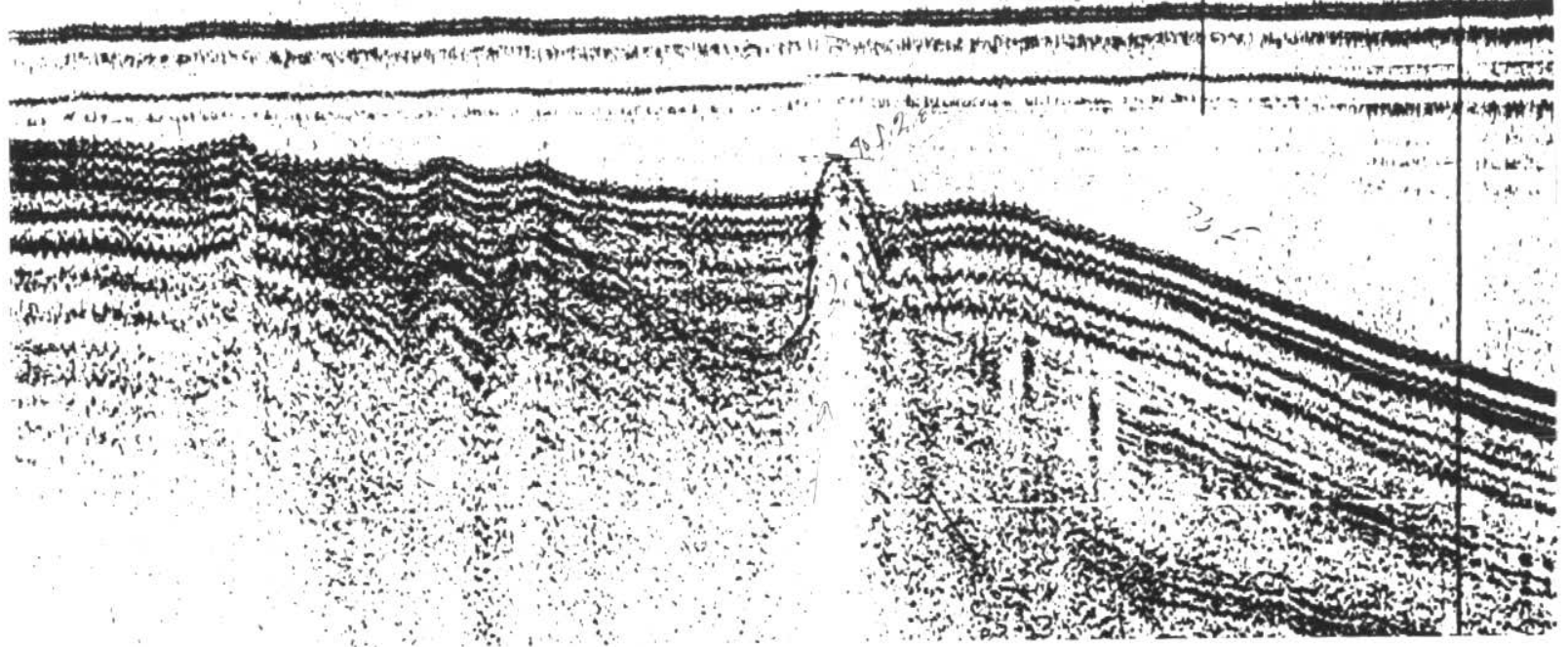

FIG. 36 Mud diapirs at Beaufort Shelf-Slope break. C.S.S. HUDSON seismic reflection profile, 1970. 


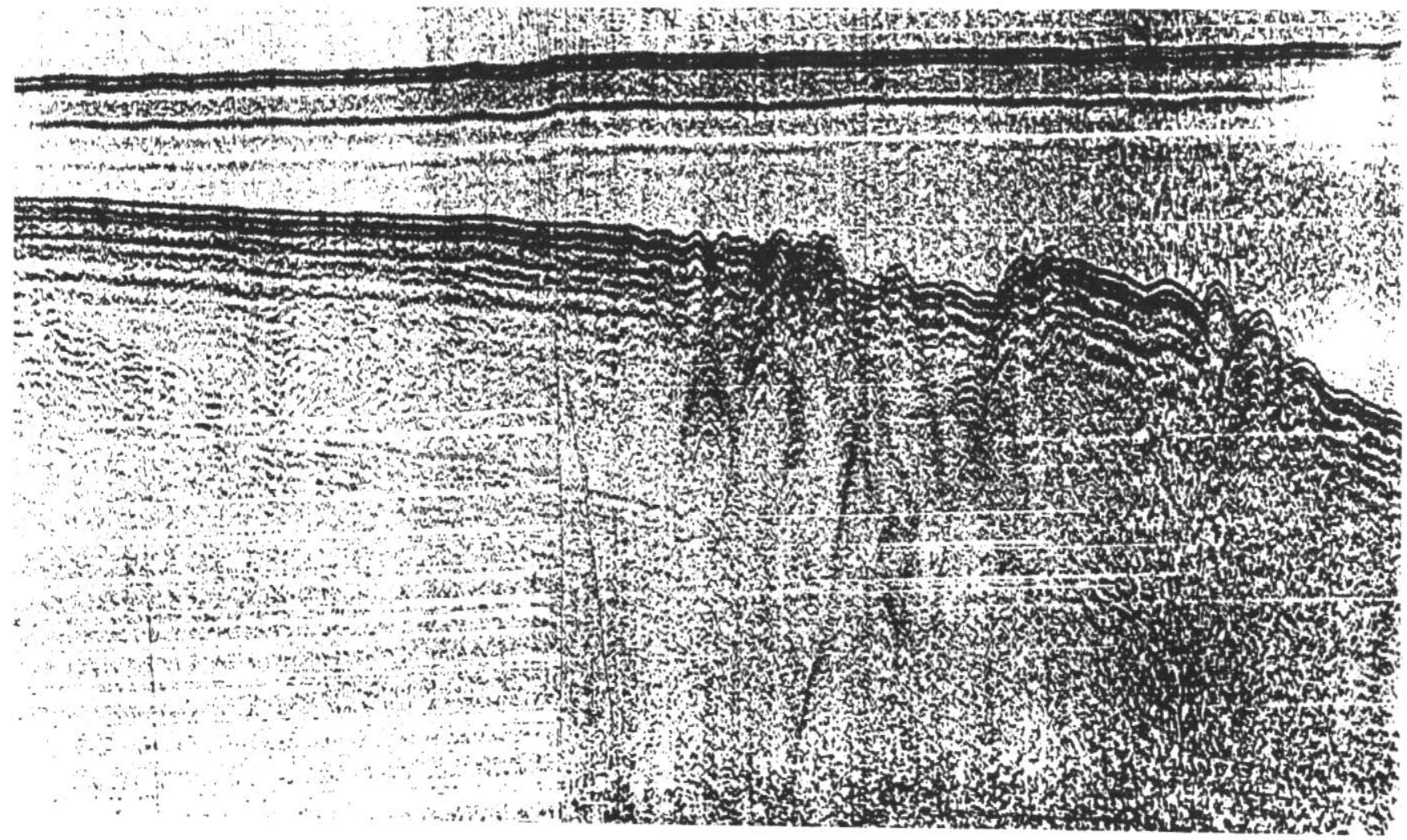

FIG. 37 Dislocation and movement of bottom layers Beaufort Slope, C.S.S. HUDSON seismic reflection profile,1970.

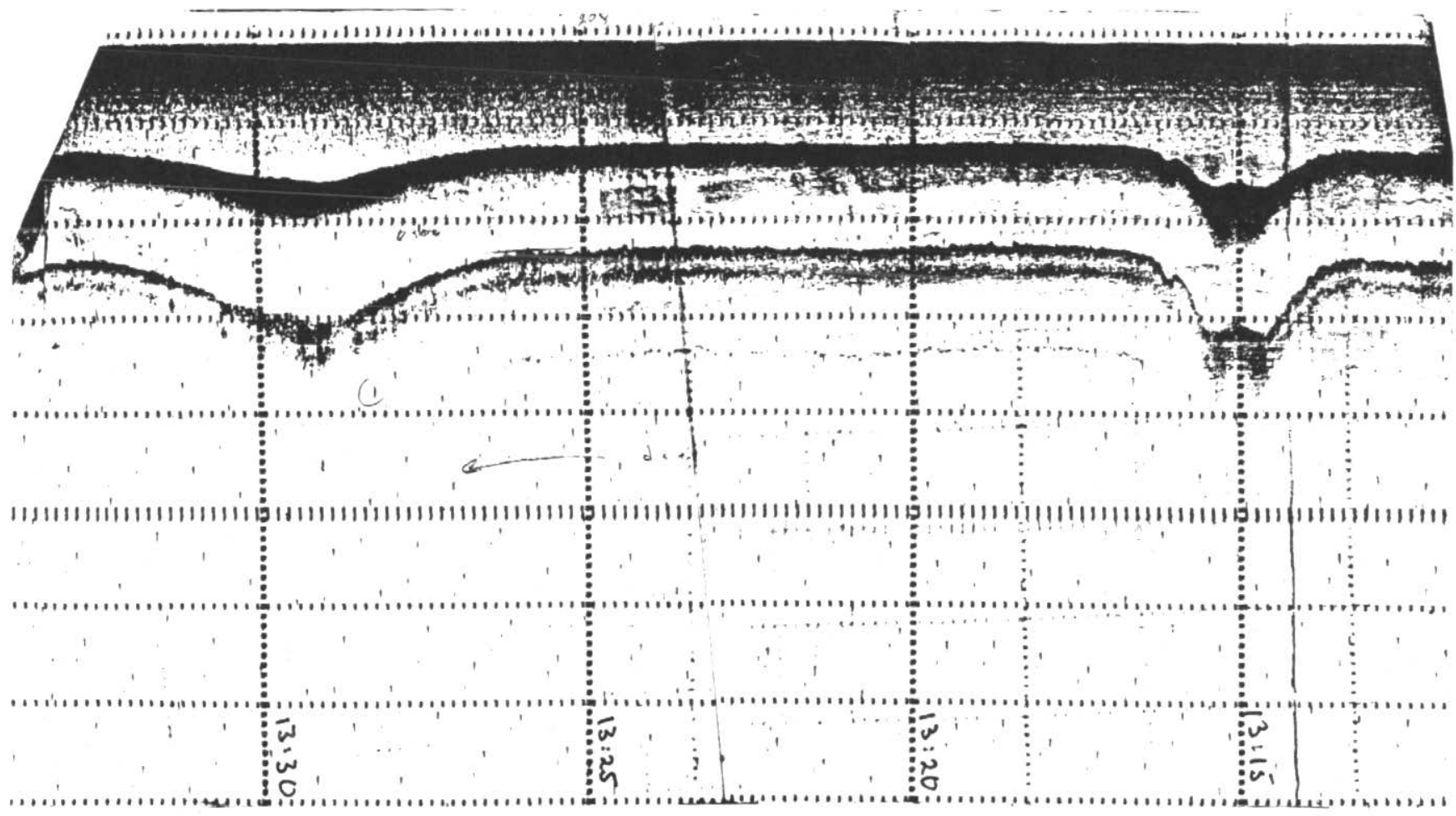

FIG. 38 Collapsed submarine pingos near edge of Beaufort Shelf in $70 \mathrm{~m}$ of water. 


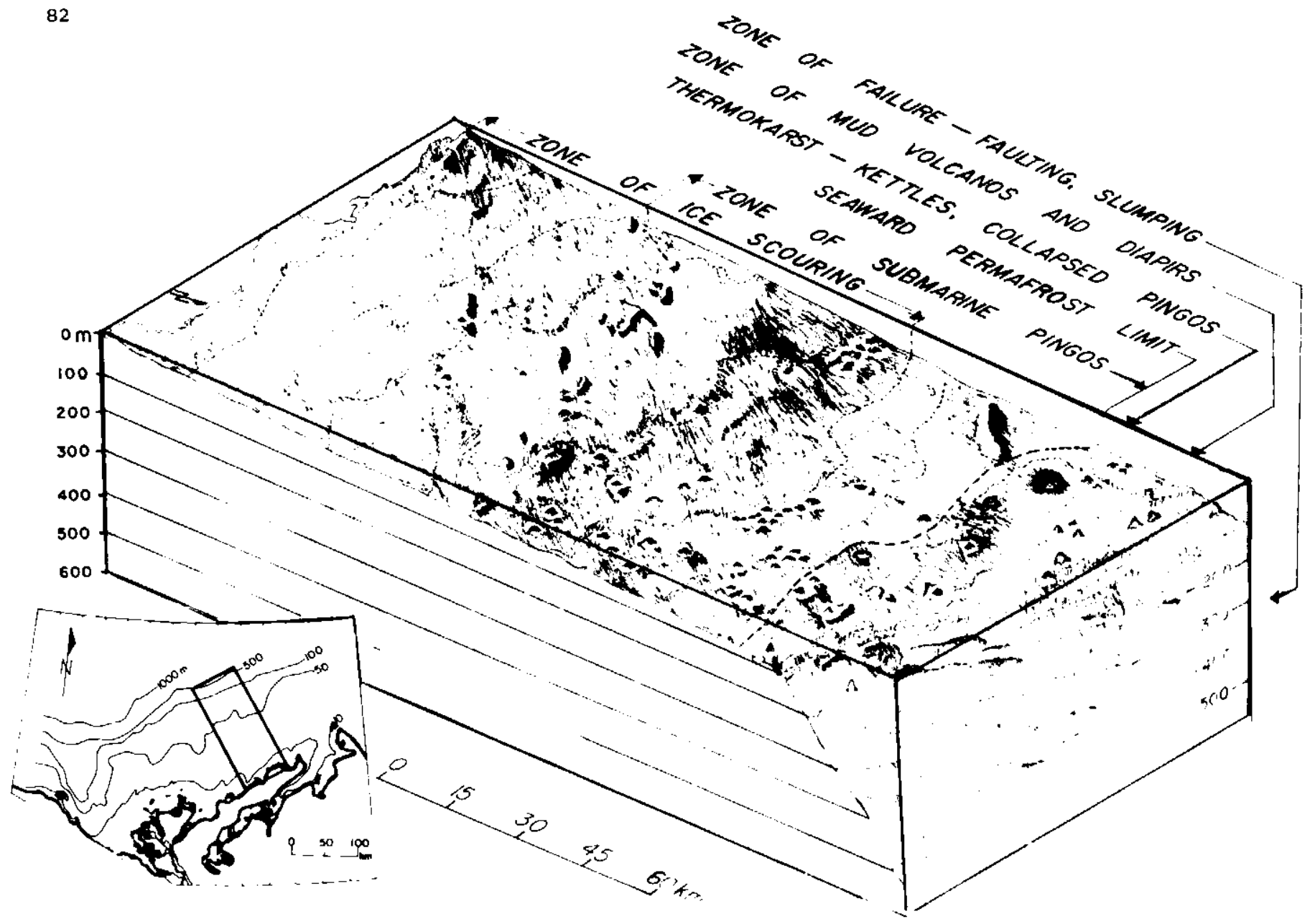

FIG. 39 Schematic diagram of mojor morphological features on Beaufort Shelf north of Tuktoyaktuk Peninsula. Zone of ice-scouring indicated, but details of these features are not shown here. Diagram after author, is based on isometricorthogonal projections of Bathymetry from Canadian Hydrographic Service, D. Monahan (1973).

either seismic or sonic techniques. These surveys are not oriented for routine mapping but are designed more for problem-solving, such as the tunnel feasibility study proposed for Halifax-Dartmouth harbours involving hydrographic and seismic profiling (Grant 1967), or, the multi-disciplinary surveys of Canadian research vessels (Pelletier 1971b), the Canadian coast Guard fleet of Transport Canada, and numerous chartered ships. Yet both methodologies are essential and will ultimately reach a common objective, which is mapping and understanding offshore geology.

Several dominant aspects of the relationship between surficial geology and engineering aspects are readily apparent and may be grouped into a few categories. Although some overlap exists, the main classification is as follows:
1. Erosion and Sedimentation
- current scour and fill
- sand waves
- megaflutes
- ice scour grooves and ridges
- turbidity currents
- sand bars
- buried river channels
2. Morphology
- canyons
- end moraines

- ridges

- valleys

- troughs

- fjords

- scarps

- terraces

- thermokarst

- pingos

- diapirs

- mud volcanoes

- pockmarks

3. Movement

- scarps

- slump features

- hummocky terrain

- bedding dislocation

- faulting

- earthquakes

4. Ground Ice

- ice layers

- ice-bonded sediments

- thermal degradation

5. Sediments

- unstable substrate

- presence of hydrocarbons

- presence of organic material

- presence of clathrates

- hard bottom due to sands and boulders 
- hard bottom due to thin sediment cover

- moraine and drift

- geotechnical properties

It is important to appreciate the advantage of geological maps, cross-sections, and models when attempting engineering profects. Also, many socalled engineering hazards may be benefictal to some other phase of the same enterprise. An appreciation of working with nature is the most ready guide, and this can be realized when the geologist and engineer both have the framework of the enviroment and the model of natural development firmly in their grasp. Once the framework study is completed, the surficial geologist must then provide more information on geotechnical properties by such means as velocity testing of materials, and indicate the extent of the problem and its possible solution. This must be done for the relatively compressed framework of the engineering site. Because the engineering site is commonly fixed and may not be relocated, the geologist must present all information in its truest perspective so that the engineer can complete the project safety and successfully. This is the real challenge and test of geological and engineering practices in the offshore.

\section{ACKNOWLEDGEMENTS}

My thanks are extended to many associates who provided me with much advice and matertal: David Monahan made unpublished Canadian Hydrographic Service material available and reviewed many aspects of hydrographic charting and the Natural Resources Maps for all Canadian waters; B.D. Bornhold gave his material on the Arctic Archipelago and the British Columbia shelf, D.L. Tiffin discussed and gave numerous constructive leads on the geollogical and geophysical framework of the British Columbia continental margin; J.L. Luternauer and J.J. Clague provided material on surficial geology of the Brittsh Columbia coastal zone and inner shelf; and many officers of the Earth Physics Branch, Ottawa, such as D.A. Forsyth, R.J. Wetmiller, J.F. Sweeney, L.W. Sobczak for providing geophysical information for several marine regions of Canada.

Great assistance on information of the marine geology of the eastern seaboard of Canada was provided by the following: L.H. King on the Scotian and adjacent Newfoundland shelf, Gordon Fader working in the Bay of Fundy; C.L. Amos for his material dealing with the northern embranchments of Fundy, such as Minas Basin; G.E Reinson who provided papers and illustrative material on the Miramichi estuary; D.H. Loring and E.H. Owens for their many valuable discussions and donations of investigative material on the Gulf of St. Lawrence; R.H. Fillon, Gustav Vilks and A.C. Grant provided insight on the surficial history of the Labrador shelf and slope; Gustav Vilks and M.A. Rashid for their contributions on the widespread presence of methane gas in surficial sediments, and Rashid for making materials and discussions available on the geotechnical properties of clays containing organic substances - a work carried out with $R$. Brown of Nova Scotia Techntcal College, Halifax; and D.E. Buckley who, over the years, has provided the writer with considerable material and penetrating discussions on numerous aspects of environmental marine geology. The present paper was reviewed by J.S. Scott and J.A.M. Hunter with partial reviews by L.H. King and C.F.M. Lewis. These associates are thanked for their efforts and comenents.

For the past two decades the writer has had continuous advice on high Arctic marine operations, specifically, the Polar Continental Shelf Project and the Canadian Coast Guard. During this time, scientists such as J.I. Marlowe, Gustav vilks, D.E. Buckley and A.C. Grant have added immeasurably to the present paper with their contributions on marine surficial geology. Others have also given aid both materially and intellectually: C.F.M. Lewis, S.M. Blasco, Patrick McLaren, B.D. Bornhold and J.A.M. Hunter for their work and companionship in the Beaufort Sea and eastern Arctic Archipelago: and Brian MacLean and R.H.K. Falconer for their contributions on the Baffin Island continental margin. These acknowledgements for the offshore do not include the enormous contribution of the Canadian petroleum industry.

Professional assistance was given by the photographic and clerical sections of the Geological Survey of Canada in the preparation of this paper. My personal thanks are given to Jane McKee for her many careful drawings and proof-reading of the manuscript. Finally I would like to thank the technical committee for the opportunity to lead off this first national meeting on marine geotechnical engineering for the canadian offshore.

\section{REFERENCES}

Amos, C.L. 1976. Suspended sediment analysis of seawater using Landsat Imagery, Minas Basin, Nova Scotia; in Report of Activities, Part C; Geological survey of Canada, Paper $76-C$, pp. 55-60.

Amos, C.I. 1978. Postglacial evolution of the Minas Basin, Nova Scotia: a sedimentological interpretation; Journal of Sedimentary Pétrology, v. 48(3), pp. 965-982.

Amos, C.L. and Afloldi, T.T. 1979. The determination of suspended sediment concentration in a microtidal system using Landsat data; Journal of Sedimentary Petrology, v. 49 (1).

Amos, C.L. and Asprey, K.W. 1979. Geophysical and sedimentary studies in the Chignecto Bay System, Bay of Fundy - a progress report; Geological Survey of Canada, in Current Research, Paper 79-1B, Part B, Paper no. 27.

Amos, C.L. and Joice, G.H.E. 1977. The sediment budget of the Minas Basin, Bay of Fundy, Nova Scotia; Bedford Institute of Oceanography Data Series.

Amos, C.L. and Long, B.F.N. 1978. The sedimentary character of the Minas Basin, Bay of Fundy; Maritime Sediments, Vol. 14, no. 1, Abstract.

Arctic Petroleum Operators Association 1971. Geological sampling and analytical programBeaufort Sea; APOA Project \#4, compiled by M.M. Lerand, Gulf Oil Canada.

Baker, R.S. and Friedman, G.M. 1973. Sedimentation in an Arctic marine environment: Baffin Bay between Greenland and the Canadian Archipelago; in Earth Science Symposium on Offshore Eastern Canada, P.J. Hood, ed., Geological Survey of Canada, Paper 71-23, pp. 471-498. 
Barret, D.I., Heffler, D.E. and Keen, C.E. 1977. Ocean bottom seismometer developments; in Report of Activities, Part B; Geological Survey of Canada, Raper 77-1B, pp. 129-132.

Blake, W., Jr, and Lewis, C.F.M. 1975. Marine surifical geology: observations in the High Arctic, 1974; in Report of Activities, Part A; Geological Survey of Canada, Paper 75-1A, pp. 383-387.

Blasco, S.M. 1978. Probing with TROV. GEOS, Energy, Mines and Resources Canada, Winter 1978, pp. 13-15.

Bornhold, B.D. 1976. Marine surficial geology: central and eastern Arctic; Report of Activities, Part A, Geological Survey of Canada, Paper 76-1A, pp. 29-31.

Bornhold, B.D. 1975. Suspended matter in the southern Beaufort Sea; Final Report of the Beaufort Sea Profect (Fisheries and Environmental (anada), Study F-4, $30 \mathrm{pp}$.

Bornhold, B.D. 1977. Echo sounding and subbottom profiling in Douglas Channel and Kitimat Arm, British Columbia; in Report of Activities, Part B; Geological Survey of Canada, Paper 77-1B, pp. 265-268.

Bornhold, B.D. 1978. Carbon/Nitrogen (C/N) ratios in surficial marine sediments of British Columbia; in Current Research, Part C; Geological Survey of Canada, Paper 78-1C, p. 108-113.

Bornhold, B.D., Finlayson, N.M. and Monahan, D. 1976. Submerged drainage patterns in Barrow Strait, Canadian Arctic; Canadian Journal of Earth Sciences, v. 13, pp. 305-311.

Bucklety, D.E. 1971. Recent marine sediments of Lancaster Sound, District of Franklin; Maritime Sediments, v. 7, no. 3, pp. 96-117.

Buckley, D.E., Owens, E.H., Schafer, C.T., Vilks, G., Cranston, R.E., Rashid, M.A., Wagner, F.J.E., and Walker, D.A. 1974. Canso Strait and Chedabucto Bay: A multidisciplinary study of the impact of man on the marine environment; in Offshore Geology of Eastern Canada, Volume 1, B.R. Pelletier, ed., Geological survey of Canada, Paper 74-30, pp. 133-160.

Carter, L. 1972. Surficial sediments of Barkely Sound and the adjacent continental shelf, west coast Vancouver Island; Canadian Journal of Earth Sciences, v. 10, no. 4, p. 441.

Chase, R.L. and Tiffin, D.L. 1972. Queen Charlotte fault-zone, British Columbia; in Marine Geology and Geophysics, J.E. Gill, J. Beland and E.W. Mountjoy, eds.; 24th International Geological Congress Proceedings, Section 8 , pp. 17-27.

Chase, R.L. Tiffin, D.L. and Murray, J.W. 1975. The western Canadian continental margin; in Canada's Continental Margins and offshore Petroleum Exploration, C.J. Yorath, E.R. Parker and D.J. Glass, ed.; Canadian Society of Petroleum Geology, Memoir 4, pp. 701-721.

Clague, J.J. 1975a. Quaternary geology, northern Strait of Georgia, British Columbia; in Report of Activities, Part A; Geological Survey of Canada, Paper 75-1, Part A, pp. 397-400.

Clague, J.J. 1975b. Surficial sediments of the northern Strait of Georgia, British Columbia in Report of Activities, Part B; Geological Survey of Canada, Paper 76-1B, pp. 151-156.
Clague, J.J. 1975c. Late Quaternary sea level fluctuations, Pacific coast of Canada and adjacent areas; in Report of Activities, Part C; Geological Survey of Canada, Paper 75-1C, pp. 17-21.

Clague, J.J. 1976. Pleistocene sediments in the northern Strait of Georgia, British Columbia; in Report of Activities, Part B; Geological Survey of Canada, Paper 76-1B, pp. 157-160.

Clague, J.J. 1977. Holocene sediments in northern Strait of Georgia, British Columbia; in Report of Activities, Part A; Geological Survey of Canada, Paper 77-1A, pp. 51-58.

Claque, J.J. 1978. Terrain hazards in the Skeena and Kitimat River Basins, British Columbia; in Report of Activities, Part A; Geological Survey of Canada, Paper 78-1A, pp. 183-188.

Claque, J.J., Gardner, R.H., Ricker, K.E. and Donley, M.W. 1977. Bibliography of Marine Geoscience Information, Pacific Regions of Canada, 1900-1976; Geological Survey of Canada, Paper 77-22, 43 pp.

Clarke, A.H. 1974. Molluscs from Baffin Bay and the northern North Atlantic Ocean; National Museum of Natural Sciences Publication, Biological Oceanography, no. $7,23 \mathrm{pp}$.

Cockbain, A.E. 1963. Distribution of sediments in the continental shelf off the southern British Columbia coast; University of British Columbia Institute of Oceanography, Manuscript Report 15, 7 pp.

Dalrymple, R.W. 1977. Sediment dynamics of macrotidal sand bars, Bay of Fundy; unpublished Ph.D. thesis, McMaster University, Hamilton, Ontario, Canada, $635 \mathrm{pp}$.

Dionne, J.C. 1974. Ou le ler collogue international sur le glaciel (Quebec 20-24 Avril 1974); La Revue de Geographie de Montreal. v. 28 , no. 4 , pp. 461-467.

Drapeau, G. 1970. Sand waves on Browns Bank observed from the SHELF DIVER; Maritime Sediments, v. 6 , pp. 90-101.

Drapeau, G. 1971. The sedimentology of the surficial sediments of the western portion of the Scotian Shelf; Ph.D. Disseration, Dalhousie, University, Halifax, Canada.

Drapeau, G., and king. L.H. 1972. Surficial geology of the Yarmouth-Browns Bank map area; Marine Sciences Branch, Paper 3 and Geological Survey of Canada Paper 72-74, 6 pp.

Environment and Fisheries Canada 1977. An Arctic Atlas: Background information for developing marine oilspill counter measures: produced by Fenco Consultants and Slaney and Associates for the Environmental Impact Control Directorate, Arctic Marine Oilspill Program Report EPS-9-EC-78-1.

Fader, G.B., King, L.H. and MacLean, B. 1977. Surficial geology of the eastern Gulf of Maine and Bay of Fundy; Marine Sciences Branch, Paper 19 and Geological Survey of Canada, Paper 76-17, 23 pp.

Fillon, R.H. 1975. Deglaciation of the Labrador continental shelf; Nature, v. 253, no. 5491, pp. 429-431. 
Fillon, R.H. 1976. Hamilton Bank, Labrador Shelf: Postglacial sediment dymamics and paleooceanography; Marine Geology, v. 20, pp. 7-25.

Fillon, R.H. 1978. Deep shelf and slope terraces off northern Labrador; Nature, v. 273, no. 5665, pp. 743-746.

Filion, R.H., Ferguson, C. and Thomas, F. 1978. Cenozoic provenance and sediment cycling, Hamilton Bank, Labrador Shelf; Journal of Sedimentary Petrology, v. 48, no. 1, pp. 253-268.

Finlayson, N.M. 1976. Natural Resource Map. $1: 250,000$; Canadian Hydrographic Service, Ottawa Canada, maps 26130, 26135, 26140, $26145,26240,26245$.

Fortier, Y.O. and Morley, I.N. 1956, Geological unity of the Arctic Islands: Transactions of the Royal Soctety of Canada, Series 3, pp. 3-12.

Forgeron, F.D. 1959. A preliminary study of Foxe basin bottom sediments; Fisheries Research Board of Canada, Manuscript Report Series no. 45, 41 pp.

Geological Assoctation of Canada 1977. Symposium on the geological and geophysical environment of the Beaufort Sea Proceedings. Annual Meeting, Vancouver, 1973 Abstracts.

Grant, A.C. 1967. A continuous seismic profile from Halifax Harbour, Nova Scotia, Maritime Sediments, v. 13, p. 64 .

Grant, A.C. 1969. Some aspects of the bedrock geology of Hudson Bay as interpreted from continuous seismic reflection profiles; in Earth Science Symposium on Hudson Bay, P.J. Hood, ed., Geological Survey of Canada, Paper 68-53, pp. 136-143.

Grant A.C. 1971a. Distributional trends in the recent marine sediments of northern Baffin Bay; Maritime Sediments, v. 7, no. 2, pp. 41-63.

Grant, A.C. 1971b. Geological and geophysical results bearing upon the structural history of the Flemish Cap Region: in Earth Science Symposium on the Eastern Canadian Offshore P.J. Hood, ed., Geological Survey of Canada, Paper 71-22, pp. 373-388.

Grant, A.C. 1972. The continental margin off Labrador and eastern Newfoundland - morphology and geology; Canadian Journal of Earth Sciences, v. 9, pp. 1394-1430.

Grant, A.C. and Manchester, K.S. 1971. Seismic reflection profile from the continental margin off southern Labrador, Canada; Bedford Institute of Oceanography, Data Series, BI-D-73-9, 3 pp.

Herman, Y. 1974. Marine geology and oceanography of the Arctic seas; Y. Herman, ed., New York, Springer-Verlag, $397 \mathrm{pp}$.

Herzer, R.H. 1978. Submarine canyons and slumps on the continental slope off southern Vancouver Island; in Current Research, Part A; Geological Survey of Canada, Paper 78-1A, pp. 357-360.

Hfulstrom, F. 1935. The morphological activity of rivers as illustrated by Rivers Fyris; Bulletin of Geological Institute, Uppsala, Sweden, v. 25, Chapter III.
Hobson, G.D. and Voyce, J. 1974. Titles and abstracts of scientiflc papers supported by PCSP; Polar Continental Shelf Profect, No. 1. Catalogue No. M78-1 1974, Supply and Services Canada, Ottawa, Canada.

Hobson, G.D. and Voyce, J. 1975. Titles and abstracts of scientific papers supported by PCSP; Polar Continental Shelf Project, No. 2 . Catalogue No. M78-3/1975, Supply and Services Canada, Ottawa, Canada.

Hobson, G.D. and Voyce, J. 1978. Titles and abstracts of scientific papers supported by PCSP; Polar Continental Shelf project, No. 3. Catalogue No. M78-5/1978. Supply and Services Canada, Ottawa, Canada.

Hood, P.J. 1969. Earth science symposium on Hudson Bay: Geological Survey of Canada, Paper 68-53, $385 \mathrm{pp}$.

Hood, P.J. 1973. Earth science symposium on offshore eastern Canada: Geological Survey of Canada, Paper 71-23, 652 pp.

Horn, D.R. 1963. Marine Geology, Peary Channel, District of Franklin (Polar Continental Shelf Profect); Geological Survey of Canada, Paper $63-11,33 \mathrm{pp}$.

Horn, D.R. 1967. Recent marine sediments and submarine topography, Sverdrup Islands, Canadtan Arctic Archipelago. Unpublished Ph.D. thesis, University of Texas, Austin, Texas, $362 \mathrm{pp}$.

Hunter, J.A.M. and Blasco, S.M. 1979. High resolution geophysics in Canada - a review: in Proceedings, First Canadian Conference on Marine Geotechnical Engineering; Calgary, Alberta, Canada; April 1979, pP. 95-124.

Hunter, J.A.M. and Judge, A.S. 1975. Geophysical investigations of sub-sea permafrost in the Canadian Beaufort Sea; Proceedings, Third International Conference on Port and Ocean Engineering under Arctic Conditions; D.C. Burrell and D.W. Hood, eds., Institute of Marine Science, University of Alaska, pp. 1025-1057.

Hunter, J.A.M., Judge, A.S., Macaulay, H.A., Good, R.L., Gagne, R.M. and Burns, R.A. 1976. Permafrost and frozen sub-seabottom materials in the southern Beaufort Sea Bepartment of the Environment, Beaufort Sea Technical Report no. 22, $174 \mathrm{pp}$.

Hunter, J.A.M., Neave, K.G., Macaulay, H.A. and Hobson, G.D. 1978. Interpretation of sub-sea bottom permafrost in the Beaufort Sea by seismic methods, Part 2. Estimating the thickness of the High-Velocity Layer; in Proceedings, Third International Conference on Permafrost, Edmonton, Alberta, Canada; National Research Council of Canada, Vol. 1 , pp. 521-526.

Hunter, J.A.M. , Neave, K.G., Macaulay, H.A. and Hobson, G.D. 1978. Interpretation of subseabottom permafrost in the Beaufort Sea by seismic methods, Part 1 Seismic Refraction Methods; in Proceedings, Third International Conference on Permafrost, Edmonton, Alberta, Canada; National Research Council of Canada, v. 1, pp. 515-520.

Johnston, W.A. 1921. Sedimentation of the Fraser River Delta; Geological Survey of Canada, Memoir 125, 46 pp. 
Kellerhal, P. and Murray, J.W. 1969. Tidal flats at Boundary Bay, Fraser River delta, British Columbia; Bulletin Canadian Petroleum Geology, v. 17, no. 1, pp. 67-91.

Kerr, J.w. 1979. Structural framework of Lancaster Aulacogen, Arctic Canada Geological Survey of Canada. Open File Report 619 (also Bulletin 319 in preparation for 1980, Geological Survey of (anada).

King, L.H. 1967a. Use of a conventional echosounder and textural analyses in delineatina sedimentary facies - Scotian Shelf; Canadian Journal of Earth Science, v.5, pD. 691-708.

King. L.H. 1967b. On the sediment and stratiqraphy of the Scotian Shelf; in Geology of the Atlantic Reqion: Geoloqical Association of Canada, Special Publication no. 4, pp. 71-92.

King, L.H. 1969. Submarine end moraines and associated deposits on the Scotian Shelf, Geoloqical Societv of America Bulletin, v. 80 , pp. 83-96.

King, I.H. 1970a. Surficial geology of the HalifaxSable Island map area; Canadian Department of Enercy, Mines and Resources, Marine Sciences Branch, Paper 1, $16 \mathrm{pp}$.

King, L.H. 1970b. Origin of the outer part of the Laurentian Channel. Canadian Journal of Earth Sciences, v. 7, pp. 1470-1484.

Kinq, L.H. 1976. Relict iceberg furrows on the Laurentian Channel and western Grand Banks; Canadian Journal of Earth Sciences, v. 13, pp. 1082-1092.

King, L.H. 1979. Aspects of regional surficial geology related to site investigation requirements - eastern Canadian Shelf; Preprint International Conference, offshore Site Investigation. The Society for Underwater Technology, London, U.K., 1979, 34 pp.

King, L.H, and Fader, G.B. 1976. Application of the Huntec deep tow high - resolution seismic system to surficial and bedrock studies Grand Banks of Newfoundland; in Report of Activities, Part C; Geological Survey of Canada, Paper 76-1C, pp. 5-7.

King, L.H. and Maclean, B. 1970a. Observations on a Cretaceous outcrop from a submersible Scotian Shelf; Canadian Journal of Earth Sciences, v. 7, no. 1, pp. 188-190.

King, L.H. and Maclean, B. 1970b. Pockmarks on the Scotian Shelf; Geological Society of America Bulletin, v. 81, pp. 3141-3148.

King, L.H. and Maclean, B. 1976. Geology of the Scotian Shelf and adjacent areas; Marine Sciences Branch, Paper 7, and Geological Survey of Canada, Paper 74-31, 31 pp.

King, L.H. and Maclean, B. and Drapeau, G. 1972. The Scotian Shelf Submarine end-moraine complex; in Proceedings 24 th International Geological Congress, Montreal, Canada, 1972, v. 8, pp. 237-249.

King, L.H. and Young, I.F. 1977. Paleocontinental slopes of East Coast Geosyncline (Canadian Atlantic Margin). Canadian Journal of Earth Sciences, v. 14, pp. 2553-2564.

Klein, G. de V. 1970. Depositional and dispersa1 dynamics of intertidal sand bars; Journal of Sedimentary Petrology, v. 40, pp. 1095-1127.

Knight, R.J. 1971. Distributional trends in the Recent marine sediments of Tasiyac Cove of Ekalugad Fiord, Baffin Island, Northwest Territories; Maritime Sediments, v. 7, pp. 1-18.
Knight, R.J. 1977. Sediments, bedforms and hydraulics in a macrotidal environment, Cogequial Bay (Bay of Fundy), Nova Scotia, Ph.D. thesis, McMaster University, Hamilton, Canada, 429 pp.

Kranck, K. 1966. Sediments of Exeter Bay, Baffin Island, District of Franklin; Geological Survey of Canada, Paper 68-8, $60 \mathrm{pp}$.

Kranck, K. 1967. Bedrock and sediments of Kouchibouguac Bay, New Brunswick; Journal of Fisheries Research Board, Canada, v. 24, pp. 2241-2265.

Kranck, K. 1971. Surficial geology of Northumberland Strait; Marine Sciences Branch, Paper 5, and Geological Survey of Canada, Paper 71-53, $10 \mathrm{pp}$.

kranck, K. 1972a. Geomorphological development and post-Pleistocene sea level changes, Northumberland Strait, Maritime provinces; Canadian Journal of Earth Sciences, v. 9, pp. 835-844.

Kranck, K. $1972 \mathrm{~b}$. Tidal control of sediment distribution in Northumberland Strait, Maritime Provinces; Journal of Sedimentary Petrology, v. 42 , pp. 596-601.

Leslie, R.J. 1963. Foraminiferal study of a crosssection of Hudson Bay, Canada; Geological Survey of Canada, Paper 63-16, 25 pp.

Leslie, R.J. 1964. Sedimentology of Hudson Bay, District of Keewatin; Geological Survey of Canada, Paper 63-48, 31 pp.

Leslie, R.J. 1965. Ecology and paleoecology of Hudson Bay foraminifera; Bedford Institute of Oceanography, Report 65-6.

Leslie, R.J. and Pelletier, B.R. I965. Bedrock geology beneath Hudson Bay as interpreted from submarine physiography; Bedford Institute of Oceanography, Report 65-12.

Levy, E.M. 1978. Visual and chemical evidence for a natural seep at Scott Inlet, Baffin Island: in Current Research, Part B, Geological Survey of Canada, Paper 78-1B, Report 4 .

Lewis, C.F.M. 1978. Drift ice scratches the seafloor; GEOS; Energy, Mines and Resources Canada, Summer, 1978, pp. 18-20.

Lewis, C.F.M. (in preparation). Bottom scour by sea lce in Southern Beaufort Sea; Beaufort Sea Project Technical Report no. 23; Fisheries and Environment Canada; Victoria, British Columbia.

Lewis, C.F.M., Blasco, S.M., Bornhold, B.D., Hunter, J.A.M., Judge, A.S., Kerr, W.J., McLaren, P. and Pelletier, B.R. 1977. Marine geological and geophysical activities in Lancaster Sound and adjacent fiords; in Report of Activities, Part A. Geological Survey of Canada, Paper 77-1A, pp. 495-506.

Lewis, C.F.M., Horsman, J.R. and Ross, D.I. 1974. Geological, geophysical and hydrographic studies in Lancaster Sound and Maxwell Bay, District of Franklin; in Report of Activites, Part A; Geological Survey of Canada, Paper 77-1A, pp. 251-2.

Lewis, C.P. and Forbes, D.L. 1975. Coastal sedimentary processes and sediments, southern Canadian Beaufort Sea; Department of the Environment, Beaufort Sea Report no. $24,68 \mathrm{pp}$.

Lфken, O.H. 1973. Bathymetric observations along the east coast of Baffin Island: submarine moraines and iceberg distribution; in Earth Sciences Symposium on Offshore Eastern Canada, P.J. Hood, ed., Geological Survey of Canada, Paper 71-23, pp. 509-519. 
Loken, O.H. and Hodgson, D.A. 1971. On the submarine geomorphology along the east coast of Baffin Island, Canadian Journal of Earth Sciences, v. 8, pp. 185-195.

Loncarevic, B.D. and Falconer, R.K.H. 1977. An oil slick occurrence off Baffin Island: in Report of Activities, Part A, Geological Survey of Canada, Paper 77-1A, pp. 523-524.

Long, B.F.N. 1978. Determination of sediment transport rate in the Minas Basin, Nova Scotia: preliminary results of the first tracer experiment using radioisotope: in Report of Activities, Part B, Geological Survey of Canada, Paper 77-1B, pp. 85-92.

Long, B.F.N, and Belanger, J.R. 1978. Bedform studies by remote sensing balloon technique in Minas Basin, Bay of Fundy; Current Research Part A; Geological Survey of Canada, Paper 78-IA, pp. 503-508.

Loring, D.H. 1962. A preliminary study of the soft sediment layers in the Gulf of st. Lawrence and parts of the Scotian and Newfoundland Shelves; Fisheries Research Board of Canada, Manuscript Report Series no. 107, pp. $1-17$.

Loring, D.H. 1965. Resume of marine geological investigations carried out by the Atlantic Oceanographic Group in the Gulf of St. Lawrence, 1961-64; Maritime Sediments, v. 1, pp. 8-9.

Loring, D.H. 1967. Resume of geological investigations by the Atlantic Oceanographic Group; Maritime Sediments, v. 3, pp. 24-26.

Loring, D.H. 1972. Late Pleistocene glaciomarine sedimentation and glacial re-advances in the Laurentian trough, Gulf of St. Lawrence, Proceedings 24th Internation Geological Congress, Montreal, Canada, Section 10, PP. 305.

Loring, D.H. 1975. Surficial geology of the Gulf of St. Lawrence; in Jffshore Geology of eastern Canada; W.J. van der Linden and J.A. Wade, eds.. Geological Survey of Canada, Paper 74-30, volume 2, pp. 11-34.

Loring, D.H. and Nota, D.J.G. 1966. Seafloor conditions around the Magdalen Islands in the southern Gulf of St. Lawrence; Journal of Fisheries Research Board of Canada, v. 23, pp. 1197-1207.

Loring, D.H. and Nota, D.J.G. 1968. Occurrence and stgntficance of iron, manganese and titanium in glacial marine sediments from the estuary of the St. Lawrence River; Journal of Fisheries Research Board of Canada, v. 25, pp. 2327-2347.

Loring, D.H. and Nota, D.J.G. 1973. Morphology and sediments of the Gulf of St. Lawrence; La Revue de Geographie de Montreal, v. 23, p. 2327-2347.

Loring, D.H., Nota, D.J.G., Chesterman, W.D. and Wong, H.K. 1970. Sedimentary envi ronments on the Magdalen Shelf, southern Gulf of st. Lawrence; Marine Geology, v. 8, pp. 337-354.

Luternauer, J.L. 1972. Patterns of sedimentation in Queen Charlotte Sound, British Columbia. unpublished Ph.D. thesis, University of British Columbia, Vancouver.

Luternauer, J.L. 1975a. Fraser delta sedimentation, Vancouver, British Columbia; in Report of Activities, Part A; Geological Survey of Canada, Paper 75-1A, pp. 467-468.
Luternauer, J.L. 1975b. Fraser delta sedimentation, Vancouver, British Columbia; in Report of Activities, Part B; Geological Survey of Canada, Paper 75-1B, pp. 171-172.

Luternauer, J.L. 1976a. Fraser delta sedimentation, Vancouver, British Columbia; in Report of Activities, Part A; Geological Survey of Canada, Paper 76-1A, pp. 213-219.

Luternauer, J.L. 1976b. Skeena delta sedimentation, British Columbia; in Report of Activities, Part A; Geological Survey of Canada, Paper 76-1A, pp. 239-242.

Luternauer, J.L. 1976c. Fraser delta sedimentation, Vancouver, British Columbia; in Report of Activities, Part B; Geological Survey of Canada, Paper 76-1B, pp. 169-171.

Luternauer, J.L. 1976d. Geofisheries research off the west coast of Canada; in Report of Activities, Part C; Geological Survey of Canada, Paper 76-1C, pp. 157-159.

Luternauer, J.L. 1977. Fraser delta sedimentation; in Report of Activities, Part A; Geological Survey of Canada, Paper 77-1A, pp. 65-72.

Luternauer, J.L., Linden, R.H. and Thomason, R.E. 1978. Applications of side-scan sonar to geoenvironmental research in the coastal waters of British Columbia; in Current Research Part B; Geological Survey of Canada, Paper 78-1B, pp. 181-186.

Luternauer, J.I. and Murray, J.W. 1969. Sediments of Queen Charlotte Sound, British Columbia; in Report of Activities, Part A; Geological Survey of Canada, Paper 69-1A, pp. 8-11.

Luternauer, J.L. and Murray, J.W. 1970. Sediments of Queen Charlotte Sound, British Columbia; in Report of Activities, Part A; Geological Survey of Canada, Paper 70-1A, p. 28.

Luternauer, J.L. and Murray, J.W. 1973. Sedimentation on the western delta front of the Fraser River, British Columbia; Canadian Journal of Earth Sciences, v. 10, no. 11, pp. 1642-1663.

Luternauer, J.L. and Swan, D. 1978. Kitimat submarine slump deposit(s); A preliminary report, in Report of Activities, Part A; Geological Survey of Canada, Paper 78-1A, pp. 327-332.

Luternauer, J.L., Swan, D. and Linden, R.H. 1978. Sand waves on the southeastern slope of Roberts' Banks; in Report of Activities, Part A; Geological Survey of Canada, Paper 78-1A, pp. 351-356.

Maclean, B. 1978. Marine geological-geophysical investigations in 1977 of the Scott Inlet and Cape Dyer-Frobisher Bay areas of the Baffin Island continental shelf: in Current Research, Part B, Geological Survey of Canada, Paper 78-1B, pp. 13-20.

Maclean, B., Fader, G.B. and King, L.H. 1977. Surftcial geology of Canso Bank and adjacent areas; Marine Sciences Branch, Paper 20, and Geological Survey of Canada, Paper 76-15. $11 \mathrm{pp}$.

Maclean, G. and Falconer, R.K.H. 1977. Baffin Island Shelf - shallow corehole drilling, 1976; in Report of Activities, Part B, Geological Survey of Canada, Paper 77-1B, pp. 125-127.

Maclean, B., Jansa, L.F., Falconer, R.K.H., and Srivastava, S.P. 1977. Ordovician Strata on the southeastern Baffin Island Shelf revealed by shallow drilling: Canadian Journal of Earth Sciences, v. 14, pp. 1925-1939. 
Maclean, B. and King, L.H. 1971. Surficial geology of the Banquereau and Misaine Bank map area; Marine Sciences Branch, Paper 3, and Geological Survey of Canada, Paper 71-52.

Manmerick, X.J. and Taylor, I.L. 1971. Bathymetry of the Pioneer survey area north of $45^{\circ}$ latitude, Scripps Institute of Oceanography, California; Geological Data Center, Special Chart no. 1.

McLaren, P. 1975. Under-ice diving operations in the coastal environments of southeast MeIville and western Byam Martin Islands, in Report of Activities, Part A; Geological Survey of Canada, Paper 75-1, pp. 475-477.

McLaren, P. 1979. The coastal geomorphology, sedimentology and processes of eastern Melville and western Byam Martin Islands, Canadian Arctic Archipelago; Geological Survey of Canada Bulletin (in press).

McCann, S.B. ed. (in preparation). First national conference on the coastlines of Canada; abstracts in Maritime Sediments, v. 14, no. I (1978); papers in Geological Survey of Canada Paper.

MCManus, D.A. 1963. Bathymetric compilation between latitude $40^{\circ}$ and $51^{\circ} \mathrm{N}$, and longitude $124^{\circ}$ and $132^{\circ} \mathrm{W}$ (Northeast Pacific) Department of University of Washington.

McMillan, N.J. 1973. Shelves of Labrador Sea and Baffin Bay, Canada: in Future Petroleum Provinces of Canada, R.G. McCrossan, ed., Canadian Society of Petroleum Geologists, Memoir 1, Pp. 473-517.

Marlowe, J.I. 1964. Marine geology, the western part of Prince Gustaf Adolf Sea; Bedford Institute of Oceanography, Report 64-9.

Marlowe, J.I. 1965. Sedimentology of the Prince Gustaf Adolf Sea, District of Franklin Bedford Institute of Oceanography, Report 65-15.

Marlowe, J.I. 1966. Mineralogy as an indicator of long-term current fluctuations in Baffin Bay; Journal of Sedimentary Petrology, v. 38 , pp. 1065-1078.

Marlowe, J.I. 1967. The geology of part of the continental slope near Sable Island, Nova Scotia; Geological Survey of Canada, Paper $65-38,30 \mathrm{pp}$.

Marlowe, J.I. 1968. Unconsolidated marine sediments in Baffin Bay; Journal of Sedimentary Petrology, v. 35, pp. 1065-1078.

Marlowe, J.I. 1969. A succession of Tertiary Strata off Nova Scotia as determined by dredging; Canadian Journal of Earth Sciences, v. 6, pp. 1077-1094.

Marlowe, J.I. and Vilks, G. 1963. Marine geology, eastern part of Prince Gustaf Adolf Sea, District of Franklin; Polar Continental Shelf Project; Geological Survey of Canada, Paper 63-22, pp. 1-23.

Mathews, W.H. and Shepard, F.P. 1962. Sedimentation of Fraser River Delta, British Columbia; American Association of Petroleum Geologists, Bulletin, v. 46, no. 8, pp. 1416-1438.

Milliman, J.D. L976. Sand and gravel deposits off southwestern Vancouver Island, British Columbia; in Report of Activities, Part A; Geological Survey of Canada, Paper 75-1A, pp. 23-26.

Milne, A.R. and Smiley, B.D. 1978. Offshore drilling in Lancaster Sound; possible environmental. hazards, Institute of Ocean Sciences, Department of Fisheries and the Environment, Sidney, British Columbia, $95 \mathrm{pp}$.

Milne, W.G., Rogers, G.C., Riddihough, G.A., McMechan, G.A. and Hyndman, R.D. 1978. Seismlcity of Western Canada; Canadian Journal of Earth Sciences, v. 15, no. 7, pp. 1170-1193.

Monahan, D. 1971. Three dimensional representation of submarine relief: continental margin of eastern North America: Marine Sciences Branch Paper 9, $10 \mathrm{pp}$.

Monahan, D. 1973. Natural resource Map; 1:250 000; Canadian Hydrographic Service, Ottawa, Canada. Maps 23092, 23096, 26508, 26602, 26606.

Monahan, D. 1977. Natural resources map, 1:250 000; Canadian Hydrographic Service, Ottawa, Canada; Map 15783, 15792, 15794, 19304, 19306.

Monahan, D. and Macnab, R.F. 1975. Macro- and mesomorphology of Flemish Cap, Flemish Pass, and the northeastern Grand Banks of Newfoundland; in Offshore Geology of Eastern Canada; W.J.M. van der Linden, and J.A. Wade, eds., Geological Survey of Canada, Paper 74-30, v. 2, pp. 209-216.

Murray, J.W. and Tiffin, D.L. 1969. Structure of the continental margin west of Vancouver Island, British Columbia; Geological Survey of Canada, Paper 69-1A, pp. 14.

Murray, J.W., MacDonald, R.D., and Tiffin, D.D. 1971. Continental shelf and slope studies, northwestern Vancouver Island, British Columbia; in Report of Activities, Part A; Geological Survey of Canada, Paper 71-1A, pp. 251-254.

Murray, J.W. and Tiffin, D.L. 1969. Structure of the continental margin west of Vancouver Island, British Columbia; Geological Survey of Canada, Paper 69-1A, pp. 14.

Neave, K.G., Judge, A.S., Hunter, J.A.M. and MacAulay, R.H. 1978. Offshore permafrost distribution in the Beaufort Sea as determined from temperature and seismic observations; in Current Research, Part A; Geological Survey of Canada, Paper 78-1A, pp. 13-18.

Nolan, F.J. 1963. Heavy mineral analysis of the beach sands of Nova Scotia. M.Sc. thesis, Dalhousie University, Halifax, Canada, $131 \mathrm{pp}$.

Nota, D.J.G. and Loring, D.H. 1964. Recent depositional condltions in the St. Lawrence River and Gulf - A reconnaissance survey; Marine Geology, v. 2, pp. 198-235.

O'Connor, M.J., MacLeod, N.R. and Blasco, S.M. 1979. Some characteristics of the surficial sediments in the Mackenzie delta region of the southern Beaufort Sea; in Proceedings, First Canadian Conference on Marine Geotechnical Engineering; Calgary, Alberta, Canada, April 1979.

Owens, E.H. 1974. A framework for the definition of coastal environments in the southern Gulf of St. Lawrence; in Offshore Geology of Eastern Canada, volume I, B.R. Pelletier ed., Geological Survey of Canada, Paper 74-30, pp. 47-76.

Patton, G. 1976. Estuarine sedimentary dynamics in the Minas Basin, Bay of Fundy, Nova Scotia; in Report of Activities, Part B; Geological Survey of Canada, Paper 76-1B, pp. 25-29.

Pelletier, B.R. 1960. Submarine geology programe, Polax Continental Shelf Project, Isaachsen, Northwest Territories, Department of Energy, Mines and Resources (Polar Continental Shelf Project), Paper no. 36, 5 pp. 
Pelletier, B.R. 1961. Polar Continental Shelf Project, Western Queen Elizabeth Islands, District of Franklin, 1961; Geological Survey of Canada, unpublished Topical Report no. 47, 8 pp.

Pelletier, B.R. 1962. Submarine geology program, Polar Continental Shelf Profect, Isachsen, District of Franklin; Geological Survey of Canada, Paper 61-21.

Pelletier, B.R. 1966a. Development of submarine physiography in the Canadian Arctic and its relation to crustal movements: in Symposium on Continental Drift, G.v. Garland, ed.. Royal Society of Canada, Special Publications no. 9, p. 77-101.

Pelletier, B.R. 1966b. Bathymetry and geology of Canadian Arctic Archipelago and Baffin Bay in Encyclopedia of Earth Sciences, ed. Rhodes Fairbridge; Rheinhold Publishing Company, v. I, Pp. 160-167.

Pelletier, B.R. 1966c. Bathymetry and geology of Hudson Bay and Approaches; in Encyclopedia of Earth Sclences; Rhodes Fairbridge, ed., Rheinhold Publishing Company, v. 1, pp. 359363.

Pelletier, B.R. 1967. Sedimentation in Arctic waters of the western Queen Elizabeth Islands; Distrlct of Franklin, Canada; Maritime Sediments, v. 3, no. 4, pp. 90-99.

Pelletier, B.R. 1968. The submersible PISCES feasibility study in the Canadian Arctic; Maritime Sediments, v. 4, no. 2, pp. 69-72.

Pelletier, B.R. 1969. Submarine physiography, bottom sediments, and models of sediment transport: in Hudson Bay; in Earth Science Symposium on Budson Bay, P.J. Hood, ed., Geological Survey of Canada, Paper 68-53, p. 100-135.

Pelletier, B.R. 1970. Sedimentological sampling and results from the diver-lockout SHELF DIVER, Bay of Fundy, Nova Scotia; Maritime Sediments, v. 6 , no. 3, pp. 100-109.

Pelletier, B.R. 1971a. A granodioritic drill core from the Flemish Cap, Eastern Canadian continental margin: Canadian Journal of Earth Sciences; Vol. 8, No. 11, pp. 1499-1503.

Pelletier, B.R. 1971b. Earth Sciences studies in Arctic Marine Waters, 1970; Bedford Institute Biennial Review 1969/70, Ocean Sciences Review, pp. 11-24.

Pelletier, B.R. 1972. Marine Geology in Canada; Earth Science Revlew, H.A.K. Charlesworth, ed., Elsevier Publishing Company, pp. 150-152.

Pelletier, B.R. 1974, Sedimentary textures and relative entropy, and their relationship to the hydrodynamic environment, Bay of Fundy, in Offshore Geology of Eastern Canada, v, 1, B.R. Pelletier, ed., Geological survey of Canada, Paper 74-30, pp. 77-95.

Pelletier, B.R. 1975. Sediment dispersal in the southern Beaufort Sea; Beaufort Sea Project, Environment Canada; Beaufort Sea Technical Report No. $25 \mathrm{a}, 80 \mathrm{pp}$.

Pelletler, B.R., Blasco, S.M. and Lewis, C.F.M. A working hypothesis on the evolution of the Beaufort Shelf morphology (in preparation).

Pelletier, B.R. and Shearer, J.M. 1972. Sea bottom scouring in the Beaufort Sea of the Arctic Ocean; in Proceedings of the 24 th International Geological Congress, Montreal, 1972, Section 8, pp. 251-261.
Pelletier, B.R., Ross, D.I., Keen, C.E. and Keen, M.J. 1975. Geology and Geophysics of Baffin Bay, in Offshore Geology of Eastern Canada, vol. 2. Regional Geology, W.J. van der Linden and J.A. Wade, eds., Geological Survey of Canada, Paper 74-30, p. 247-258.

Pelletier, B.R., Wagner, F.J.E. and Grant, A.C. 1968. Marine geology; in Science, History and Hudson Bay; C.S. Beales, ed., Canada Department of Energy, Mines and Resources, v. 2, Chapter 9, Part III, pp. 557-613.

Perry, R.B. 1961. A study of the marine sediments of the Canadian eastern Arctic Archipelago; Fisheries Research Board of Canada, Manuscript Report Series, no. 89, 80 pp.

Pharo, C.H. 1972. Sediments of the central and southern Strait of Georgia, British Columbia; Ph.D. thesis, University of British Columbia, Vancouver, British Columbia, $290 \mathrm{pp}$.

Rharo, C.H. and Barnes, W.C. 1976. Distribution of surficial sediments of the central and southern Strait of Georgia, British Columbia; Canadian Journal of Earth Sciences, v. 13, no. 5, pp. 684-696.

Piper, D.J.W. 1974. A late Quaternary stratigraphic marker in the central basin of Baffin Bay; Maritime Sediments, v. 9, pp. 62-63.

Piper, D.J.W. 1975. Late Quaternary deep water sedimentation off Nova Scotia and the western Grand Banks; Canadian Society of Petroleum Geologists, Memoir 4, pp. 267-272.

Rashid, M.A. and Brown, J.D. 1975. Influence of marine organic compounds on the engineering properties of a remounded sediment; Engineering Geology, v. 9, pp. 141-154.

Reed, J.C. and Sater, J.E. 1974. The coast and shelf of the Beaufort Sea. Proceeding of a symposium on Beaufort Sea coast and Shelf Research, Arctic Institute of North America, $750 \mathrm{pp}$.

Reimnitz, E.R.K, and Maurer, D.K. 1978. Stamukhi shoals of the Arctic - some observations from the Beaufort Sea; United States Geological Survey, Open-file report no. $78-666,16 \mathrm{pp}$.

Reinson, G.E. 1976a. Surficial sediment distribution in the Miramichi estuary, New Brunswick; in Report of Activities, Part C; Geological Survey of Canada, Paper 76-1C, pp. 41-44.

Reinson, G.E. 1976b. Channel and shoal morphology in the entrance to the Miramichi estuary, New Brunswick; in Report of Activities, Part C; Geological Survey of Canada, Paper 76-1C, pp. 33-35.

Reinson, G.E. 1977. Examination of bedforms in shallow water using side-scan sonar, Miramichi estuary, New Brunswick; in Report of Activities, Part B; Geological Survey of Canada, Paper 1977-1B, p. 99-105.

Richards, A.F. and Matlock, H. 1978. Present and recommended U.S. government research in seafloor engineering; Office of Ocean Engineering, National Oceanic and Atmospheric Administration, United States Department of Commerce, $93 \mathrm{pp}$.

Ricker, K.E. 1974. Inventory of marine surficial geology, sedimentology, geomorphology, quaternary paleoecology, geochemistry and related studies of the Pacific shelf of Canada; Part I; Coastal areas of British Columbia, Washington and Alaska; Geological Survey of Canada, Open File no. 197. 
Ricker, K.E. 1975. Inventory of marine surficial geology, sedimentology, geomorphology, Quaternary paleoecology, geochemistry, and related studies of the Pacific regions of Canada; Part I; Coastal zone of British Columbia and adjacent waters off Washington and southeast Alaska; Part II: Continental rise and abyssal regions of the northeast Pacific Ocean; Geological Survey of Canada, Open File no. 276.

Ruffman, A., Meagher, L. and Stewart, J. MCG. 1978. Sable Island sand waves and related shore processes; Maritime Sediments, v. 14, p. 35 Abstract and in Proceedings First National Conference on the coastilines of Canada (see McMann, B.).

Sanford, B.V. and Grand, G.M. 1977. Physiography Eastern Canada and adjacent areas; Geological Survey of Canada, Map 1399A in four sheets, I: 2000000 .

Sater, J.E. 1963. The Arctic Basin: The Arctic Basin: The Arctic Institute of North America, $319 \mathrm{pp}$.

Shearer, J.M. 1971. Preliminary interpretation of shallow seismic reflection profiles from the west side of Mackenzie Bay, Beaufort Sea; in Report of Activities, Part B; Geological Survey of Canada, Paper 7I-1B, pp. 131138.

Shearer, J.M. 1973. Bedrock and surficial geology of the northern Gulf of $s t$. Lawrence as interpreted from continuous seismic reflection profiles; in Earth Science Symposium on offshore Eastern Canada, Geological Survey of Canada, Paper 71-23, pp. 285-303.

Shearer, J.M. and Blasco, S.M. 1975. Further observations of the scouring phenomena in the Beaufort Sea; in Report of Activities, Part A; Geological Survey of Canada, Paper 75-1, pp. 483-49I.

Shearer, J.M., MacNab, R.F., Pelletier, B.R., and Smith, T.B. 1971. Submarine pingos in the Beaufort Sea; Science, v. 174, pp. 816-818.

Shouldice, D.H. 1971. Geology of the western Canadian continental shelf; Canadian Petroleum Geology Bulletin, v. 19, PP. 405-436.

Srivastava, S.P., Baret, D.L., Keen, C.E., Manchester, K.S., Shih, K.G., Tiffin, D.L., and Lister, C.R.B. 1971. Preliminary analysis of geophysical measurements north of Juan de Fuca Ridge; Canadian Journal of Earth Sclences, v. 8, no. 10, pp. 1265-1281.

Srivastava, S.P. 1973. Interpretation of gravity and magnetic measurements across the continental margin of British Columbia; Canadian Journal of Earth Sciences, v. 10, no. 11, pp. 1664-1677.

Stow, D.A.V. 1978. Regional review of the Nova Scotian outer margin; Maritime Sediments, $v$. 14, no. 1, pp. 17-32.

Swan, D. and Luternauer, J.L. 1978. Mosaic of side scan sonar records, northern Kitimat Arm, British Columbia; Geological Survey of Canada, Open File no. 579.

Swan, D. 1979. Large submarine landslide, Kitimat Arm, B.C., in Proceedings, First Canadian Conference on Marine Geotechnical Engineering; Calgary, Alberta, Canada, April 1979, pp. I31139 .
Swift, D.J.P., Cok, A.E., and Lyall, A.K. 1966. A sub-tidal sand body in the Minas Channel eastern Bay of Fundy, Maritime Sediments, $v$. 2, pp. 175-180.

Swift, D.J.P. and McMullen, R.M. 1968. Preliminary report on intertidal sand bodies in the Minas Basin, Bay of Fundy; Canadian Journal of Earth Sciences, v. 5, pp. 175-183.

Swift, D.J.P., McMullen, R.M. and Lyall, A.K. 1967. A tidal delta with an ebb-flood channel system in the Minas Basin; Maritime Sediments, v. 3, pp. 12-16.

Swift, D.J.P., Pelletier, B.R., Lyall, A.K. and Miller, J.A. 1969. Sediments of the Bay of Fundy - A preliminary report; Maritime Sediments, v. 5, pp. 95-100.

Swift, D.J.P., Pelletier, B.R., Lyall, A.K, and Miller, J.A. 1973. Quaternary sedimentation in the Bay of Fundy; in Earth Science Symposium on offshore Eastern Canada; Geological Survey of Canada, Paper 71-23, pp. 113-151.

Taylor, R.B. and Lewis, C.F.M. 1975. Nearshore marine geological reconnaissance at Cuningham Inlet, Somerset Island, N.W.T., in Report of Activities, Geological Survey of Canada, Paper 75-1, Part A, pp. 505-507.

Tiffin, D.L. 1969. Continuous seismic reflection profiling in the strait of Georgia, British Columbia; unpublished Ph.D. thesis, University of British Columbia, Vancouver, Canada.

Tiffin, D.L. 1972a. Continuous seismic profiles in Tofino Basin, west coast Vancouver Island, British Columbia, survey work 1968; Geological Survey of Canada, Open File 83.

Tiffin, D.L. 1972b. Geological and geophysical studies on the Pacific continental margin and Beaufort Sea; in Report of Activities, Part A; Geological Survey of Canada, Paper 73-IA, pp. 19-20.

Tiffin, D.L. 1973. Continuous reflection seismic profiling data from continental margin west of British Columbia; Geological Survey of Canada, Open File 153.

Tiffin, D.L. 1974. Marine geophysical and geological studies on the Pacific margin; in Report of Activities, Part A; Geological Survey of Canada, Paper 7.4-IA, p. 127.

Ttefin, D.L., Bornhold, B.D., Yorath, C.J., Herzer, R.H. and Taylor, G.C. 1978. Bottom sediments - vicinity of Juan de Fuca and Explorer Ridges, northeast Pacific Ocean; in Current Research, Part A; Geological Survey of Canada, Paper 78-1A, pp. 533-537.

Tiffin,D.L. and Cameron, B.E.B. 1972. Tectonics and depositional history of the continental margin off Vancouver Island, British Columbia; Canadian Journal of Earth Sciences, v. 9, pp. 280-296.

Tiffin, D.L. and Clague, J.J. 1976. Continuous reflection seismic profiling data from strait of Georgia, British Columbia (NTS 92F); Geological Survey of Canada, Open File 394.

Tiffin, D.L. and Murray, J.W. 1966. Mapping offshore shelf with continuous seismic; Oilweek, v. 17 , no. 38, p. $40,50-51$.

Tiffin, D.L., Murray, J.W., Mayers, I.R. and Garrison, R.E. 1971. Structure and origin of foreslope hills, Fraser Delta, British Columbia; Bulletin, Canadian Petroleum Geology. v. 19, no. 3, pp. 589-600. 
Tiffin, D.L. and Seemann, D. 1975. Bathymetric map of the continental shelf, slope and ocean basin off western Canada; Geological Survey of Canada, Open File 301.

Van der Linden, W.J., Fillon, R.H, and Monahan, D.I. 1976. Hamilton Bank, Labrador margin: origin and evolution of a glaciated shelf: Marine Sciences Branch Paper 14 and Geological Survey of Canada Paper 75-40, 31 pp.

Vilks, G. 1964. Bottom sediment and foraminifera study of East Bay, Mackenzie King Island, (Polar Continental Shelf Project); Geological Survey of Canada; Paper 64-53, 26 pp.

Vilks, G. 1972. Plnaktonic foraminifera in the water and sediments of Beaufort Sea, Canadian Arctic; in proceedings of 24 th International Geological Congress, Montreal, Canada; Section 8, p. 135-141.

Vilks, G. and Mudie, P.J. 1978. Early deglaciation of the Labrador Shelf; Science, v. 202, p. 1181-1183.

Vilks, G. and Rashid, M.A. 1977. Methane in the sediments of a subarctic continental shelf; Geoscience Canada, v. 4, no. 4, p. 191-197.

Vilks, G., Wagner, F.J.E., and Pelletier, B.R. 1979. The Holocene marine environment of the Beaufort Sea; Geological Survey of Canada, Bulletin $303,43 \mathrm{pp}$.

Wagner, F.J.E. 1969. Faunal study, Hudson Bay and Tyrrell Sea; in Earth Science Symposium on Hudson Bay, P.J. Hood; ed., Geological Survey of Canada, Paper 68-53, pp. 7-48.

Wahlgren, R.V. 1979a. Ice-scour tracks on the Beaufort Sea continental shelf - their form and an interpretation of the processes creating them; Unpublished M.A. thesis, Carleton University, Ottawa, Ontario, Canada 2 vols. $424 \mathrm{pp}$.

Wahlgren, R.V. 1979b. Ice-scour tracks in eastern Mackenzie Bay and north of Pullen Island,
Beaufort Sea; in Current Research, Part B; Geological Survey of the Canada, Paper 79-1B, Report No. 9.

Wahlgren, R.V. and Lewis, C.F.M. 1977. Estimation of bulk density and water content of Beaufort Sea sediment cores using $X$-radiographs; in Report of Activities, Part A; Geological Survey of Canada, Paper 77-1A, pp. 465-470.

Waldichuck, M. 1953. Oceanography of the Strait of Georgia. III. Character of the bottom; Fisheries Research Board of Canada, Progress Reports of the Pacific Coast Stations, no. 95 , pp. 59-63.

Wetmiller, R.J. and Forsyth, D.A. 1978. Seismicity of the Arctic, 1908-1975; in Arctic Geophysical Review, J.F. Sweeney, ed., Earth Physics Branch, v. 45, no. 4, pp. 15-24.

Wise, P. 1971. Textural study of sediments of Barrow Strait - District of Franklin; Maritime Sediments, v.7. n. 3., pp. 126-137.

Yorath, C.J., Bornhold, B.D. and Thomason, R.E. 1979. Oscillation ripples on the northeast Pacific continental shelf; Marine Geology, v. 31, pp. 45-58.

Yorath, C.J., Currie, R.G., Tiffin, D.L., and Cameron, B.E. 1978. Submersible operations on the Canadian Pacific continental margin, Report II; in Current Research, Part A; Geological Survey of Canada, Paper 78-1A, Pp. 344-349.

Yorath, C.J., Tiffin, D.L. and Cameron, R.B. 1977. Submersible operations on the Pacific continental margin; in Report of Activities, Part A; Geological Survey of Canada, Paper 77-1A, pp. 301-310.

Young, I.F. and Chase, R.L. 1977. Marine geologicalgeophysical study: southwestern Hecate Strait, British Columbia; in Report of Activites, Part A; Geological Survey of Canada, Paper 77-1A, pp. 315-318. 